\title{
A Political Economy of Contemporary Border Security Walls \\ by
}

Samantha Ponting

A thesis submitted to the Faculty of Graduate and Postdoctoral Affairs in partial fulfillment of the requirements for the degree of

Master of Arts

in

Political Economy

Carleton University

Ottawa, Ontario

(C) 2012 Samantha Ponting 
Library and Archives

Canada

Published Heritage

Branch

395 Wellington Street

Ottawa ON K1A ON4

Canada
Bibliothèque et

Archives Canada

Direction du

Patrimoine de l'édition

395 , rue Wellington

Ottawa ON K1A ON4

Canada
Your file Votre référence

ISBN: 978-0-494-93622-1

Our file Notre référence

ISBN: 978-0-494-93622-1
NOTICE:

The author has granted a nonexclusive license allowing Library and Archives Canada to reproduce, publish, archive, preserve, conserve, communicate to the public by telecommunication or on the Internet, loan, distrbute and sell theses worldwide, for commercial or noncommercial purposes, in microform, paper, electronic and/or any other formats.

The author retains copyright ownership and moral rights in this thesis. Neither the thesis nor substantial extracts from it may be printed or otherwise reproduced without the author's permission.
AVIS:

L'auteur a accordé une licence non exclusive permettant à la Bibliothèque et Archives Canada de reproduire, publier, archiver, sauvegarder, conserver, transmettre au public par télécommunication ou par l'Internet, prêter, distribuer et vendre des thèses partout dans le monde, à des fins commerciales ou autres, sur support microforme, papier, électronique et/ou autres formats.

L'auteur conserve la propriété du droit d'auteur et des droits moraux qui protege cette thèse. $\mathrm{Ni}$ la thèse ni des extraits substantiels de celle-ci ne doivent être imprimés ou autrement reproduits sans son autorisation.
In compliance with the Canadian Privacy Act some supporting forms may have been removed from this thesis.

While these forms may be included in the document page count, their removal does not represent any loss of content from the thesis.
Conformément à la loi canadienne sur la protection de la vie privée, quelques formulaires secondaires ont été enlevés de cette thèse.

Bien que ces formulaires aient inclus dans la pagination, il n'y aura aucun contenu manquant. 


\begin{abstract}
Throughout history, walls and fences have served to secure and defend populations by reconfiguring the political-economic sphere. The objective of this thesis is to identify and examine the various functions of border security walls in the contemporary solidification of capitalist social relations. It seeks to demonstrate how walls, as a part of a spatial strategy of governance, construct conditions for exploitation and the accumulation of wealth. Economic violence and oppressions under capitalism have given rise to expressions of resistance, and it is upon this backdrop that I posit border security walls as techniques of pacification. I employ the case studies of the Apartheid Wall in Israel-Palestine and the US-Mexico border security wall to inform my analysis, giving particular attention to the engagement of border security walls in processes of racialization.
\end{abstract}




\section{Acknowledgements}

First and foremost, I would like to thank my amazing supervisor, Professor George S. Rigakos, for his superb guidance regarding my thesis project, for his insights into navigating academia more broadly, and for providing me with concrete opportunities to advance myself professionally. George, your continuous support and encouragement has been remarkable. Thank you.

I would like to thank Professor Adrian Smith, my second reader, for his excellent feedback. Much thanks to Professor Rebecca Schein for participating in this project as my external examiner. The reflections you both brought to the table were refreshing. Additionally, I would like to thank Professor Justin Paulson, Professor Trevor Purvis, Professor Simon Dalby and Professor Peter Andrée for holding some of the best seminars this campus has ever seen! Thank you to Professor Bill Skidmore for the guidance and support you gave me during my employment here at Carleton. It was a pleasure to TA for you. You are a talented and inspirational educator.

My heartfelt thanks to Donna Coghill, the best administrator in -dare I say it the world. It's clear that you love us. Thank you to the director of the Institute of Political Economy, Professor Janet Siltanen, for your important contributions to the program. You both have helped make the institute the gem that it is. Thank you also to my friends in Political Economy and Legal Studies.

I give my sincere thanks to my family for their love and support. Thank you to my extended family, my brothers and sisters in Students Against Israeli Apartheid, who inspire me every day with their passion and love. Thanks especially to Aidan and Yafa 
for always answering my questions and helping me navigate through some confusing issues.

Thank you also to my friends in CUPE 4600 and at the Leveller. Our experiences together have undoubtedly provided me with a well-balanced education.

Lastly, I would like to thank the hilarious and brilliant Mat Nelson, my friend and academic mentor, who regularly entertained my reflections and queries about theory and process. Your ridiculous book collection has been useful, and your Sir William Petty impressions are rad. 


\section{Table of Contents}

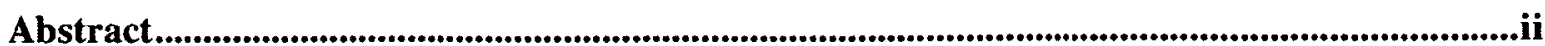

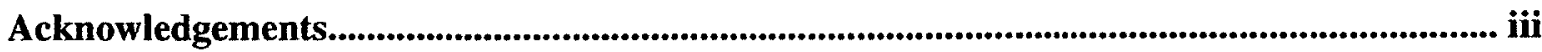

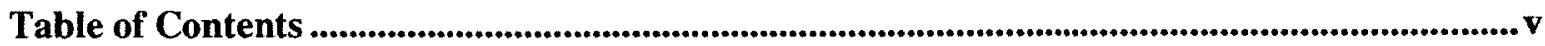

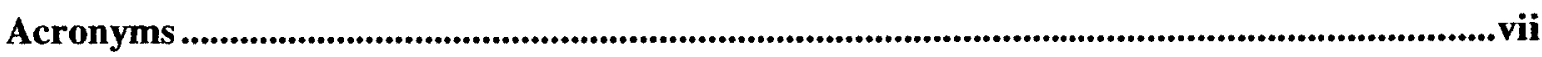

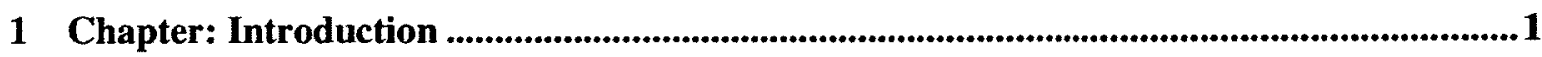

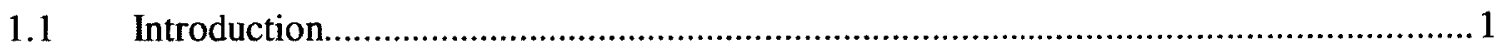

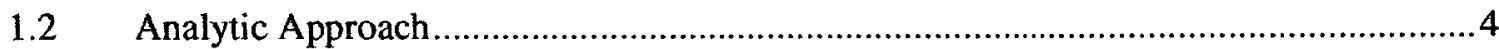

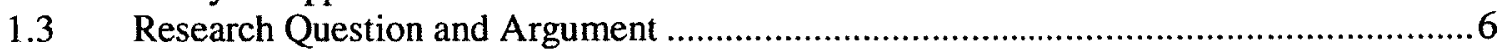

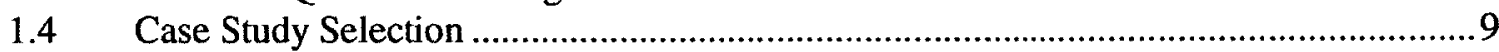

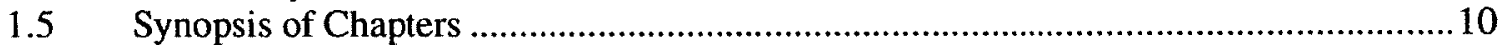

2 Chapter: Theoretical Perspectives and Key Concepts.......................................................12

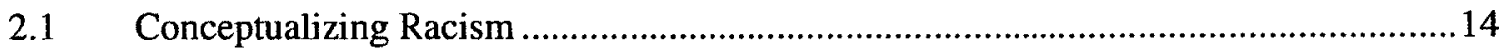

2.2 Contesting Security: hegemony, pacification, and the rule of the pen .......................17

2.3 Space, Race, and Economics: Foucault and Marxist economic geography ..................21

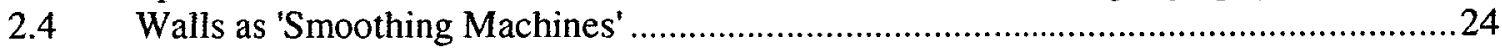

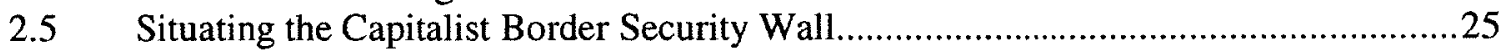

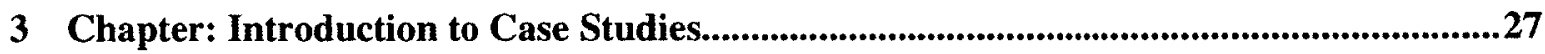

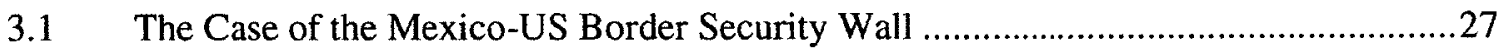

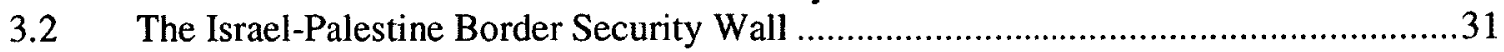

4 Chapter: Facilitating (Neo)colonial Processes .....................................................................34

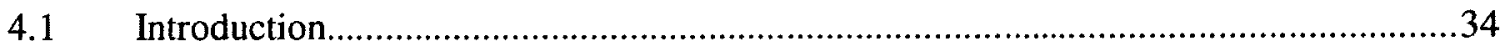

4.2 The Israel-Palestine Border Security Wall as a Tool of Colonialism ..........................35

4.2.1 A history of colonialism in Palestine .............................................................. 35

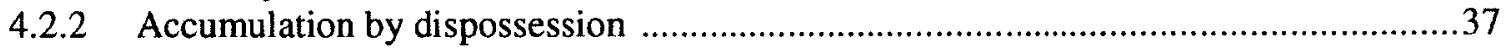

4.3 Mapping the Borderline: American conquest, pacification, and the early militarization

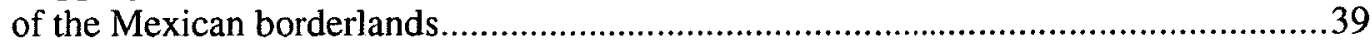

4.3.1 The confiscation of land, the Tejano uprisings, and white superiority ......................42

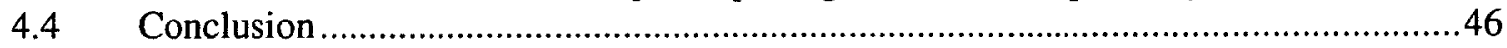

5 Chapter: Constructing Exploitation and Stratifying Labour .......................................48

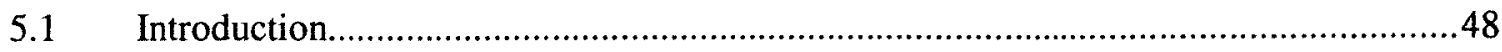

5.2 Historicizing Stratified Labour in Israel: The 'superexploitation' of Palestinian

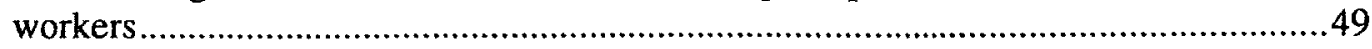

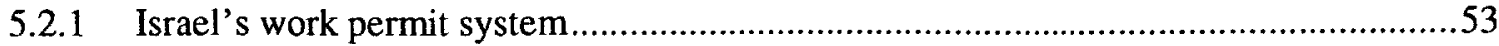

5.2.2 The wall's role in destabilizing the Palestinian economy ........................................55

5.2.3 Race and class stratification under Israeli colonialism .......................................56 
5.3 The Historical Development of Regulated Migrant Labour: Immigration policy as a tool for exploitation in the United States ...................................................................5.

5.3.1 H2 Visas: the institutionalized exploitation of temporary foreign workers.................62

5.3.2 The fences and the discipling of undocumented workers ........................................65

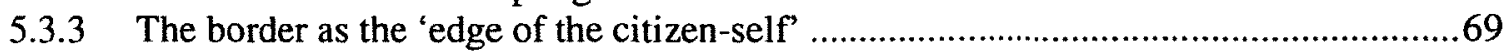

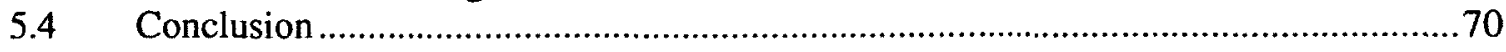

6 Chapter: Facilitating Uneven Development ....................................................................73

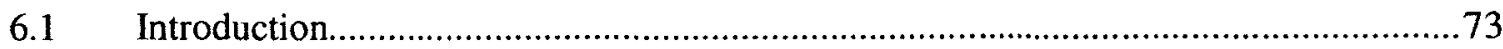

6.2 Uneven Development and the Israel-Palestine Border Security Wall ........................75

6.2.1 Space and the shaping of relations of production in Israel ..........................................75

6.2.2 Uneven development in the era of neoliberalism ...................................................78

6.3 Uneven Development and the US-Mexico Border Security Wall .............................8 80

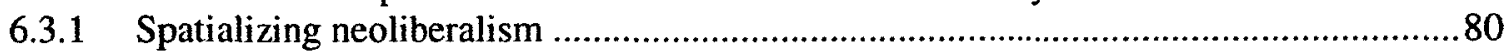

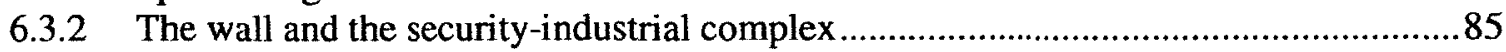

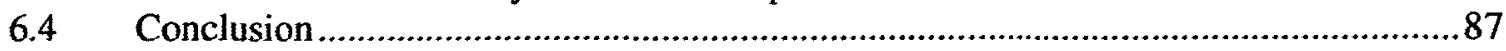

7 Chapter: Repressing Resistance through Ideological and Coercive Mechanisms ............90

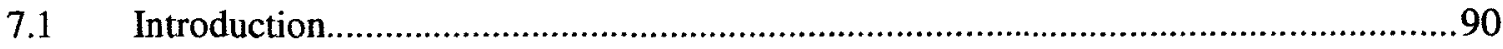

7.2 Coercion, Consent, and the Apartheid Wall ............................................................92

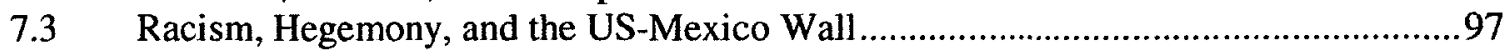

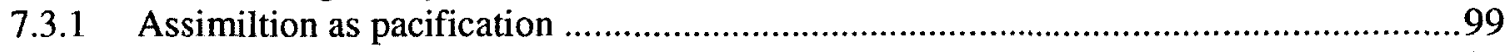

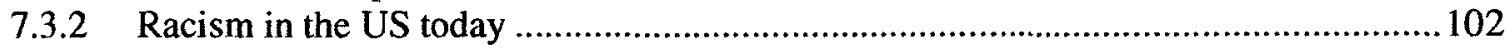

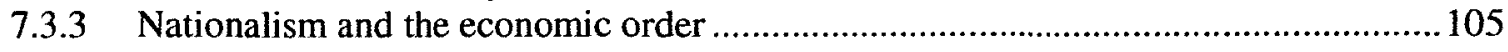

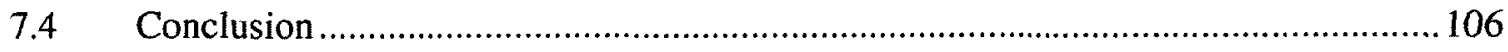

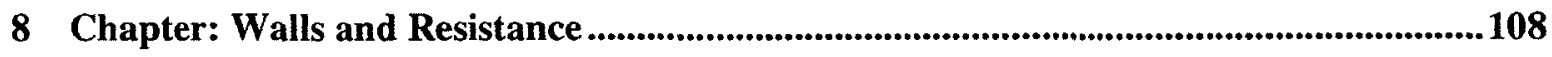

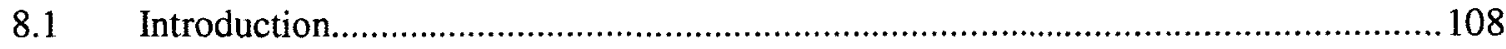

8.2 'To exist is to resist': The Israel'Palestine Wall and the Dialectics of Resistance ..... 108

8.3 Building a Movement of Resistance at the Border and Beyond ..............................111

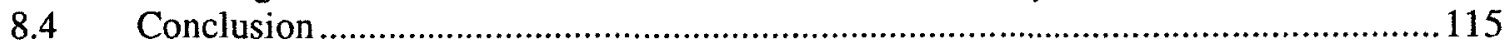

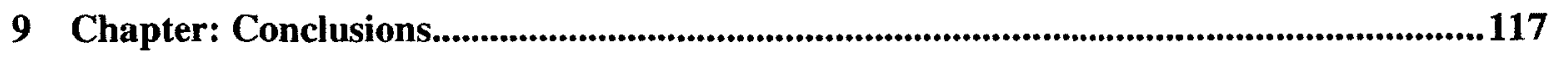

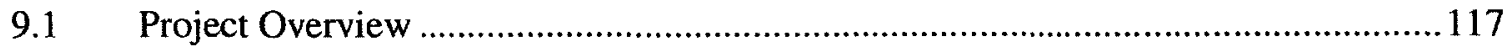

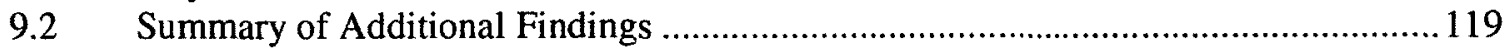

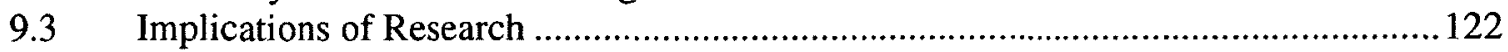

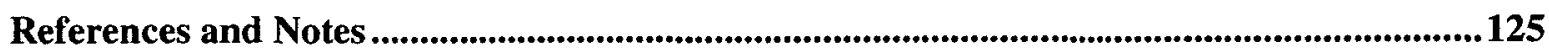

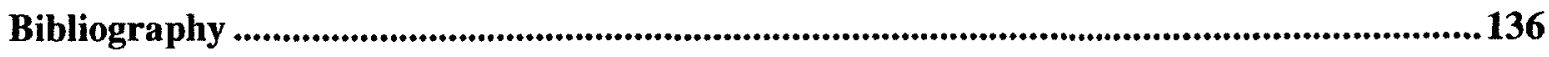




\section{Acronyms}

\begin{tabular}{|l|l|}
\hline CAFOR & Comité de Apoyo Fronterizo Obrero Regional \\
\hline CJM & Coalition for Justice in the Maquiladoras \\
\hline ICE & Immigration and Customs Enforcement \\
\hline IDF & Israel Defense Forces \\
\hline IIRIRA & Illegal Immigration Reform and Immigration Responsibility Act \\
\hline ILO & International Labour Organization \\
\hline INS & Immigration and Naturalization Service \\
\hline IRCA & Immigration and Reform Control Act \\
\hline NAFTA & North American Free Trade Agreement \\
\hline OPTs & Occupied Palestinian Territories \\
\hline PA & Palestinian Authority \\
\hline PASF & Palestinian Authority Security Forces \\
\hline PLO & Palestine Liberation Organization \\
\hline SPLC & Southern Poverty Law Centre \\
\hline
\end{tabular}




\section{Chapter: Introduction}

\subsection{Introduction}

"Essentially starting tomorrow and the days after, the executive board of global capitalism will be meeting here in Toronto behind these fences. They are people responsible for enormous misery and oppression, and they are people who deserve to be confronted. There are people who feel like we should enter into a logic where we want to sit down with them and negotiate the terms of our own misery, or talk about how to make the cages that we're in a little bigger. Well, I'm not interested in that, and groups we're part of and mobilizations we're part of aren't interested in that. We're interested in expressing that anger and that rage and real hope that people have against the capitalist system. This fence is more than a metaphor. I mean there are fences like this all over the world that are responsible essentially for a global apartheid, where on one side you have a global elite, on the other side you have people who are a little bit more privileged who jet town, and then you have others who survive everyday, who have to deal with the police state. And what we see in Toronto is a microcosm of what we see all over the world. And we can fall for this logic of violence versus nonviolence or about lobbying, but I guess I'm here today to stand with people who question the legitimacy of this fence, and support those who want to take down the fence. Take down those fences and those walls that separate us, to take down those fences and walls that prevent us from attacking and I use that word - from attacking the people who are responsible for enormous misery in the world."

- Jaggi Singh, No One is Illegal Montreal, at the fence of the 2010 Toronto G20 Summit.

Jaggi Singh pleaded guilty to counseling to commit mischief over $\$ 5,000$, a charge he received after urging a crowd to take down the security fence.

With inequalities becoming increasingly entrenched in the global economic fabric, social risks have developed, and elites rely now more than ever on new and innovative policing tactics and costly security technologies to surveil the population and protect economic privilege. During the 2010 Toronto G20 Summit, Canadian Prime Minister Stephen Harper spent approximately 1 billion dollars on security for the event, which included the procurement of a multi-million dollar fence to pacify protestors. The cost of 'securing' the Vancouver 2010 Olympic Games, which also featured fencing infrastructure, was also estimated at nearly 1 billion dollars. ${ }^{1}$ These security initiatives are not occurring in isolation. They represent just some of the many government fencing operations occurring across the globe that serve the same purpose: to protect privilege and 'secure' wealth. For those protestors in attendance at the G20 Summit, the fence marked a clear divide between elites and the underprivileged, the terrorist autocrat and 
the dissenter, the oppressors and the oppressed. As Singh stated, this divide is "a microcosm of what we see all over the world." At a local level, fences and walls whether securing elite gatherings or entire gated communities - symbolize crystal clear class divides. And the border/citizenship regime, while certainly not rigid in its class demarcations, draw these lines at the international level.

We are not living in a borderless world. In fact, the separating rows of nation-state borders are perhaps more solidified now than ever, as global elites have successfully garnered massive public resources to develop border security infrastructure. In the last 20 years, fences have been erected along the borders of: India-Bangladesh (2007), IndiaBurma (2003), Saudi Arabia-Yemen (2003), Thailand-Malaysia (2001), Iran-Pakistan (2007), China-North Korea (2003), Spain-Morocco (1993), US-Mexico, BotswanaZimbabwe (2003), Uzbekistan-Kyrgyzstan (1999), Uzbekistan-Afghanistan (2001), and Israel-Palestine (1994), among others. As the West continues to launch imperialist wars and carry out economic apartheid via the global financial regime, mass displacement and poverty drive global migration, and by extension, the global distribution of exploitable labour. The 'Great Wall of Capital,' as termed by Mike Davis, "now brutally separates a few dozen rich countries from the earth's poor majority,"2 emerging as a strategy against the undesired flows of economic and social agents. Yet much resistance is budding across a diversity of spaces.

State actors that profit off of wide-scale oppression have collaborated with the private security and defense industry to develop and expand the state security apparatus, as a method of pacifying resistance to the violence and inequality that has accompanied the expansion of capitalism. This violence sometimes takes overt forms, as seen, for 
example, in the Israeli Defense Force's (IDF) past and present direct military assaults on Palestinians. Sometimes this violence is better concealed, but exists nonetheless in the grave conditions of racialized exploitation facing migrant workers across the world, as experienced, for example, by Mexican foreign workers in the United States. Highly technologized security walls -as an increasingly refined architectural security initiative are emerging enthusiastically across the world to pacify resistance, and perform complex social, political, spatial, and economic functions that safeguard the socio-economic order. This thesis investigates how border security walls and fences, as territorializing agents, regulate space, labour, and mobility to achieve economic goals that effectively consolidate ruling-class power. This entails interrogating the ways in which walls engage with broader state strategies, policies, and practices to deliver symbolic, social and political effects that fundamentally serve an economic ends. Given the racialized quality of the global citizenship regime and the spatial distribution of labour, significant attention must be given to how border security walls appeal to race and racisms to exclude and exploit.

I appeal to two case studies: the US-Mexico border security walls and fences, and the security fences and Apartheid Wall in the Occupied Palestinian Territories (OPTs), as constructed by Israel. I appeal to various theoretical concepts to inform my analysis of each case study. I am interested in these concepts as a toolkit: each offer a distinct utility that together facilitate the construction of cohesive analytical resolutions. This is an analytical thesis project, meaning that I seek to break down my object of analysis into several components. I devise the workings of the capitalist border security wall into elements or social processes. In effect, I perform a disassembling and reassembling. 


\subsection{Analytic Approach}

I approach border security walls through a Marxist lens. This entails framing the border security wall as a component of capitalist economic relations. This placement of the wall becomes necessary when observing the material effects of border security walls -material effects that highlight how the logic of capital accumulation informs the development of border security policy. Marx describes his analytic approach in the Introduction of Grundrisse, in which he emphasizes interrogating the "organic connection" of economic relations "within modern bourgeois society."3 Deconstructing bourgeois economics is a fundamental element of this project. This includes, in part, a dissection of "the categories which go to make up the inner organization of bourgeois society and constitute the foundations of the principal classes: capital, wage-labour, landed property...the organization of bourgeois society in the form of the state...[and] the international organization of production" ${ }^{\prime 4}$ These social and economic forces are reflected in the contemporary border security wall, and must be unearthed.

This entails adopting a historical materialist approach, or a "materialist conception of history," as conceptualized by Karl Marx. Historical materialism asserts that "the mode of production of material life conditions the general process of social, political, and intellectual life." For Marx, material conditions are deeply interwoven with the production of ideas, which in turn, can have a profound affect on the shaping of history. In this thesis project, I perform a historical analysis of each case study, acknowledging the insights historical perspectives - particularly economic histories - can bring to dissecting contemporary phenomena. Important considerations are given to the 
colonial histories of each case, connecting the social and economic legacy of colonialism to the social processes of border security walls today.

Hence, the Marxist paradigm serves as a useful lens to understanding the political economy of border security walls. Given the spatial interrogations of this thesis, critical Marxist geography offers further utility to the project at hand. Various critical geographers have begun to write extensively about the geographical dimensions of capital, and the intersections between the geographical and Marxist traditions. ${ }^{6}$ This is an excellent point of departure to understanding how walls regulate economics in conjunction with the territorialization of space. Marxist theory seeks to explain the specific economic, social, and political structures of society as part of a historicallycontingent process. The form these structures take develops within the history of capitalism itself. ${ }^{7}$ As a result, the Marxist tradition, when fused with geographic concepts of spatial relations, can be particularly useful in understanding the contemporary geographical restructuring of capitalist society. Thus, Marxist geography is useful to the study of how walls affect uneven development and the unequal distribution of wealth and resources through regulating access to space.

Furthermore, a Marxian approach underscores the significance of resistance in systems of power. Accordingly, I conclude my case study investigations with an examination of expressions of resistance found in Mexico, the US, and Palestine. The concept of resistance is crucial to understanding the pacifying effects of walls.

Secondly, critical geopolitics has shaped my analytic approach. Sometimes referred to as "geopolitics from below," critical geopolitics refers to a resistance and contestation of international "geopolitics from above" - the geopolitical discourses of 
hegemonic powers. ${ }^{8}$ It has been inspired by the introduction of contemporary critical social theory and post-structuralist themes into international relations. ${ }^{9}$ According to $\mathrm{O}$ Tuathail, the geopolitics of the past was concerned with imperialist expansion and competing territorial states. However, he argues, this debate must be broadened to incorporate post-colonial, feminist, indigenous, and minority perspectives. ${ }^{10}$ This is what critical geopolitics seeks to accomplish. In this sense, critical geopolitics transgresses disciplinary boundaries. In a socio-political analysis of walls, post-colonial, feminist, and critical social thought can offer important perspectives into the impacts walls have on racialized migrants.

In a critical study of walls, it is necessary to challenge the political rationales dictated by the actors responsible for such security initiatives. Critical geopolitics offers these tools. "Concisely defined, critical geopolitics seeks to reveal the hidden politics of geopolitical knowledge. Rather than defining geopolitics as an unproblematic description of the world political map, it treats geopolitics as a discourse, as a culturally and politically varied way of describing, representing and writing about geography and international politics." " Dominant discourses, such as the post-911 national security discourses, and the anti-immigrant discourses emerging alongside the displacement and transnational flow of peoples, must be dissected and examined in order to understand the ideological roots of security walls.

\subsection{Research Question and Argument}

Border security walls execute various processes. As territorializing agents, walls engage with space to separate, differentiate, divide, exclude, filter, stratify and codify 
populations, while concurrently seeking to homogenize, civilize, and pacify in order to 'smooth' the workings of capitalism and responses to it. This entails the construction of subjectivities that alienate workers from workers in order to further the colonial project of 'divide and conquer.' As a major component of the capitalist security regime, walls and fences play a crucial role in the shaping of racialized identities, and are expressions of a hegemonic discourse that constructs the migrant other as a risk to be controlled. This discourse mirrors colonial thought. With many walls erected along the borders of former colonial/colonized societies, the racist logic of colonialism is still present in the affected society's culture and system of governance, and by extension, its security infrastructure.

This project seeks to explain how border security walls, under capitalism, solidify capitalist economic relations. How is space used to shape the relations of production, and other conditions that consolidate ruling class power?

This project has established four major social processes of border security walls, and I have arrived at these through engaging with a variety of theorists, largely rooted in the Marxist school of thought. The Marxist tradition is concerned with how the expansion of capitalism relies on the development of unequal social relations. Primarily, this entails the construction (and theft) of property, and the abstraction of value from wage labour through exploitation. These two fundamental dimensions of capital accumulation have formed the point of departure on which my analysis is based. This entails an interrogation with history, particularly colonial histories, through which we are able to establish how a regime of accumulation was implemented. This historical materialist approach, with which I incorporate various conceptual tools, including pacification, racialization, and exploitation, has informed the shaping of the succeeding theoretical principles. 
The concepts and theories offered by Marxist economic geographers have been essential to my theoretical development of the border security wall, particularly because this school of thought has identified how the production of space has facilitated the development of unequal social relations. Lastly, the Gramscian tradition has meaningfully informed the establishment of these four points through offering a lens with which to understand how civil society and the state interact, and how culture affects the development of policy and the generation of popular consent to tools of repression and domination.

Through appealing to these schools of thought, I have established that border security walls facilitate four major social processes to solidify capitalist economic relations and, by extension, carry out a project of pacification:

1) The construction of exploitation; the stratification of labour through regulation

2) Facilitating (neo)colonial practices; continuing a history of accumulation by dispossession, and facilitating the institutionalization of private property. Understanding this process entails a dissection of colonial histories in order to situate current neocolonial practices.

3) The spatialization of inequalities through a process of uneven development, as it occurs in an era of neoliberalism.

4) (Re)producing hegemony; engaging in ideological and coercive mechanisms to repress resistance and produce consent to capitalism and security.

Lastly, I will explore walls as sites of resistance, and resistance to the wall, the security apparatus, and the immigration regime.

These four characteristics of border security walls have been formed in conjunction with the guiding principles of the theoretical traditions I am examining within this thesis. Upon analysis of the case studies at hand, it is evident that border 
security walls contribute to the development of unequal social relations to the end of consolidating ruling class power. These four points seek to explain how this occurs.

\subsection{Case Study Selection}

A thoughtful selection of case studies is integral to the development of theory. The case studies selected share many commonalities, but each have informed the project's theory in unique ways. The Apartheid Wall in Palestine and the US-Mexico security fence have been selected as case studies because they share the following common traits:

1) Racism and nationalism are deeply embedded in the social fabric of the wall builders' societies. Each nation is a settler state, and thus each case exemplifies the colonialist dimensions of security. The US, as a hotbed for white supremacy and racialized violence, and Israel, as an apartheid state, serve as important examples to deconstruct.

2) These cases have highly technologized and militarized security infrastructure, speaking to the militaristic dimension of security walls today, and informing an analysis of the relationship between security, militarism and capital accumulation.

3) A strong rhetoric of security is employed by both governments. 'Security' and 'defense' are cited as major justifications for the construction of the walls. Thus, these cases provide for a thought-provoking analysis of security discourse.

4) Each wall was erected for the ostensive purpose of restricting immigration and the movement of people.

5) These fences mark a divide between the West and 'the Rest.' These divisions importantly inform the realities of global inequalities today.

These five features distinguish the Apartheid Wall in Palestine and the US-Mexico border security wall as fitting case studies for this thesis project. They reveal numerous insights into intricate social, political, and economic dynamics of national communities. 


\subsection{Synopsis of Chapters}

The second chapter introduces the major theorists and theoretical concepts I employ to deconstruct the political-economic features of capitalist border security walls. These theories will be explored in greater detail upon presentation of the case study research.

The third chapter looks at how a history of American expansionism shaped the current configurations of the US-Mexico borderline, tracing the securitization of the borderlands to a project of pacification amidst US colonialist endeavours. It argues that the border wall maintains the territorial designations established during this period, and further facilitates neocolonial processes through inscribing neocolonial identities onto the Mexican people. It examines the Israel-Palestine wall as a tool in current colonial practices, and identifies the role of border security walls in continuing histories of accumulation by dispossession.

The fourth chapter argues that the border security wall constructs conditions of exploitation through its various mechanisms of social control, including its surveillance functions. It interacts with other systems, such as the $\mathrm{H} 2$ Visa program in the United States, and discriminatory laws in Israel, to stratify and regulate labour, in congruence with a historical political strategy to incorporate flexible and disposable migrant labour into the US and Israeli labour markets.

The fifth chapter argues that border security walls are part of a spatial strategy to situate workers within the relations of production. Furthermore, the walls are part of broader economic policies to segment labour economics and secure exploitable labour, corresponding to the inherent contradictions within capitalism to equalize and simultaneously differentiate. These contradictions have produced uneven development. 
Border security walls facilitate and restrict the movement of labour as needed, and contribute to a spatialization of inequality within a climate of neoliberalism.

The sixth chapter examines how the wall interplays with racism and other ideological processes to generate consent to the security apparatus. It explores the coercive elements of the border security regime, highlighting its disciplinary functions. It looks at the role the US-Mexico wall plays in assimilative processes, and explores how Zionism in Israel and nationalism in the US are reflected in the walls. It argues that border security walls reproduce hegemonic ideas.

The seventh chapter looks at expressions of resistance in the face of border security walls, militarization, and the citizenship regime. It discusses how actions of repression necessarily entail challenges to power, and it examines the dialectical nature of repression and resistance.

The last chapter provides a brief overview of the arguments presented throughout this thesis, and discusses the research implications of these findings. 


\section{Chapter: Theoretical Perspectives and Key Concepts}

This chapter seeks to outline key theorists and theories that inform an interrogation of the political-economic functions of the capitalist border security wall. As discussed in the previous chapter, my theoretical approach is predominately informed by the Marxist paradigm. I am concerned with the materialist implications of border security walls and their role in the consolidation of class power. This is supplemented with a race-based analysis of the border security regime. This approach places emphasis on structures that produce socio-economic inequality, and seeks to challenge dominant narratives in international relations that reproduce systems of exploitation.

I incoporate anti-racist perspectives to better illustrate the oppressive nature of border security and pacification. I look at the work of Robert Miles and Malcolm Brown to assist me in conceptualizing race, racialization, and racisms. A Gramscian framework guides my examination of the ideological components of border security walls. It is a useful backdrop for contemplating constructions of race, the (re)production of racism, and the sensationalizing of security and threat. In particular, I appeal to the concept of hegemony.

Correspondingly, I explore the concept of pacification as discussed in the works of Mark Neocleous and George S. Rigakos. These authors discuss the ideological and repressive dimensions of the security apparatus, identifying security as hegemony. ${ }^{12}$ It is this theory that forms the theoretical takeoff point for my research question. Through my case studies, I problematize conceptualizations of border security walls as technologies of security and defense. To enhance this argument, I include in this section a discussion of Sir William Petty's London Wall. Scholar Juri Mykkanen hypothesizes that the wall 
exemplifies a distinctive shift in governance that redefines the role of the wall. The theorized London Wall adopts political-economic functions.

This point of departure is further enhanced by the writings of Michel Foucault, specifically his concept of biopolitics, and his political analysis of surveillance technologies. Surveillance is a crucial component of pacification that increases the state's capacity to construct conditions for exploitation.

The theoretical perspectives of Marxist geographers Neil Smith and Doreen Massey have given me the tools to analyze intersections between the economic implications of particular spatial configurations and projects of territorialization to which border security walls belong. I introduce David Harvey's conceptualization of neoliberalism to better situate border security walls economically.

I employ William Bogard's concept of 'smoothing machines' to conceptualize the role of walls in processes of assimilation and the construction of a cohesive social order. Assimilation is an important component of pacification and has undeniable economic effects. This concept offers particular utility in my examination of the US-Mexico border security wall, whereby the wall forms the symbolic and material parameters of the body politic, made cohesive through processes of assimilation.

These theorists all offer distinct contributions to an analytical examination of border security walls. While not all of them share the same methodological approach, each engages with critical theory to interpret society and culture. These theoretical orientations, assembled together, contribute to a broadening of Marxist scholarship. 


\subsection{Conceptualizing Racism}

This project is concerned, in part, with how the border security apparatus is used to exert power over migrant labour, specifically because unregulated migration disrupts just how the global division of labour is structured. 'Regulated labour' refers specifically to workers that are monitored, human flows that are restricted, and working conditions that are manipulated, particularly via legal and policing structures. In sum, it refers to the exercising of authority over labour. Given that the global division of labour is racialized, I interrogate how the operations of the capitalist wall engage with racism and racialization in order to function more effectively. In order to meaningfully address the research question at hand, consideration must be given to how the border security regime exploits racism to achieve its aims.

A racialized geography of labour characterizes today's economic relations. The global labour economy is racialized, reflecting a stratification along racial lines, and also spatialized, meaning that the social relations under capitalism spatially manifest themselves unequally. Although not rigid, the accumulation of wealth under capitalism is geographically concentrated.

This global division of labour is not merely stratified on racial lines: other subjectivities, including gender, ability, and sexual orientation, intersect to shape it. Yet, the accumulation of wealth under capitalism relied on the exploitation of colonized and enslaved peoples, and this was, in part, rationalized through a process of racialization: the social construction of inferiority based on physically visible and/or cultural/ethnic/religious categorizations. 'Race,' as a concept, is informed by these representations, and denotes a dichotomized 'other' -subjectivities defined in accordance 
with perceived difference inferred by those in positions of power (power which is exercised economically, socially, politically, and discursively). A broad definition of 'race,' which acknowledges cultural/religious identities as potential pivots for racist ideas and practice, is necessary, particularly in the context of Israel-Palestine. While 'Palestinian' refers specifically to a national identity, the racialization of Palestinians is partially shaped by popular perceptions of Palestinians sharing Arab/Islamic ethnicreligious roots.

Racism is an ideological mechanism for exercising power over others, achieved through appealing to racial categorizations. It dehumanizes and excludes. It is a tactic of division, and a means of maintaining various forms of privilege, which it accomplishes through engaging with other forms of oppression, notably class oppression, given that today's economic inequalities are profoundly shaped by histories of colonization and racialization. Notably, "The influence of racism and exclusionary practices is always a component of a wider structure of multiple disadvantage and exclusion (including class)." 13 This understanding of racism has been informed by Robert Miles and Malcolm Brown's work, which identifies racism as "primarily an ideology," "manifested in different ways." ${ }^{14}$ This definition of racism emphasizes its distortive nature: racism distorts representations of human beings and the relations between them. ${ }^{15}$ Recognizing the ideological component of racism draws attention to its engagement with hegemonic structures -in so-called Western democracies, the exercising of power relies heavily on the generation of popular consent to state policies and practices. State violence is normalized -or at least passively accepted -through a disfigured presentation of material 
conditions as presented by the state. Racism, then, becomes a form of ideological violence that is (re)produced on a broad scale.

An analysis of border security walls must interrogate the effects of both racism and nationalism precisely because of their role in ideologically rationalizing the construction and reinforcement of physical borders and border infrastructure. Racism and nationalism have, in practice, affected the solidification of capitalist economic relations.

Miles and Brown discuss how racism "became interdependent with the ideology of nationalism."16 They state, "The 'nation' will inevitably identify itself with the 'race,' because historical, cultural, political and other distinguishing factors of a 'nation' are ultimately subsumed under the idea of 'race.' This inevitably leads to a nationalistic purism, an ideology that 'we' must not be contaminated by 'them.",17 This broad conceptualization of race, as provided by Miles and Brown, is particularly useful in understanding racialization in Israel-Palestine, whereby one's national belonging is determined, as outlined in the Nationality Law of $1952,{ }^{18}$ by one's classification as a Jewish person, in accordance with her ethno-religious status. The ideological component of racism is evident here, particularly because this project of exclusion relies on distorted representations of the Palestinian, particularly her devaluation, to justify institutionalized discrimination. However, a definition of racism should take into account not merely discourses, but "all action and processes (whatever their origin or motivation) which result in one group being retained in a subordinate position by another."19 This conceptualization of racism gives emphasis to the consequences of racism, not merely its ideological effects. ${ }^{20}$ Exclusion, which entails the denial of privilege or social advantage, is one of these such practices. 
In the case of US-Mexico, racism also shaped the establishment of the nationstate, and racism forms the bedrock of nationalist discourse in so much as it provides the ideological basis for exclusion. Like racism, nationalism entails the construction of difference and superiority/inferiority, in accordance with the creation of an imagined community and the creation of 'others.' These ideological processes work to deny social privileges via the citizenship regime. Hence, a complete definition of racism must include all individual and institutional practices that result in a sustained or increased subordination of a people. ${ }^{21}$

\subsection{Contesting security: hegemony, pacification, and the rule of the pen}

Sir William Petty, while recognized for his role in shaping English economics during the 1600 s, was integral to the development of a new method of surveillance in England that would profoundly shape governance. Petty envisioned a system of cataloguing -a systematic statistical approach to surveillance -that would better enable sovereigns to control their populations in order to make subjects more productive. His proposed London Wall was a tool to bring this system to fruition.

The wall is perhaps one of the first examples in recorded history whereby the city gates would be guarded "not by sword but by pen."22 Although the wall never actually materialized, it serves as an excellent point of departure for understanding the emergence, under mercantilism, of a shift from walls constructed primarily as tools of self-defense, to walls as part of a larger political-economic project:

Rather than a defensive construction the wall was for Petty a tool to concentrate measurement for administrative purposes. It would have channeled all the different flows that were coming into and out of the city to the gates that were guarded not by sword but by pen. Gates would have been places where the relations intersected, where the proportions were established, where the invisible was rendered visible, and where 
empirical observations were substituted for metaphysical notions. Petty's utopia was to erect a great grid of separation, a calculating machine and organizing tool that did not leave anything outside government. ${ }^{23}$

Petty conceived of its properties and utility. The wall was to be 100 feet in circumference, 11 feet high, and 2 bricks thick. ${ }^{24}$ In vol. 1 no. 11 of the Petty Papers, he states that the wall would serve to "take an accompt of all persons and things going in and out of the Citty," to provide "a foundation of libertyes, securityes, and priviledges" and "to increase the value of enclosed lands." through planned choke-points, where all movement of persons and goods would be made transparent. ${ }^{26}$ Petty understood that walls could be used to codify and manage goods and people, not only to solidify the policing power of government, but to maximize productivity and the generation of wealth. Under mercantilism, governments were concerned with the population as a productive force. ${ }^{27}$

Regulatory economic policies were to accompany the London Wall. Petty proposed the establishment of a council of trade that would regulate plantations, manufacturers, and land and water carriage, and would enforce duty on goods. ${ }^{28}$ As Petty's theorized wall demonstrates, the capitalist wall does not function in isolation, but as a component of a larger regulatory regime. While the wall was to physically direct human and commercial flows, it was situated within a broader administrative structure seeking to solidify the foundations of capitalism. In the $21^{\text {st }}$ century, the state continues to be concerned with the necessary components of economic productivity.

Historically, walls have played a significant role in the defense of territories. Dominant narratives in the field of international relations would suggest that this is still the case. Even critical theorists, such as Wendy Brown, have emphasized how walls are 
part of a reactionary effort to protect dwindling state power. She argues that the phenomenon of nation-state walls are a response to eroding state sovereignty, undermined by the growth of global financial and governance institutions. Accordingly, states are reacting to the effects of neoliberal rationality, which she characterizes as recognizing "no sovereign apart from entrepreneurial decision makers."29 And while maintaining a particular spatial order is an important component to wielding political power, and while walls may play a role in affirming a state's territorial jurisdiction, these explanations do not suffice.

The manufacturing of capitalist economic relations was a violent, coercive process that invited resistance. From the expropriation of land and the forced proletarianization of the peasantry to colonial warfare, violence infused capitalist development. Thus, its architects needed to develop structures to suppress dissent. This gave birth to the security regime under capitalism, which Rigakos characterizes as the securitization of private property and the extension and imposition of property relations and waged labour. ${ }^{30}$

The security apparatus manifests itself in the military, legal, and political institutions of capitalism, which produce a rhetoric of 'security' rooted in liberal thought. This rhetoric highlights the ideological component of securing capitalist relations. By generating hegemony, what Antonio Gramsci refers to as the "spontaneous consent given by the great masses," the dominant social class is able to uphold its control. The function of hegemony is carried out through two 'superstructural levels': 'civil society' and 'the State,' whereby the general population consents to the "general direction imposed on social life by the dominant fundamental group."31 Social hegemony is coupled with "the 
apparatus of state coercive power," which uses various mechanisms of coercion to discipline members of the population into confining to the social order. ${ }^{32}$ Gramsci's concept of hegemony is a useful theoretical tool for this study because it can assist in navigating the complexities of power relations within so-called 'democratic' societies; it is particularly pertinent to examining the politics of racism, as highlighted by Stuart Hall. ${ }^{33}$ In the case of the US, anti-migrant legislation performs coercive functions, but also engages with civil society to (re)produce popular racist attitudes and beliefs that legitimize its coercive elements. In the case of Palestine, the wall -while fundamentally a coercive mechanism -affirms racist constructions of the Palestinian as 'extremist,' while concealing the realities of the Israeli occupation and the root causes of the Palestinian uprisings. This is an application of hegemony.

This rhetoric valorizes threat and effectively masks a central aim of security: pacification. Drawing on the Marx's Communist Manifesto, Neocleous and Rigakos situate the process of pacification as an outcome of social insecurity under capitalism: "The order of capital is an order of social insecurity," which "gives rise to a politics of security." ${ }^{34}$ These politics shape the development of policy, and inform such practices as racial segregation in Palestine and targeted workplace raids in the US. Here we witness what William Rose refers to as a "politicization of danger." 35 According to Neocleous and Rigakos, a 'politics of security' is necessary to legitimize state actions taken to protect capitalist social relations, and pacify its opponents. I apply and expand Neocleous and Rigakos' conception of pacification in my analysis of border security walls.

The development of exploitative structures generate vulnerabilities and dependencies that can have a disciplining effect on subjects. Capitalism is constantly 
attempting to map out relations of domination onto populations, and this is central to the concept of pacification. This process is very much racialized, and should be situated in the colonial histories that profoundly influence global inequalities today. As Miles and Brown establish, "The history of European colonialism is a history of capital accumulation beyond the boundaries of the European nation states...this expansion and settlement has been associated intimately with the process of racialization and the articulation of the ideology of racism." ${ }^{, 36}$ While colonial conquests of the modern era have been characterized as both coercive and ideological 'pacifications, ${ }^{37}$ the contemporary security project continues the disciplining effects of colonialism and facilitates neocolonial practices.

\subsection{Space, race, and economics: Foucault, Massey, and Smith}

Michel Foucault investigates how a particular construction of the body is necessary for the functioning of capitalism. He looks at disciplinary regimes, relations of power, and mechanisms of domination. His theory of biopower, defined as "the set of mechanisms through which the basic biological features of the human species became the object of political strategy, ${ }^{38}$ is relevant to understanding the extent to which walls regulate the individual body and accordingly, the population. Not only do walls physically control bodies through restricting movement, they also, as architectures of surveillance, shape individuals into self-disciplining subjects. Walls facilitate discipline through shaping spaces of governance, rendering subjects visible. As demonstrated in the US-Mexico case study, temporary foreign workers programs permit the circumvention of labour law, enabling exploitable labour, while simultaneously confronting the invisibility of 
undocumented labour. The chokepoints of the border security wall support such a strategy, forcing migratory flows into spaces of surveillance.

The fortification of territorial boundaries creates a space to govern, and by consequence, a space to discipline. Walls furthermore perform this task through spatializing difference and reaffirming social hierarchies. In the case of Palestine, the walls and its checkpoints shape spaces of governance through a strategy of containment: "discipline concentrates, focuses, and encloses." ${ }^{39}$ The construction of space becomes a fundamental component of governmentality.

From the walls of the everyday prison compound to the walled cities of $17^{\text {th }}$ and $18^{\text {th }}$ century Europe, walls can project a notion of criminality onto society's excluded. In the new regime of accumulation, 'criminality' was connected to the idea of 'rebellion,' 'disobedience,' and 'disorder. ${ }^{, 40}$ 'Criminality' was that which threatened the social order, particularly in light of the new 'delinquent' behaviours that accompanied urbanization: gambling, drinking, adultery, and 'wandering. ${ }^{41}$ While these actions today can directly threaten the commercial interests within a neighbourhood, the construction of delinquency and the criminalization of the 'idle poor' is further necessary to: mask the root causes of social instability under capitalism; develop fear and hostility among workers; and propagate a liberal logic of security that generates legitimacy for policing and military institutions whose central goal is the suppression of dissent.

Foucault establishes that in the $18^{\text {th }}$ century, the police and judicial bodies were necessitated through a propagated fear of the criminal. A punitive apparatus was established as part of a wider strategy to separate the normal and the abnormal, as well as the productive and unproductive. ${ }^{42}$ The penal system allowed for differential applications 
of the law, enabling a particular construction of power: "the differential administration of illegalities through the mediation of penalty forms part of those mechanisms of domination. ${ }^{43}$ The penal system was concerned with the coordination of bodies through strategic social inscriptions. While prison walls separate 'delinquents' from the rest of society, border security walls also codify and coordinate accordingly. As Foucault highlights, racial codifications are incorporated into the modern state's exercise of biopower. ${ }^{44}$ In this vein, the theory of biopolitics contributes to an analysis of how walls function in Israel-Palestine and the US-Mexico as part of a strategy of governing racialized populations. Just as delinquents were excluded from society to sustain structures of power, racialized peoples have faced similar treatment.

While Foucault focuses on the role of space in governmentality, Marxist geographers Doreen Massey and Neil Smith emphasize the significance of spatial strategy in capital accumulation. In Spatial Divisions of Labour: Social structures and the geography of production, Massey argues that "spatial change is not just an outcome of economic restructuring and social recomposition: it is integral to both." ${ }^{45}$ While border walls and fences have been largely associated with geopolitical strategy, their economic and social functions have not been thoroughly dissected. As a broadly employed tool of governmentality, walls serve as an important object of analysis for interrogating the significance of physical architecture in the capitalist political-economic project. I appeal to Smith's theory of uneven development. In sum, uneven development is "the concrete manifestation of the production of space under capitalism." ${ }^{\text {"46 }}$ It "refers not simply to the geography of capitalism but also to uneven rates of growth between different sectors of the capitalist economy." ${ }^{, 47}$ Furthermore, it is "the essence of contradiction." It is the 
geography of the inherent contradictions of capitalism, particularly its contradictory tendencies towards both equalization and differentiation, which determine the production of space. ${ }^{48}$ I use Smith's theory of uneven development to explore how walls, as a features of the built environment, affect the spatial manifestations of inequality, particularly in regards to the utilization of space in the construction of a territorial division of labour. In the case of Mexico, spatial separation plays an important role in maintaining low wages within Mexican industry. In Palestine, the wall has obstructed economic flows and has impeded many Palestinians' ability to access goods and services. The destabilization of the economy has likewise suppressed wages. I consider how neoliberalism influences uneven development.

\subsection{Walls as 'Smoothing Machines'}

In "Smoothing Machines and the Constitution of Society," William Bogard asks his readers to "imagine society as a production of smoothing machines. ${ }^{, 49}$ He uses the term 'smoothing machines' to refer to often contradictory processes of objectification and subjectification that 'smooth' society, sometimes facilitating social control. Citing Deleuze and Guattari, these 'smoothing machines' can be "technological, musical, maritime, mathematical, physical, and aesthetic," to which Bogard adds the category of 'social.' While walls can be conceived as aesthetic, physical (spatial-material), technological, and mathematical, framing the wall as a 'social' machine is most useful to understanding its engagement with other social processes, particularly racism and pacification. For Bogard, the social smoothing machine "generates blockages, exclusions, and dissipates energies. It also creates zones of inclusion, vitality, and freedom." ${ }^{50}$ While 
the wall itself may not be understood as a smoothing machine that creates zones of freedom, its antithesis - various manifestations of resistance -fulfill this role, revealing the impermanency of walls.

Walls, as smoothing machines, seek to create homogenous populations that are predictable, stable, coherent, and obedient. As capitalism requires "the constant revolutionizing of production," and the "uninterrupted disturbance of all social conditions," 51 walls help to filter out 'threats' to the social order, while seeking to amalgamate the governed population under one hegemonic bond: "It [the bourgeois order] has agglomerated population...lumped together into one nation, with one government, one code of laws, one national class-interest, one frontier and one customstariff." 52 Walls can be seen as producing a "plane of consistency" whereby "the most heterogeneous matters are made to resonate together in a homogenous mixture." 53 Thus, I use the concept of 'smoothing machines' to contemplate the role of the wall in processes of assimilation in the United States, conceptualizing assimilation as an important dimension of pacification, and an important element in constructing conditions for exploitation.

Those that perceivably pose a threat to the national interest or national identity are differentiated from the masses and excluded. So while walls homogenize and consolidate, they paradoxically separate and produce difference.

\subsection{Situating the capitalist border security wall}

I frame the social processes of the capitalist border security wall, firstly, within the sphere of neocolonialism because resource exchanges reflective of the colonial model are taking 
place, and the legacy of colonialism is present in the unequal social relations of the global economic system. Neocolonialism does not encompass the existence of formal colonies or direct political rule by the economic power. In the case of Palestine, however, Israel has formal political rule over indigenous Palestinians, and physically occupies Palestinian land. Thus, the border security wall also operates within the context of 'capitalist colonization, ${ }^{54}$ or 'settler capitalism.'

Miles and Brown note that in the aftermath of World War II, and succeeding a wave of strategic national liberation movements, European colonialism was replaced by two developments: the establishment and growth of the transnational corporation, and the development of 'supra-nation-state institutions. ${ }^{.55}$ It is the former which will primarily inform my deconstruction of the capitalist border security wall. David Harvey conceptualizes neoliberalism "as a political project to re-establish the conditions for capital accumulation, and to restore the power of economic elites." ${ }^{, 56}$ It entails the redistribution, rather than the generation of wealth. ${ }^{57}$ This occurs through the expansion of the private sector, the slashing of social services, and the growth of transnational corporations and finance capital. Neoliberalism profoundly shaped the nature of economic relations today. 


\section{Chapter: Introduction to Case Studies}

\subsection{The Case of the Mexico-US Border Security Wall}

The US-Mexico borderland is a peculiar space. In one vein, it is a vibrant place of cultural exchange where two worlds mingle and interact both fluidly and abruptly. But amidst the flows and the blockages of these colliding spaces there is a terrain of violence. Might is flashed and rights are suspended in zones the authorities declare as non-place. Transitory bodies seek to reconquer the dessert plains, escaping the sight of possible repressors. At the borderlands, neo-fascist vigilantes aim to protect 'their' so-called homeland traditionally belonging to the people they violently target. At the border, divides are drawn, and a socially-constructed line with asymmetrical sides is reinforced by militaristic manifestations of power and wealth. Force becomes normalized, and surveillance increasingly characterizes the parameters of the nation-state.

In 1990, the United States Border Patrol began erecting a 10-foot high fence, composed of welded steel, covering 14 miles of the San Diego border. ${ }^{58}$ In the succeeding years, "the boundary-enforcement apparatus exploded with the emergence of geographically focused 'operations." ${ }^{, 59}$ Barricades were erected in Southern Arizona, Brownsville, and El Paso, marking a clear divide between Mexicans and their American counterparts.

The Secure Border Initiative was announced on November 2, 2005, aiming to increase 'physical layers of security,' encompassing walls, fences, and barricades. ${ }^{60}$ In 2006, the Secure Fence Act was signed into law, sanctioning the construction of 850 miles of at least two layers of reinforced fencing surrounding patrol roads. Multibillion dollar 'virtual fence' technologies have been deployed, outsourced to companies such as 
Boeing and its subcontractors. 98-foot towers were constructed in Southern Arizona, topped with cameras, sensors, radar and other surveillance equipment. ${ }^{61}$ These are accompanied by biometric screening technologies at points of entry along the border, which recognize and register vocal, retinal and facial features. Inter-operational databases collect, track, and coordinate information on individual movement. ${ }^{62}$

It is important to interrogate why extensive public resources are being funneled towards the development of security fencing along the US-Mexico border. While the industrial-security complex has poured billions of dollars into the pockets of private security firms, the fences are also a response to a political climate shaped by big business lobbyists and xenophobic right-wing hysteria that has its roots in a carefully crafted narration of the white nation and 'Americanism.'

Historically, the US-Mexico borderland has been a site of contested space. American conquest, infused with racism, led to the dispossession of land from many Mexican families. Nearly half of what was Mexico was conquered by American militias. Rebellion was the inevitable response to this colonial conquest, and thus the borderlands have a deep history of violent pacification; this has been accompanied by an increasing militarization of space. A conquest fuelled by the racist rhetoric of Manifest Destiny, the border was established by military force during the US-Mexican War of 1846-1848. The principle of Manifest Destiny affirmed that it was the inherent right of the American (Anglo) people to expand its culture and territory, and by extension, its economic system. While Manifest Destiny developed specifically in America, ideologically it can be grounded in the logic of the colonizing mission, as employed elsewhere across the globe. Indeed, it was used to ideologically support the American colonial project, which entailed 
the appropriation of resources to fulfill the colonist's economic interests. "Using claims of Mexican backwardness and the promises of American Progress, expansionists sought to impose a moral economy of production in the region dominated by free-hold yeoman farmers." ${ }^{63}$ The sense of moral superiority characterizing Manifest Destiny was framed around the fashioned moral and cultural inferiority of the Mexican.

The wall enables greater regulation of subordinate social groups. This is a fundamental function of surveillance. The wall's chokepoints filter codified bodies into the body politic, and those unwilling to be assimilated are often targets of repression. This repression is legitimized through racist constructions that devalue outsiders particularly migrants. Criminalities associated with immigration are fashioned through various legal mechanisms, which then facilitate the exercise of force against targeted groups. The material consequences for migrants can be devastating, and thus this process of criminalization serves as an effective intimidation tactic.

The outpouring of resources into the security fences and the border regime are legitimized through the construction of threat. Foucault writes that "thanks to the studiously cultivated fear of criminals," the masses "tolerate the maintenance, or rather the reinforcement, of the judicial and police apparatuses." ${ }^{.64}$ While these apparatuses are crucial to maintaining a social order that tolerates capitalist economic relations, they are also important in generating compliance to exploitation.

In the US, migration has been facilitated when employers have been successful in their demands for cheap and exploitable labour. Limited economic opportunities at home have increased pressures to migrate, with the possibility of sending remittances back to family members. In the US, a historical trend in favour of flexible migrant labour has 
been witnessed, whereby migrant workers can be deported when necessary, in accordance with a variety of social and economic factors, such as fluctuations in the economy. Documented labour has, at times, been favoured politically because it flexibilizes labour. Furthermore, it increases the capacity of the state to monitor dissidence, given that marginalized social groups could pose a threat to the social order. Temporary foreign worker programs have been used as instruments to deny workers the right to collectively bargain. They outline other exploitative terms of employment that domestic workers are protected against.

Compliance with exploitation is maintained through securing particular social conditions. A racist climate, which backs the security apparatus and inequitable immigration policy, is one such condition. Yet, as noted by Kitty Calavita, "the location of immigrants in the political economy is fraught with contradictions," politicians and the public have resisted temporary foreign worker programs despite the political clout of agribusiness and industry. This reality speaks to the influence of resistance movements that have decried temporary foreign worker programs as exploitative, but it also speaks to the rampant racism that deplores most forms of immigration. Paradoxically, this racism enables extensive exploitation to exist when temporary foreign worker programs are successfully implemented.

An exploration of the exploitative aspects of border security walls should interrogate how the rights of workers, once integrated into the labour economy, are restrained. Through documenting the development of temporary foreign worker programs in the United States, the state's preference for regulated, disposable, and exploitable migrant labour becomes evident, despite anti-immigrant sentiment that calls for restricted 
migration. I examine how racism -as a hegemonic structure- affects the development of border security policies. This entails contemplating the historic role of racism in the appropriation of land, the construction of borderlines, and the militarization of the border region. The wall is a continuation of this American colonial project, and thus facilitates neocolonial relations today. Erected alongside the implementation of neoliberal economic reforms, it is a tool in spatializing relations of exploitation and consolidating class power historically rooted in colonialism's reallocation of resources. Finally, I look at how the wall, as a tool of social control, acts as a 'smoothing machine,' seeking to assimilate outsiders while paradoxically accentuating difference. Yet power is not unidirectional, and smoothing machines are not perfectly operational. The wall, as an expression of power relations, provokes profound resistance towards a regime of violence, with migrants rejecting the criminal and obedient subjectivities bestowed on them, reclaiming their rights through confronting political and economic power.

\subsection{The Israel-Palestine Border Security Wall}

The separation wall in Palestine is a technology of pacification veiled as a security measure to protect Israelis from Palestinian militants. Expanding for 723 kilometres $^{66}$ from north to south, the wall along the West Bank features layers of razor wire, electric fencing, surveillance cameras, watch towers, trenches, sensors, ditches, and patrol roads. The concrete wall is 8 metres tall, which is twice the height of the Berlin Wall. ${ }^{67}$ While the wall's various architectural components are essential to its role in codifying, filtering, separating, excluding and controlling Palestinians, the wall is only effective to the extent 
that it strengthens the application of other regulatory and repressive mechanisms employed by Israel.

Palestinians witnessed increasing controls on their movement in the period following the 1993 Oslo Accords, which crystalized the pass and closure system and led to the fragmentation of the Palestinian territories, particularly the segmentation of the West Bank into Areas A, B, and $\mathrm{C}^{68}$ Barriers to movement have included: internal border closures and checkpoints, roadblocks, security fences, and the apartheid wall. From April 2009 to March 2010, the United Nations Office for the Coordination of Humanitarian Affairs, occupied Palestinian territory, documented 505 total "closure obstacles." ${ }^{.69}$ As a result of these barriers between Palestine's urban hubs -including Nablus, Jenin, Ramallah, Hebron, Jericho, and East Jerusalem -vendors and farmers have faced reduced access to their markets. ${ }^{70}$ While this figure marks a 19 percent decrease in closure obstacles from the previous year, the report notes that "no significant improvement took place in the access of Palestinians to areas behind the barrier."

The wall, as a part of Israel's border security regime, ensures that relations of exploitation and domination can continue to be mapped onto the desired people and spaces. The wall seeks to control the social and economic spheres of Palestine, and it does so in conformity with non-material forms of regulation, including Israel's work and travel permit system and its discriminatory employment laws. The wall -which carries out various economic, political, psychological, and material functions -demonstrates the significance of spatial control in the advancement of Israel's capitalist colonial project. As a component of Israel's closure system, the wall has devastated the Palestinian economy to the benefit of the Israeli ruling class, deepening capitalism's geographical 
pattern of uneven development. It has appropriated land and other resources as a part of the capitalist colonialist process of 'accumulation by dispossession,' and as a mechanism of reterritorialization. But the wall's reproduction of specific economic, social, and political structures must be viewed as part of a historically contingent process. The social processes of the wall should be contextualized by Israel's colonialist past and present. The wall has furthered an unequal distribution of wealth and resources through regulating access to space. However, Palestinian workers were positioned in the labour economy as 'superexploitable' well before the erection of the wall. Interrogating this history is necessary to conceptualizing how the wall today furthers relations of exploitation, and engages in a project of uneven development.

Following the Second Intifada, Israel had obtained enough political capital to carry out the erection of the West Bank wall. It has been legitimized through various ideological tools, including Zionism, Islamaphobia, and right-wing discursive affirmations on 'national security.' The wall engages with these hegemonic ideas in service of Israel's capitalist colonialism. But the wall has also inspired resistance. This resistance is central to reframing debates surrounding the wall, bringing attention to its illegality and violence. 


\section{Chapter: Facilitating (Neo)colonial Processes}

\subsection{Introduction}

Following the establishment of the state of Israel in 1948, the British occupation of Palestine formally ended, and Indigenous Palestinians were subject to Israeli rule amidst the aftermath of the 1948 Arab-Israeli War. In 1949, the Green Line was established, which demarked Gaza and the West Bank as Palestinian territories. The first section begins with a brief history of colonialism and war in Palestine, beginning with the issuing of the Balfour Declaration in 1917. I then discuss how the wall operates today in light of this history, demonstrating how the wall is used as a tool to further the colonization of Palestinian land. I discuss how the production of space is essential to the execution of colonial practices, and I examine how the wall acts as a territorializing agent. I present David Harvey's definition of accumulation by dispossession, and I explore how the wall engages in this process, giving particular emphasis to the dispossession of land and resources, and the manipulation of property values. I identify accumulation by dispossession as a central feature of colonialism.

The second section outlines how US colonialism violently constructed the USMexico borderline. It explores how, under colonialism, and through strategies of accumulation by dispossession, a regime of private property was enforced in traditionally Mexican land. I demonstrate just how pacification was used in the territorialization of the US-Mexico border, and I discuss how a project of pacification characterizes the US colonial project. I begin with an examination of the US Mexico War of 1846. I look at the Cortina War (1859-1860), and other US expressions of repression against Tejanos, ${ }^{72}$ up until 1915. I examine how racism characterized these histories, and I explore how US 
whiteness is consolidated in the narration of American expansionism. Identifying histories of racism towards Latina/os contextualizes the culture of racism present in the US today. This chapter seeks to connect the current militarization of the US borderlands to a history of colonialism in order to position the border wall as a neocolonial practice. Appealing to each case study, I demonstrate how one of the major characteristics of walls is to facilitate (neo)colonial processes.

\subsection{The Israel-Palestine Border Security Wall as a Tool of Colonialism}

\subsubsection{A history of colonialism in Palestine}

In 1917, Britain issued the Balfour Declaration, which stated its support for the creation of a Jewish homeland within Palestine. In 1923, the British Mandate for Palestine was a legal mandate established by the League of Nations that expressed support of the Balfour Declaration, and officially ceded Palestine to Britain amidst the dissolution of the Ottoman Empire. For several decades, the Zionist movement in Palestine would fight for political autonomy from the British, eventually culminating in a declaration of independence in 1948 by Zionist leaders, and the establishment of the State of Israel. Statehood was formally recognized by the United Nations in the UN Partition Plan for Palestine, which deemed 56.47 per cent of the British Mandate for Palestine as belonging to the newly formed Jewish state. Following the 1948 Arab-Israeli War, Israel had conquered approximately 77 percent of Palestine. The Green Line was established in 1949 as a border excluding Gaza and the West Bank from Israel, which were occupied by

Egypt and the Hashemite Kingdom of Jordan, respectively. ${ }^{73}$ Between 600,000 and 1 million Indigenous Palestinians were displaced and became refugees, relocating in 
Lebanon, Syria, Gaza, the West Bank, and elsewhere. ${ }^{74}$ Through international support and military strength, Israel had established itself as a colonial settler state in historic Palestine, and would become a booming and prosperous player in the global capitalist economy. Today it is the world's fourth largest nuclear power, and its fifth largest arms exporter. ${ }^{75}$

Israel's occupation of Gaza, the West Bank, and East Jerusalem began in 1967 following its victory in the Six-Day War. Those under Israeli military occupation in the West Bank and Gaza would not become Israeli citizens, unlike Palestinians that remained in Israel proper following the war in 1948. Through its military strength, Israel would continue to confiscate land from Palestinians. Israel's colonial conquest of the West Bank and Gaza "introduced a large pool of cheap labour and free (confiscated) land into the expanding Israeli economy." ${ }^{, 76}$ More than 30 percent of land in the West Bank was transferred to Israeli settlers or the military. ${ }^{77}$ Israel's economic policies affecting the occupied Palestinian territories (OPTs) resulted in the mass confiscation of land and the proletarianization of Palestinians. Israel's policies actively undermined the Palestinian economy, and this created new forms of cheap and exploitable labour for Israel's businesses. Following the war, Palestinians faced extremely high levels of unemployment in the OPTs. Meanwhile, Israel was facing labour shortages in its construction, agricultural, and service sectors. The molding of Palestinians into cheap, disposable and flexible labour for the Israeli economy "was assisted by the undermining of Palestinian economic capacities caused by Israel's occupation policies, especially massive land confiscations, control of water resources and administrative restrictions on production 
and marketing of agricultural and industrial commodities that might compete with Israeli products."78

In 2005, under Israel's 'disengagement plan,' Israel had formally withdrawn from Gaza and select settlements in the West Bank. However, it continues to dominate the territories through its policies of enclosure and separation fortified by the wall, and Israeli settlements continue to occupy the land, protected by the wall. Over 400,000 Jewish settlers live in 137 settlements in East Jerusalem and the West Bank, and more than 100 outposts have been established as grounds for future settlements. ${ }^{79}$ The Oslo Accords and succeeding agreements, including the Taba Agreement and the Wye River Agreement, have not settled three main issues of dispute: Israel's settlements in the OPTs, the rights of return for Palestinian refugees, and the annexation of East Jerusalem. ${ }^{80}$ These issues are all central to Israel's colonial project, and reflect Israeli policy that targets the space Palestinians inhabit. Sari Hanafi uses the term 'spacio-cide' to refer to this colonial process, because "in the Palestinian-Israeli conflict, the Israeli target is the place." result, the right of return has become central to the Palestinian resistance movement. It "becomes the very point at which the entire colonial aspect of Zionism is undermined." 82

\subsubsection{Accumulation by Dispossession}

David Harvey uses the term 'accumulation by dispossession' to refer to "the continuation and proliferation of accumulation practices which Marx has treated of as 'primitive' or 'original' during the rise capitalism., ${ }^{, 83}$ For Harvey, accumulation by dispossession consists of "the commodification and privatization of land and the forceful expulsion of peasant populations...commodification of labour power and the suppression of alternative (Indigenous) forms of production and consumption; [and] colonial, 
neocolonial, and imperial processes of appropriation of assets (including natural resources)..."84 Just as the enclosure movement used fences -architectures of demarcation -to privatize land and expulse peasants from the land, so too does the Apartheid Wall displace Palestinians. This colonial practice is part of a broader strategy of accumulation by dispossession.

The occupation, demarcation, and regulation of space are crucial to the execution of colonialism. The wall has been a fundamental tool in the colonization of land.

Significantly deviating from the Green Line, as established in the 1949 Armistice Agreements, the wall has a significant role to play in the reterritorialization of Palestinian land. The wall appropriates approximately 11 percent of the land area of the West Bank. ${ }^{85}$ It has, to a degree, 'secured' Israeli settlements in the OPTs by routing deep inside the West Bank by more than 16 kilometres, ${ }^{86}$ further isolating Palestinians and marking a clear delineation between 'us' and 'them': the colonized and colonizers.

The wall has played a role in the shaping of property values. This is exemplified in the case of Abu-Dis, a Palestinian town on the edge of Jerusalem. The barrier has not only completely blocked access to Jerusalem, it has also blocked many of the town's residents from accessing Al-Quds University, which sits at the town's edge. At one point, the local student housing market led to an overall increase in the town's property values, however since the construction of the wall, land has depreciated by 60 percent. ${ }^{87}$ Many Palestinians have emigrated from the town, and university enrollment has decreased. Through restricting access to the educational institution, Israel is also restricting Palestinians' capacity to obtain good jobs, highlighting the magnitude of the wall's pervasiveness in the economic sphere. 
While in many instances the wall has depreciated property values in the OPTs, it has also conversely increased them in predominately Jewish regions and in areas planned for settlement expansion; this is often to the benefit of real estate investors. Eyal Weizman, citing a report published by the human rights organization B'Tselem, discusses how the carefully-crafted routing of the wall has redistributed wealth to real estate firms at the expense of Palestinians and the Palestinian economy. Through reconfiguring the built environment, the wall is furthering 'capitalist colonialism':

According to a report published by human rights organization B'Tselem, in some cases, "reasons for routing reflected the interests of real estate companies with existing construction contracts on the land on which they had already made a large investment. The annexation of colonized lands had the potential to yield enormous profits. That there was much money to be made -or lost -by the routing of the wall intensified the conflict over its path. Indeed, following the principles of Israel's capitalist colonization, prices of properties left to the east of the wall immediately lost 10-15 percent of their value...In settlements left to the west of the wall, as the Israeli historian and activist Gadi Algazi noted, 'real estate developers could promise middle class Israelis the luxury and security of gated communities, with the local Palestinian inhabitants barricaded out of site. ${ }^{, 88}$

The wall's routing corresponds to Harvey's theory of accumulation by dispossession through its active displacement of resources and commodification of land. This process of "capitalist colonization" is a driving force behind the construction of the wall. History has a crucial role to play in the shaping of social and economic relations and their manifestation in spatial configurations. This is particularly evident in colonial and postcolonial societies.

\subsection{Mapping the borderline: American conquest, pacification, and the early militarization of the Mexican borderlands}

While the security wall delineates the territorial bounds of the United States - attributing physical space to the nation's imagined community - establishing these territorial foundations was very much a violent process of American conquest. As a settler state, the 
United States rests itself upon colonized indigenous land. The process of colonization continued through the appropriation of land from Mexicans. The continued exclusion of Mexicans from much of the American southwest thus marks a prolongation of racial and territorial domination. The construction of Mexican migrants as 'outsiders' is then based on a profound ignorance of the Mexicana's historic roots.

An analysis of the US conquest of Mexican land highlights how the borderline has historically been a point of dispute and a site of conflict. Understanding this history helps us to better trace the beginnings of border militarization and the functions it serves. The current parameters of the US state have been declared through force. So while the American pacification project takes unique spatial manifestations across the country, the US-Mexico border is a space where security infrastructure is concentrated and surveillance is heightened. But the border's architectures of security should not narrowly be understood as part of a concerted effort to preserve US sovereignty - a viewpoint that emphasizes the protection of a united political community and its judicial territory. While US expansionism can partially be attributed to the state territorial project, the dispossession of Mexicans from their land along the border more accurately served the purpose of increasing wealth for American elites -a goal that has been actively pursued by the state apparatus. The dispossession of land is a defining characteristic of colonialism, marking the structuring of the border as a (neo)colonial practice.

The US-Mexican War of 1846 was a defining event in the history of the USMexico borderlands and the territorialization of the US state. Largely portrayed as a splendorous victory in the mission to build the American nation and expand American values, the violent realities surrounding such a ruthless military assault on Mexicans are, 
for the most part, concealed within the narrative of the nation. Where violence is acknowledged, it is glorified. Michael J. Shapiro explores how such a narration has been fundamental to the constitution of that which is 'American,' and this has affected immigration policies - shaped by "cultural anxieties about appropriate personhood." Accordingly, "The retelling of the myth of violent (yet sacred) expansion has been a dominant mode through which 'America' has performed its legendary national identity." He continues, "such textual performances... are especially pertinent to the politics of constructing the alien other." ${ }^{\prime 89}$

Few have attributed the war of 1846 to the American colonizing project. As Gomez highlights, mainstream American history has taught that the frontier -as an empty, unpopulated space -was "settled by brave and hearty pioneers." ${ }^{.90}$ But the frontier was neither empty nor uncontested. It was configured through conquest: a project of intimidation, violence, racism, and dispossession. Limerick describes conquest as: "the drawing of lines on a map, the definition and allocation of ownership... and the evolution of land from matter to property." Establishing the frontier entails the "initial drawing of the lines," then "the giving of meaning and power to those lines, which is still under way." $" 91$

Creating and maintaining the social construction of the borderline has required the racialization of Mexicans, and the military/policing institutions established to enforce the borderlines serve to reproduce their racial subordination. While the wall seeks to authorize the territorial boundaries established illegitimately through force in the 1800 s, it also pursues a racialized construction of the Chicana/o that developed during this period of American expansionism into Mexican territory. Through further tracing this history of 
conquest, we are able to frame the US-Mexico security wall as a continuation of the American colonizing mission. As Neil Smith notes, "the relativity of space becomes not a philosophical issue but a product of social and historical practice." 92

\subsubsection{The confiscation of land, the Tejano uprisings, and white superiority}

In 1846, US soldiers invaded Mexico and occupied the land. The US-Mexican War culminated in the Treaty of Guadalupe Hidalgo, which was followed by the Gadsden Purchase of 1853. Mexico, which had obtained its independence from Spain in 1821, surrendered approximately half of its territory: the land which is now Texas, Arizona, New Mexico, Utah, Nevada, California, and Colorado.$^{93}$ The Treaty of Guadalupe Hidalgo formalized this take-over, setting the Rio Grande as the boundary between the two nations. The treaty would affect approximately 100,000 Mexicans, ${ }^{94}$ including Native peoples, Mestiza/os, and Raza, ${ }^{95}$ converting many of them into American citizens. Those that retreated to Mexican territory, as acts of resistance, ${ }^{96}$ or declared their Mexican citizenship before a judicial official, were excluded from this conversion. The treaty also granted Mexicans the right to maintain possession of their land. ${ }^{97}$

However, in practice, the rights to land enshrined in the treaty were not respected. In Texas, many Tejanos were unable to reclaim land that was dispossessed by Anglos after the Texas Revolution (1835-1836) ${ }^{98}$ Under the advisement of US President James K. Polk, the US Senate struck Article 10 of the Treaty of Guadalupe Hidalgo, which would have called into question the grants authorized by the Texan government. Ultimately, however, the majority of Mexican land dispossession occurred as a result of racism and violence. Poet Gloria Anzaldua powerfully describes this oppressive process: 
"The Gringo, locked into the fiction of white superiority, seized complete political power, stripping Indians and Mexicans of their land while their feet were still rooted in it...we were jerked out by the roots, truncated, disemboweled, dispossessed, and separated from our identity and our history." 99

In California, Mexican landholders were sometimes dispossessed because they did not have the resources to legally defend their titles. Griswold del Castillo highlights that Californios were often forced to mortgage their ranches in order to finance these funds, and "Falling cattle prices and usurious rates of interest conspired to wipe them out as a landholding class." 100 Similar forms of physical and economic violence towards Mexicans occurred across the newly acquired territories, with a clear goal of accumulating more land for Anglos. Land was taken through various coercive tactics, including the declaration of debt/tax repayments, fraud, abusive legal maneuvering, and outright intimidation and theft. The result was the proletarianization of many Mexicans, to reduce them "to the status of landless workers dependent for their livelihood on agricultural wage labour."101

This violent process of accumulation by dispossession was part of an effort to institutionalize private property. While Spanish colonization sought to replace the ejido ${ }^{102}$ -an institution of communal land - with the encomienda system, Hernandez highlights how the ejido was still very much a part of Mexican social relations. She discusses how the transfer of land from Mexicans to Anglos redefined how land was conceived and used:

The change of land ownership from Tejano to Anglo, whether it was a rapid process or a gradual one, had an impact on the traditional view towards the land. Since before the establishment of the rancho system in South Texas, Mexicanos viewed their land as something sacred, and indeed as part of their lives. In particular, the South Texas Tejanos viewed their land tracts as 'non-commercial entities' and as 'life sustaining 
gifts.' Moreover, land grants had been based on the Spanish indigenous policy of giving communal ejidos. Gradually, this view towards land as part of the individual changed when it came under Anglo ownership. ${ }^{103}$

The forceful institutionalization of private property in the US-Mexico borderlands during the 1800 s is thus a continuation of the theft and violence witnessed during Spanish colonization. Resistance emerged, and the borderlands would be increasingly defined by an American pacification project.

Dunn highlights how this period and the 70 years that would follow were particularly violent times for the border region, characterized by "massive repression" towards Mexican insurrection against land confiscation. This era "can be viewed as an attempt on the part of US officials as well as Anglo settlers and elites to pacify, or subdue, the Mexican American population residing in the border region." 104 The border region was defined by an ongoing struggle between Mexicans and Anglos, and when necessary, the US military would intervene.

During the Cortina War (1859-1860), US troops alongside the Texas Rangers repressed resistance from Tejanos in the Lower Rio Grande Valley, who were angered by Anglo racism, widespread killing, and land theft. ${ }^{105}$ Land dispossession continued in this region into the early twentieth century. In 1915, coinciding with the Mexican Revolution (1910-1920), Texas Mexicans in the Lower Rio Grande Valley rebelled against what the Plan de San Diego ${ }^{106}$ called "Yankee tyranny," performing raids against Anglo ranches and other targets. Anglo Texans responded ruthlessly, with Texas Rangers and vigilantes carrying out a counterinsurgency that involved forcible displacement and mass executions. ${ }^{107}$ According to Johnson, "Respectable citizens openly made statements of near-genocidal racism." 108 1,900 US Army troops were sent into the valley to pacify the 
rebellion. ${ }^{109}$ The struggles of the border region led to the establishment of US army forts along the borderline, a space that would become only more militarized over time.

When northern Mexico was ceded to the United States, a dehumanization of the Mexican justified the mass theft of land and the conquest of peoples. Yet once incorporated into the American state, assimilation was also at play. Article 9 of the Treaty of Guadalupe called for conquered Mexicans to give up their Mexican character: "The Mexicans who, in the territories aforesaid, shall not preserve the character of citizens of the Mexican republic." ${ }^{110}$ According to some scholars, ${ }^{111}$ this can rightly be understood as a direct assault on the Mexican identity. For Mexicans residing in the occupied lands, "Becoming a U.S. citizen requires the loss of a Mexican character that is both national and racial." 112 Enshrined in the treaty, this language is reflective of the state's project of nation-building that, among its goals, seeks to whiten the nation. Yet "it is nevertheless impossible for them to shed this character, as it is biologically tied to their mixed racial character in the eyes of Anglo governmentality,"113 which utilizes racial codifications when advantageous.

Whether appealing to assimilative ideas or racial divides to carry out colonialism, race was used as a tool of domination in the construction of the US borderline. It should also be noted that gendered violence commonly occurred during the Anglos' direct assaults on Mexican farms and families. Historically and in the contemporary security regime, sexual violence is a common tactic of intimidation and domination, and a common feature of colonialism. 


\subsection{Conclusion}

The historic shaping of the US-Mexico borderline involved the violent appropriation of resources, giving rise to Mexican resistance and ultimately resulting in an increased militarization of the borderlands. As Foucault notes, the apparatuses of security "have the constant tendency to expand." 114 These spaces are becoming increasingly securitized culminating in the construction of the US-Mexico border security wall and fences. Through this historical analysis, we see that the roots of the wall can be traced to the implementation of the American colonial project. The border is a social construct to be enforced, thus contextualizing how militarization -as pacification -is necessary to dominate the contested spaces of the borderlands and the peoples that reside there. The Mexico-US border security wall today maintains the territorial designations established during American expansionism, and thus facilitates neocolonialism through maintaining colonial spatialities. Through engaging in a process of racialization that can be traced to American colonization, which will be explored in further detail throughout this thesis, the wall is further implicated in neocolonial relations.

Given that the Israeli colonization of Palestine is ongoing, the wall in Palestine can more directly be tied to colonial goals. It is actively engaged in a process of accumulation by dispossession through demarcating space in a way that facilitates the dispossession of land and resources from Palestinians. While the wall arose in response to the Second Intifada, the empirical evidence presented in this chapter demonstrates that the wall performs clear economic functions in support of Israeli colonialism, which has systematically targeted the spaces that Palestinians reside in. 
Mapping out and enforcing particular lines and boundaries is necessary for land appropriation and the generation of capital. The colonization of Mexican and Palestinian lands have entailed a forceful imposition of capitalist social relations. While the foundations of capitalism evidently have violent roots -playing out across spaces of resistance -the advancement of capitalist economic relations have given rise to a greater securitization of borders, and the erection of security infrastructure, notably walls and fences, in order to affirm the colonist's spatial designations of the borderlands. 


\section{Chapter: Constructing Exploitation and Stratifying Labour}

\subsection{Introduction}

In this chapter, I outline how border security walls construct conditions for labour exploitation and develop racially stratified social relations in the labour market. I look at how the walls in Israel-Palestine and the US and Mexico form a component of a much larger regulatory infrastructure to accomplish these functions. In the case of Palestine, the wall is part of a complex pass and permit system that stifles human movement and controls Palestinian labour through restricting access to the labour market. It works in conjunction with various state laws that privilege Israeli workers. In the case of Mexico/US, the wall operates in conjunction with temporary foreign worker programs that limit workplace rights and establish frameworks that set the conditions for intensified exploitation in the workplace.

In the Palestine case study, I explore how exploitability is constructed through the manufacturing of illegality in the advancement of a sanctioned/unsanctioned labour regime. It is further developed through the symbolic and material processes of the wall, which exacerbate vulnerabilities present among a population living with the realities of occupation, economic instability, and enclosure. I explore how the wall destabilizes the Palestinian economy, and I discuss intersections between class and race in the context of the Israeli-Palestinian labour economy. I present the term 'superexploiation,' as employed by Josiah Heyman, to describe the conditions of Palestinians in the labour market. I discuss how the wall engages in this process of 'superexploitation.'

The second section of this chapter begins by providing an overview of legislation and programs in the United States that facilitate the entry of temporary foreign workers 
into the country, highlighting the state's overall historic preference, beginning in the 1900s, for flexible and disposable migrant labour that can be easily surveilled. I introduce the term 'precarious legal status,' coined by Goldring et al., to explain how racisminfused public hysteria surrounding undocumented labour can contribute to the marginalization and exploitation of all racialized workers. I describe how the fences fortify the spatial parameters of a wider disciplinary regime, and I argue that the wall and fences increase the state's capacity to manage its workers. The border security walls in Israel-Palestine and the US and Mexico perform various material, psychological, and social processes that facilitate increased exploitation in the workplace, and contribute to the formation of a stratified labour market.

\subsection{Historicizing stratified labour in Israel: the 'superexploitation' of Palestinian workers}

Palestinians have been subjected to a long history of economic marginalization. Since declaring statehood in 1948, Israel has continually invested in the economic development of primarily Jewish localities, to the exclusion of Palestinian regions. Large-scale confiscations of land from Indigenous Palestinians have effectively led to their proletarianization. Various state practices have historically privileged Jewish Israeli workers, creating a racially-stratified labour market in Israel.

The wall, which physically regulates the movement of Palestinian workers, should be conceived as one facet of Israel's regulatory regime. Its effectiveness as a tool of regulation is due to its intricate interaction with other Israeli-manufactured barriers, including a complex and restrictive labour permit system. Israel's checkpoint system, 
now fortified by walled infrastructure, has increased the costs and risks associated with economic activity in the OPTs, impacting levels of trade and investment. State policies of targeted Jewish development, alongside the systemic discrimination of Palestinians in the workforce, have contributed to the marginalization of Palestinians and the Palestinian economy. Through regulating Palestinian labour, the wall helps to facilitate the 'superexploitation' of Palestinians for the benefit of the Israeli capitalist class. Yet both working and wealthy Israelis are able to benefit materially from this discrimination. In the labour hierarchy in Israel-Palestine, Palestinians sit at the bottom. It is also important to note that the division of labour under capitalist colonialism is profoundly gendered.

Israel's segregationist policies, affirmed both materially and symbolically by the wall, stifle solidarity between Israeli and Palestinian workers. And while both the introduction of the permit system and the erection of the wall were politically motivated maneuvers, these policy decisions, rooted in Zionist ideology, have had intentional economic impacts. It is worthwhile to examine how particular structures of domination in this case, racial domination -constructs a division of labour that produces real material benefits for economic elites.

Josiah Heyman employs the term 'superexploitation' to denote the severity of exploitation experienced by undocumented labour in relation to other forms of exploited labour: "compared to the normally exploited, resourceless proletarians (day labourers, farmers, domestics, etc.), undocumented immigrants work faster and harder for the same pay... and struggle to avoid or limit workplace authority less often." ${ }^{115}$ In Marxist theory, exploitation is understood to occur when the capitalist extracts surplus value from the labour of the worker. The concept of exploitation is intimately tied to alienated labour. 
Marx understands alienated labour as the realization of labour, then its objectification and appropriation by the capitalist. ${ }^{116}$ While exploitation and alienation are inherent to capitalist economic relations, 'superexploitation' is a useful term to understand how the exploitation of Palestinian workers differs from that of Israeli workers. While all workers face discipline, Palestinian workers are subject to more severe disciplinary mechanisms than their Israeli counterparts. While all workers are subject to surveillance, Palestinian workers undergo its more pervasive forms. The 'superexploitation' of Palestinians is constructed through other processes of regulation. The permit system has created a system of sanctioned/unsanctioned labour, thus criminalizing Palestinian workers that have not received formal authorization to work in Israel.

In the year 2000, before the Second Intifada, the number of Palestinians from the occupied territories working in Israel peaked at $96,000 .{ }^{117}$ This figure drastically declined to 30,000 in 2002 as a result of Israel's increasing efforts to implement a separation policy. ${ }^{118}$ It was during this period that the wall's construction efforts intensified, and a continuous barrier along the border was formed. These changes were implemented within a climate of economic instability and rising unemployment among Israelis.

In 2011, according to the Israel Central Bureau of Statistics, there were 34,300 permanent or temporary documented workers from the OPTs working in Israel. ${ }^{119} 48$ percent of these workers worked in construction, an industry known for its precarious working conditions. ${ }^{120}$

The systemic discrimination faced by Palestinian citizens in the Israel labour economy stems from Zionist ideologies. Framing Israel as the homeland for all Jewish people, the Zionist project seeks to build the Jewish population in Israel. In order to limit 
Jewish emigration, state policies have sought to minimize Jewish unemployment and increase standards of living, often at the expense of Palestinians. "Securing full employment [of Jewish people] has been a prime socio-economic strategy that all Israeli governments have pursued." ${ }^{\text {121 }}$ While the creation of a race-based division of labour has immensely benefited Israeli employers through constructing Palestinian labour as 'superexploitable,' Jewish workers have also gained from practices of exclusion and discrimination. Established in 1920, The Histadrut (the General Organization of the Hebrew Workers in the Land of Israel) was a trade union that actively pursued the 'Hebrew Work' campaign, which advocated for the privileging of Jewish workers and Jewish-owned companies in both the public and private sector. ${ }^{122}$ Similar class disunity can be seen in nationalist trade unions in North America, which advocate for the protection of American and Canadian jobs against immigrant work.

In response to growing unemployment after 1982, the state of Israel instated the Discharged Soldiers Law in an effort to further privilege Jewish people in the workforce. The law prioritized discharged soldiers for acceptance to universities and occupational training opportunities. It furthermore gave former soldiers privileges in accessing educational loans and subsidies. ${ }^{123}$ With minor exceptions, ${ }^{124}$ nearly all Jews are conscripted to the Israeli army. This is not the case for Palestinian citizens in Israel. ${ }^{125}$ This law directs the state's limited resources to Jewish people and improves their access to the job market.

The Absorption of Discharged Soldiers Law, first enacted in 1994, was amended in 2010 to grant additional education and housing benefits to discharged soldiers, including a year of free tuition. These are just some of the many institutionalized 
measures in place that facilitate a division of labour between Israeli Jews and Arabs, and ensure the economic exploitation of Palestinians in the Israeli labour market. In 2011, Israeli Attorney General Yehuda Weinstein echoed these sentiments when he urged Prime Minister Benjamin Netanyahu to stop the advancement of a bill ${ }^{126}$ that would give discharged soldiers preference in obtaining jobs in the civil service. As reported in the Israeli newspaper Haaretz, Weinstein stated that "Affirmative action is for underprivileged groups that need support and assistance, not for the majority." He argued, "This bill is directed against Arabs, Christians, Druze women and the ultraOrthodox. It stems from a racist worldview among people to whom the principle of equality is alien."127

While Palestinian citizens in Israel not only face greater barriers to accessing work than their Jewish counterparts, they are also more likely to have lower paying jobs and more precarious employment. As second-class citizens in Israel, they do have access, at least formally, to some social and political rights. The same cannot be said for Palestinians in the OPTs, who, as a labour reserve for Israel, face similar conditions of exploitation experienced by other migrant workers in Israel and throughout the world. ${ }^{128}$

\subsubsection{Israel's work permit system}

In 1991, Israel introduced a work permit system that required Palestinians to obtain a work request from an Israeli employer in order to access the labour market in Israel. It furthermore required Palestinians to obtain approval from the IDF. There were greater restrictions placed on workers seeking work in Israel proper compared to those seeking work in the settlements. ${ }^{129}$ The work permit system was accompanied by a pass 
permit system, requiring Palestinians to obtain a permit simply for travelling between Palestine and Israel proper. It is important to note that since Israel's formal withdrawal from Gaza in 2005, only Palestinians from the West Bank are able to cross into Israel. ${ }^{130}$ The new work permit system would create a relationship of dependency between Palestinian workers and their employers, and give the military a greater role in regulating Palestinian movement. ${ }^{131}$ As both the permit and closure systems have heavily restricted authorized labour, many Palestinians workers in Israel are undocumented. Although these figures are difficult to quantify, Cohen suggests that in the early $21^{\text {st }}$ century, 70 to 80 percent of Palestinian labour in Israel was unsanctioned. ${ }^{132}$ Undocumented workers are vulnerable to severe forms of exploitation because they cannot pursue legal protections in the workplace without facing detection.

The wall, which projects a notion of criminality onto Palestinians, can exacerbate the sense of vulnerability experienced by Palestinians. Avram Bornstein hypothesizes that "military or police violence and surveillance, deployed by the state, buttress economic violence by making workers more vulnerable. Perhaps the Border Patrol is not intended to prevent the entry of workers, but is a way of disciplining them to work hard and to accept low wages." ${ }^{\prime 33}$ The disciplining and intimidation of workers are part of the wall's social and symbolic functions. Imitating a mass open-air prison, the wall sends a clear message to Palestinians: You are a criminal, and you are vulnerable. The structural privileging of Jewish workers, the permit system, and the development of conditions for undocumented labour in Israel have created the conditions for 'superexploitation.' The wall interacts with the work permit system to facilitate exploitation through increasing 
the state's capacity to control movement, and force adherence to the system of labour regulation in place.

\subsubsection{The wall's role in destabilizing the Palestinian economy}

The wall marks a broader effort to shrink Palestine's economy and generate a sense of vulnerability among Palestinians. Both the wall and the checkpoint system in Palestine have had clear negative impacts on the Palestinian economy. Both have stifled movement and have posed barriers to trade and commerce. The wall, 85 per cent of which strays from the 1967 green line, has enclosed 46 Palestinian villages between the two lines, limiting access to the rest of the West Bank. ${ }^{134}$ It nearly completely encircles the town of Qalqilyah. Following the completion of the wall dividing Jerusalem and Ramallah, 400,000 Palestinians have been segregated from adjacent towns. ${ }^{135}$ Thus, not only does the wall impact Palestine's economic relations with Israel, it also harms trade within Palestine. In some instances, the wall has divided farmers from their own crops and land, not merely their consumers. Agriculture is the sector most harmed by the barrier. ${ }^{136}$ While commercial trade has been deeply affected, it's construction has had further material repercussions for Palestinians: the destruction of property; the degradation of the environment, including agricultural land and water resources; and the confiscation of land. In fact, the wall appropriates 11 percent of land in the West Bank for the wall's own direct use, in addition to its appropriation of land for settlement. ${ }^{137}$ The wall, as a fundamental component of a broader enclosure system, is responsible for vast economic hardship: "the primary factor destabilizing the economy is the system of closure."138 Border security plays an active role in regulating the Palestinian economy. Avram 
S. Bornstein writes, "The border can restrict imports and exports, and selectively allow or deny entry to people, thus, influencing international relations of production. Borders also separate the point of production from the point of labor's reproduction." ${ }^{139}$ The wall enables Israel to better control Palestine's economy through directing flows to its entry points, which filter people and goods accordingly. In July 2008, the wall had 66 gates that opened and closed sporadically. ${ }^{140} 19$ were located in places that divided farmers from their agricultural land. ${ }^{141}$ While the gates occasionally opened, in some cases farmers were unable to obtain the necessary permits to actually access their land. ${ }^{142}$ The wall's unpredictable border guards and the heavily bureaucratized and somewhat arbitrary permit system perform filtering functions that have inevitable economic implications. Bornstein highlights that "border enforcement is an important mechanism in processes of domination and exploitation." ${ }^{\text {"143 }}$ If Palestine's economy is weakened, the livelihoods of Palestinians are threatened. Many Palestinians have either migrated or been displaced as a result. Others have pursued work in Israel proper, where working conditions remain precarious for Palestinians.

\subsubsection{Race and class stratification under Israeli colonialism}

Class remains an important lens with which to understand not only the accumulation of wealth under capitalism, but also the impacts of Israel's colonial project on racialized Palestinians. While collectively Palestinians have been subjugated as a people, a class hierarchy is still present, which shapes how one is affected by the occupation. For example, clear economic disparities exist between most Palestinians and Palestinian political elites, specifically those occupying positions within the Palestinian Authority 
(PA). ${ }^{144}$ The PA has been criticized for acting as an arm of the Israeli occupation, particularly for its role in pacifying Palestinians via the policing apparatus, given its role in the oversight of policing institutions in designated areas within Palestine. Class-based alliances transcend national borders. Furthermore, while Israel's colonial project has brought material benefits to Israel's ruling class, it has also privileged its working class, which benefits from better jobs and lower unemployment rates at the expense of poor Palestinians. These realities speak to the significance of race-based and national unity in processes of exploitation, which can generate popular consent for colonialism, while highlighting the way in which class intersects with racialization in a complexity of ways. Yet as a result of the wall, the occupation, and the destabilization of the Palestinian economy, a racial stratification of labour remains present in Israel proper.

\subsection{The Historical Development of Regulated Migrant Labour: immigration policy as a tool for exploitation in the United States}

Immigration policy and the relative permeability of the border has primarily been determined by the nation's need for labour, depending on the state of the economy and the demands placed on government by business. While ensuring a steady labour supply is important, there are other complexities that affect the direction of these policies. While an abundant supply of labour suppresses wages and increases profits, other political and economic conditions can further construct labour as exploitable. The citizenship regime is a tool that has been established throughout the West to create a global stratification of labour. The construction of borders and the regulation of access to national spaces normalize the citizenship regime and its exclusions. The security fences in the US and 
Mexico dictate which spaces one is entitled to access, and who is and isn't included in the national community. The fences, in one sense, are a sign of political and economic might, with the state institution using its power to intimately shape the economic, social, and spatial conditions favourable for profit generation. However, immigration policy and border security is not solely directed by a profit motive; other factors intimately affect the type of legislation developed by the US congress and senate. This includes, "various combinations of racism, fears of tax increases, cultural and political protectionism, and organized labour's concerns over bargaining power," which all may contribute to a sense of anti-immigrant nativism in the United States. ${ }^{145}$

To understand the role of the border fences in regulating labour -and by this I mean maintaining authority over it - and constructing exploitation, it is necessary to contemplate how immigration policies have evolved over time. Consistently throughout the $20^{\text {th }}$ century, the United States has sought to regulate movement as a means of controlling labour. This supports the state's preference for temporary foreign work, whereby workers are afforded less rights in the workplace and are more susceptible to surveillance, discipline, and isolation, and are thus ultimately more exploitable. What programs have developed that enable these conditions, and how does the wall function amidst these programs?

Dunn notes that pacification of the border regime was finally accomplished in the 1930s following 80 years of conflict. ${ }^{146}$ In 1924, the United States Border Patrol was established, which notably was an agency of the US Department of Labour. From 19001930, Mexicans migrated on mass to the US. Approximately 685,000 immigrated legally. ${ }^{147}$ This was facilitated to satisfy American employers' need for cheap labour, 
following advancements in agriculture, mining, and the railroad sectors. ${ }^{148}$ In the nineteenth century, most US agriculture operated with family labour, but with the development of the transcontinental railroad, the market for fruit, vegetable and horticultural production expanded, creating a reliance on seasonal wage labour. ${ }^{149}$ In the 1930s, in the midst of the Great Depression's high unemployment rates, Mexicans were scapegoated by the public and deported on mass, and their properties were seized and stolen. ${ }^{150}$ When the US entered the Second World War, the American economy again saw a labour shortage. In 1942, the US and Mexico negotiated the establishment of the Bracero Program. The program would facilitate the importation of over 4.5 million Mexican migrant workers until its demise in $1964 .^{151}$

The Bracero Program is a stark example in US history that demonstrates the state's ongoing attempt to regulate but not limit labour. It was a guest worker program: workers were expected to return home at the end of their contracts. They were guaranteed back pay after returning, which in reality many never received. In numerous capacities, workers were heavily abused and exploited. While the program established minimum wage standards, employers often ignored them. The nature of the program ensured that Mexican workers would form a steady supply of low-paid labour that would drive down wages. As the largest guest worker program in US history, "the scope of the Bracero Program vividly illustrates the involvement of agricultural interests in the design of immigration policy to increase the farm labour supply." 152 The program, when analyzed alongside Operation Wetback, speaks to how Mexicans have been incorporated into the US over time: as exploitable and disposable. 
Operation Wetback, carried out in 1954, oversaw the mass deportations of undocumented Mexican migrants. "It was the first large-scale, systematic implementation of military strategy and tactics by the INS against Mexican immigrant workers." ${ }^{153}$ While the US sought to increase the flow of regulated workers through the Bracero Program, in sharp contrast, undocumented immigrants were targets for expulsion. Border Patrol agents conducted mass round-ups in targeted areas, sweeping across the borderline. ${ }^{154}$

Dunn notes that the Border Patrol "had a definite and consciously constructed paramilitary character," ${ }^{155}$ effectively intimidating migrants. Operation Wetback would ostracize Mexicans from the US social body. It was "an assault on the dignity of Mexican immigrants and of Mexican-origin people more generally," generating a social climate that would make it more difficult for workers in the Bracero Program to resist exploitation. While the 1940 s to 1960 s mark a period when "the INS was a complaisant tool of agribusiness, which had entrenched power in the US Congress," ${ }^{156}$ it was also a period of penetrating racism against Mexicans, exacerbated by the hostilities they faced from American workers that scapegoated them for suppressed wages. But "the INS efforts directed towards the growers illustrate the true purpose of Operation Wetback, and of the INS enforcement activities in general: to regulate and shape the flow of Mexican immigrant labour -not to prevent it."157

A regime of regulation increases the state's capacity to discipline workers and exercise power over them. As Foucault states, "the phenomenon of a social body is the effect not of a consensus but of the materiality of power operating on the very body of individuals." ${ }^{\prime 58}$ This, in essence, describes the nature of regulation, which, at the border, targets the movement of the body. 
For the capitalist state, poor bodies are threatening bodies, and are thus targets of social control. Migrant workers, who are part of the poor working class, are thus susceptible to a state regime of regulation, which we see supported through state policies that favour documented temporary foreign work. The border security wall is an architectural component of this regulatory regime.

The temporary foreign worker with status, although not criminalized individually, may face collective criminalization based on racial identity. They are frequently subject to racial profiling by security forces. And due to their reduced rights as temporary workers, and a lack of effective enforcement of these reduced rights, they are subject to differing forms of exploitation and discipline. Thus, rather than incorporating migrants fully into the national community or conversely denying them entry, the preferred model in Western nations has been to promote and expand temporary foreign work, which enables greater regulation and surveillance of workers in general.

In 1986, the US government passed the Immigration Reform and Control Act (IRCA), which "inaugurated the strategy of greater reliance on the importation of temporary workers, with the aim of satisfying the new needs of employers, but avoiding the settling of such workers permanently within the country." 159 The act would give some undocumented workers -those in the country before 1982, and seasonal agricultural workers that worked a minimum of 90 days prior to May 1986 - lawful permanent residency. In this regard, the act was considered a victory for undocumented workers in the US. However, it also "reflected an attempt to increase border controls," 160 and it increased the capacity of the state to manage workers, given the influx in temporary foreign workers documented by visa programs. According to Calavita, the IRCA "can 
best be understood as an effort to respond simultaneously to the longstanding economic reality of undocumented immigration and to the political reality of increasing restrictionism."161

Contract workers would again be a crucial component of the labour economy, and this is still the case. Between 1990 and 2008, the number of temporary foreign worker visas increased from 144,680 to 943,431 , marking a seven-fold increase. Meanwhile, the number of working immigrants admitted grew at a much lesser rate, from 58,192 to $166,511 .^{162}$ This demonstrates the extent to which the government has favoured temporary foreign work over permanent immigration. The US's policy preference for temporary foreign work marks an effort to balance the needs of employers with heightening the state's capacity for social control. Fundamentally, this model facilitates heightened exploitation, and the border security fences serve these ends.

\subsubsection{H2 Visas: the institutionalized exploitation of temporary foreign workers}

In 2004, and again in 2006, President George W. Bush proposed that a new guest worker program be established that would allow undocumented workers residing in the United States to apply for a three-year temporary work permit. This again marked a concerted attempt to increase the state's capacity to monitor those within the territory. In 2006 , Bush stated publicly, "Our Government must enforce our borders; we've got plans in place to do so. But part of enforcing our borders is to have a guest worker program that encourages people to register their presence so that we know who they are."163 An economic motive was also clear: "If you're doing a job an American won't do, you're welcome here for a period of time to do that job." ${ }^{164}$ Bush played the tune of his 
predecessors: migrants are welcome so long as they are willing to perform precarious work and submit to the regulatory controls of the security apparatus. While the proposal, entitled the Comprehensive Immigration Reform Act of 2006, ultimately died because it could not be passed by the US House of Representatives, it did successfully pass by a large majority in the US Senate. This speaks to the influence of economic interests in US politics, however confronted by anti-immigrant nativism. Yet nonetheless, President Bush pushed a political agenda that invited an increase in documented temporary foreign work, and by extension, an increase in regulated labour. This corresponds with what Calavita identifies as a "longstanding perception of Mexican migration as a flexible and temporary supply of labour."165

In the US, $\mathrm{H} 2$ visas are the common system under which temporary foreign work operates. They were initiated in 1943 to meet the needs of the sugarcane industry. ${ }^{166}$ They allow a non-citizen entry into the US for the purpose of temporary or seasonal work. From its beginnings to now, the program has acted as a service for employers. The employers must submit a request for workers, and the program responds to these needs. In the 1980s, the visa was divided into two categories: H2A visas for agricultural workers, and $\mathrm{H} 2 \mathrm{~B}$ visas for non-agricultural workers.

While there are some small differences between the rights afforded to each class of workers, each visa standardizes exploitative conditions. In each case, workers are bound to a single employer. The worker does not have the right to quit her job. If an employer fires a worker or cancels a contract, the worker cannot stay in the country, and at no point during her stay is she entitled to apply for permanent residency. This 
relationship of dependency severely restricts workers' abilities to dissent in the workplace, and essentially extinguishes their capacity to claim their rights.

Furthermore, workers of the $\mathrm{H} 2$ visa program do not have the legal right to collectively bargain. ${ }^{167}$ This marks an outrageous attack on organized labour and the labour movement as a whole, which has faced a declining unionization rate in the United States for decades, partially as a result of draconian anti-union laws adopted across states. This disgraceful component of the program works to construct a more exploitable class of workers in the United States, a class that is continuously expanding as a result of immigration policy. This exerts downward pressure on workers' wages everywhere.

$\mathrm{H} 2 \mathrm{~A}$ visas place certain obligations on employers. They are required by law to pay the same wage received by US residents. They must provide the worker transportation between contracts, and they must provide adequate housing and agricultural tools. ${ }^{168}$ These same benefits are not provided to $\mathrm{H} 2 \mathrm{~B}$ workers, who oftentimes must pay expensive travel costs to access work. However, legal enforcement of these minimal obligations is quite weak. There are an insufficient amount of inspectors, and $\mathrm{H} 2 \mathrm{~A}$ workers are often in remote locales, isolated from the authorities. ${ }^{169}$ Access to legal services is extremely limited, and freedom of movement is strictly controlled. These conditions readily enable abuses to occur.

H2B workers have less formal legal protections than H2A workers. The only guideline established by the IRCA that addresses pay standards is that the workers "should have no adverse effect on local workers, either on salaries or on working conditions." 170 The Department of Labour accepts the rate declared by the employer. 
Although, it should be noted that H2B workers are covered under the Fair Labour Standards Act, which establishes a national minimum wage.

The everyday rights and protections offered to US-born workers do not apply to $\mathrm{H} 2$ visa holders. This relationship of exploitation is only further exacerbated by the introduction of recruitment agencies, which charge workers upwards of 500 dollars to receive work placements. ${ }^{171}$ In some cases, workers have reportedly paid nearly 5,000 dollars to finance the costs of recruitment, transportation, and visa fees. ${ }^{172}$

Temporary foreign worker programs enable the government to regulate just who is entering and leaving the country, while employers are still provided with highly exploitable labour. Temporary foreign workers thus form a reserve army of labour for United States' employers, who may access labour in accordance with their fluctuating needs. The program also constructs labour as disposable, given that workers are not entitled to stay in the country, as in the case of the Bracero Program. The fences pronounce to migrants that access to the country can only be granted through participating in such programs, thus contributing to the exploitability of migrant workers and a racial stratification of the workforce. I expand on this further in the upcoming section, whereby I examine the role of the wall in disciplining workers to accept conditions of exploitation.

\subsubsection{The fences and the disciplining of undocumented workers}

The guest worker model does not necessarily conflict with the state's limited tolerance for undocumented workers. Constructing a regime of regulation necessitates the 
concurrent 'illegalization' of migration, which justifies the ballooning of security and policing.

Generating public hysteria around undocumented labour creates suspicion and hostility towards all foreign workers, who, while legally sanctioned to work in the country, may still face what Goldring et al. term 'precarious legal status.' This describes "the various forms of non-citizen and non-resident status... It also conveys a combination of ongoing risk and uncertainty, or ongoing vulnerability to precariousness, because it connects to the literature on precarious employment." ${ }^{, 173}$ This concept rejects a dichotomous approach to citizenship, which does not adequately encompass the realities of fluctuating and 'liminal legality' faced by temporary foreign workers and other individuals positioned precariously in the citizenship regime. ${ }^{174}$ Given the racialized nature of 'precarious legal status,' a culture of racism can empower employers. The fences, in their domineering physical authority, reproduce public hysteria and racism. This culture of racism empowers employers, whose injustices against Mexicans and other foreign workers -sanctioned or otherwise - become more socially tolerable.

Allowing a controlled presence of undocumented labour in the United States is economically beneficial because it is 'superexploitable.' Heyman hypothesizes that the state may construct 'superexploitable' labour precisely because it drives down labour costs. And while the state still serves, to an extent, as a site of struggle for various social forces, the interests of capital have historically been represented by the US state. Thus, government policies and practices that discipline the 'superexploitable' worker are observable:

The state might deliberately create a category of vulnerable and fearful workers. Undocumented status, involving denial of rights to settle in the US, 
might function to regulate the costs of labour reproduction to Mexico and other nations. Illegal border crossings might discursively discipline undocumented immigrants to be subordinate outsiders in a citizenship-based national-state. $^{175}$

The wall, militaristic in nature, carries out a disciplinary function through characterizing the border spaces as aggressive, hostile and possibly violent. Experiencing the wall as an outsider -either through a sanctioned or unsanctioned border crossing -has pacifying effects. Thus, it comes as no surprise that the construction of the border security wall is part of a program of disciplining undocumented migrants. The border security wall does not need to fully eliminate undocumented migrants' access to the territory in order for it to be an effective mechanism of control.

In 1996, in another attempt to regulate workers, the government adopted the Illegal Immigration Reform and Immigration Responsibility Act (IIRIRA), what Ackleson refers to as the "landmark authorization for border securitization." 176 It mandated the construction of a triple wall along certain border zones, increased two-fold the number of border patrol officers, and implemented a computerized fingerprinting system. ${ }^{177}$ Given that the fences have been erected as part of an immigration control strategy, their role in securitizing the border is linked to the purported 'risks' posed by immigration. But ultimately, the fences serve to intimidate undocumented migrants while supporting a system of regulated labour.

The IIRIRA actively targets undocumented and documented migrant labour. In addition to facilitating the deportation and expulsion of unsanctioned migrants staying in the United States, it afforded additional grounds for the deportation of documented migrants who had been convicted of criminal activities, including minor, non-violent offences. ${ }^{178}$ But as Coutin notes, citing De Genova (2002), anti-immigrant legislation “is 
designed less to produce deportations than deportability," exacerbating in migrants a sense of insecurity. ${ }^{179}$ This marks an attempt to pacify both sanctioned and unsanctioned migrants, a category of workers that face greater penalties for exercising social dissidence. For undocumented workers in the US, this legislation increases their vulnerability because the consequences of detection become more severe. Thus, workplace abuses are more likely to go unchallenged, and a greater surplus value can be extracted from their labour. In this light, we see how the security apparatus, within the logic of pacification, shapes "the behavior of individuals, groups, and classes, and thereby ordering the social relations of power around a particular regime of accumulation." ${ }^{180}$ Undocumented workers face greater discipline for 'crimes' committed than their American counterparts, who are not under threat of deportation for committed the same crime. Those that are not assimilated peacefully into the social order can be pacified through deportation, in accordance with how officers choose to apply the law.

Under the Obama administration, deportations and detentions have dramatically increased. ${ }^{181}$ While immigration enforcement was traditionally under the domain of the federal government, prior to 2006, Gardner II and Kohli report that the Immigration and Customs Enforcement (ICE) agency has since more frequently partnered with local law enforcement bodies. ${ }^{182}$ These local enforcement agencies, many given access to the Department of Homeland Security's databases, have proceeded with removal measures without consultation with the ICE. Gardner II and Kohli point to grave concerns of an increased racial profiling of Hispanic persons as a result of these developments. This signifies increased risks for those with precarious legal status residing in the US, and speaks to the heightened capacity of the state to criminalize migrants. 
As territorializing agents, the fences fortify the spatial boundaries of the disciplinary regime. As Foucault notes, "Discipline functions to the extent that it isolates a space, that it determines a segment. Discipline concentrates, focuses, and encloses. The first action of discipline is in fact to circumscribe a space in which its power and the mechanisms of power will function fully and without limit." ${ }^{\prime 183}$ The fences thus mark an effort to increase the state's capacity to surveil, and by extension, manage its workers. These manifestations of power limit an individual's capacity to resist exploitation, particularly through methods that extend beyond the scope of legal permissibility.

\subsubsection{The border as the 'edge of the citizen-self'}

The exploitation of temporary foreign workers and undocumented migrants is intrinsically tied up in several factors relating to one's social positioning in society: the actual rights afforded based on status, repressive mechanisms that discourage the exercising of rights, and one's sense of belonging, which can empower an individual to claim rights based on the support mechanisms perceived to be in place. Thus, the symbolic effects of the border security wall can have psychological implications for migrant workers, which can increase their exploitability. Referencing Calavita, Heyman states, “"symbolic politics' pervade US immigration policy." 184 Notably, he affirms that "the most important symbol is the border, especially the boundary with Mexico. The border is the edge of the citizen-self." 185 The wall performs the symbolic function of demarcating the citizen from the non-citizen in accordance with spatial, racial, and national configurations. When migrants surpass the border wall, the architecture signals to them that they have now entered a space that is not necessarily 'theirs' -where they 
will not be accepted as fully recognized members of society. The border's militarized infrastructure is aggressive and unnerving, symbolizing the hostility that awaits outsiders. For American citizens, the symbolic value of the security wall is very different. It is a symbol of protection, as denoted in the mission statement of the US Border Patrol: "We are the guardians of our nation's borders. We are America's frontline. We safeguard the American homeland at and beyond our borders. We protect the American public against terrorists and the instruments of terror."186 Yet for migrant workers crossing the border, the fences are an extension of policing that targets them because of their Mexican identity. This intimidation is often exported into the workplace. When migrant workers "enter social relations of labour, they carry the border experience with them." 187 Whether documented or undocumented, migrant workers with precarious legal status are still impacted by the symbolism of the border.

\subsection{Conclusion}

Temporary foreign worker programs have dominated US labour policy for the last 100 years, precisely because they provide employers with cheap and exploitable labour to work often dangerous jobs. These programs express a general will for flexible labour, and contracts that can be exterminated when necessary. These programs conflict directly with working class interests, half-heartedly expressed in the goals of organized labour, which has traditionally advocated for adequate wages, health and safety protections, and job security. While the wall in the Mexico-US appeals to anti-immigrant nativism to divide workers and legitimize racialized forms of exploitation, working class people need to 
problematize the structural failures of these programs, which work in tangent with the citizenship regime to suppress the quality of jobs in the labour market.

The border security wall increases the capacity of the state to discipline its workers through limiting their acceptance into a national community of belonging; the symbolic functions of the border, in tangent with the anti-immigrant pursuits of the INS and local law enforcement, pressure workers with precarious legal status to adopt behaviours and practices that render them invisible. This is particularly notable in light of the aggressive racial profiling tactics under the Obama regime.

I argue that the wall increases the state's capacity to exert social control through its surveillance functions. The fences demarcate the spatial boundaries of governance, which is necessary for the execution of power. Exploitation is made possible through various mechanisms of social control, alongside the legislative tools of oppression, particularly embodied in the $\mathrm{H} 2$ Visa system.

Border security plays an important role in controlling the Palestinian economy. The wall has obstructed goods and services from reaching Gaza and the West Bank, and this has had detrimental impacts on the livelihood of Palestinians, generating unemployment and limiting economic opportunities. As in the case of the US-Mexico, the wall, as part of a larger security apparatus, has sought to discipline Palestinians through the construction of criminalities. While Palestinians have rejected these subjectivities bestowed on them, the wall performs repressive functions that facilitate economic exploitation. Israel, as an occupying force, has given the IDF heightened powers in the monitoring of Palestinian movement, and the heavily bureaucratized pass and permit system impedes access to employment. Institutionalized racism, as 
exemplified in such measures as The Discharged Soldiers Law, place Jewish workers in a position of privilege within the market, leading to a racially stratified division of labour. Palestinians, alongside other migrant workers, often work precarious jobs or suffer from unemployment. Although many workers face exploitation in the workplace, these realities underline the racialized nature of class relations in Israel-Palestine, concurrently noting that many Palestinian elites, particularly political elites within the PA, personally profit from the exploitation of others.

The wall, erected by the Israeli state, has separated farmers from their fields, students from their schools, and the injured from hospitals. It has contributed to the destabilization of the Palestinian economy, and constructed the conditions for exploitable Palestinian labour. While the US-Mexico and Israel-Palestine walls engage in very similar symbolic and social processes with similar economic ends, the direct material effects of the Apartheid Wall in Palestine are perhaps more glaring, as the wall continues to violently penetrate the daily activities of Palestinians as part of a strategy of theft, enclosure and exploitation. 


\section{Chapter: Facilitating Uneven Development}

\subsection{Introduction}

While there are clear economic disparities between Mexico, the US, Palestine, and Israel -with economic asymmetry characterizing the border -unequal class relations permeate throughout these nations, in accordance with the contradictory tendencies of capitalism to differentiate and equalize. We witness this contradiction perhaps most starkly in the tendency of capital to permeate virtually every corner of the globe, while relying on the production of inequality to further concentrate wealth. The spatial expressions of capitalism conform to a process of uneven development, meaning, simply, that the centralization of capital is manifested in the environment. The wall seeks to uphold these spatialities.

While geographical inequalities are not strictly defined by nation-state boundaries, the construction of the nation-state and the configuration of its territory is reflective of the way in which the colonial system expanded and accumulated land, ultimately leading to the "spatial as well as social expansion of the domain of wage labour." ${ }^{188}$ In this regard, it is evident how the utilization of space has been essential to the shaping of the relations of production.

Interacting with Israel's checkpoints and permit system, the barrier denotes an isolated labour reserve that can be accessed according to the market's fluctuating needs. The wall, as a regulatory mechanism, helps to spatially solidify inhabitants of the OPTs as a reserve army of labour for the Israeli economy, while engaging in a program of economic restructuring. Marx uses the term 'industrial reserve army' to refer to a surplus population that adapts to the changing needs of capital. Under capitalism, ruling elites 
seek the establishment of flexible and disposable labour markets, whereby we witness "transformations in the spatial and temporal co-ordinates of the labour market." 189 The wall, as a component of Israel's separation policy, has undoubtedly changed the spatial distribution of labour and distributions of wealth.

Likewise, the US-Mexico wall has affected just how labour markets are configured. Throughout the last 100 years, Mexico has been regarded by the US as a source of cheap and exploitable labour, and movement has been facilitated when desired. This has had undeniable impacts on the distribution of wealth -within societies and at a global level. Labour shortages, which generally drive up wages, can be curtailed, and the effectiveness of organize labour within workplaces can be stifled when those with precarious legal status have a restricted capacity to claim workplace rights. These dynamics can affect just how social relations outplay themselves in a capitalist economy. While transnational corporations and their executive officers are much better equipped to overcome spatial barriers, those with less economic privilege are not afforded the same mobility, and this can reproduce spatial concentrations of wealth and poverty. Contextualizing this requires considering the effects of neoliberal development on local and national economies within a process of uneven development.

I argue that the border security wall supports a process of uneven development through fortifying spatialized inequalities, many of which have historical grounding in colonial economic relations. The inequalities inherent to capitalism are not merely illustrated through geography; more notably, space is produced to solidify capitalist economic relations. In part, this entails spatially configuring people as a reserve army of labour for Western economies. 
Finally, in this chapter I interrogate David Harvey's theorizing of neoliberalism, and explore how uneven development occurs within this stage of capitalism. I look at how the allocation of massive public resources into security infrastructure, notably exuberant fencing initiatives, represents a concerted effort to monopolize wealth into the hands of private security firms, and exemplifies neoliberal development due to its instrumentality in the consolidation of class relations.

\subsection{Uneven Development and the Israel-Palestine border security wall}

\subsubsection{Space and the shaping of relations of production in Israel-Palestine}

Since the establishment of the state of Israel, the government has employed various strategies to regulate the incorporation of Palestinian workers -both Palestinian citizens in Israel proper and non-citizens -into the Jewish labour market. From 1948-1966, policy surrounding the granting of work permits to Palestinians was "dictated by the need of the state/Jewish sector for working hands." ${ }^{190}$ This factor commonly determines migrants' access to Western labour markets. In much of Europe and North America, immigrant labour is heavily regulated in accordance with economic trends. In the same way that, through regulation, Western border regimes have constructed reserves of cheap and exploitable labour, Israel's policy of exclusion "converted the Palestinian labour force to a reserve army of labour for the Israeli economy." ${ }^{191}$ According to Marx, the establishment of an "industrial reserve army," also understood as the "relative surplus population," ${ }^{192}$ is a necessary component of capitalism.

The international citizenship regime constructs segmented labour economies, utilizing migrants labour when necessary. Workers in the OPTs form a reserve army of 
labour for Israel so that Israeli business may avoid dependency on a single workforce. According to Marxist geographer Doreen Massey, "location and geographical mobility are key factors in the conflict between labour and capital within production." 193 Spatial separation and the regulation of mobility enables the composition of a workforce to be manipulated accordingly.

During periods of economic growth in Israel, general restrictions on the movement of Palestinian workers were reduced. From 1955-1964, Israel's economy was rapidly expanding, and Palestinian labour was mobilized into blue collar jobs within Israel, particularly within the construction industry alongside increasing investments in infrastructure. Following Israel's victory in the 1967 war, Israel again witnessed a period of economic growth that required the incorporation of new workers into the market. Palestinians from the occupied territories replaced Palestinians citizens as a reserve army of workers. They were used for dangerous, low-paid work, while Palestinian citizens would become "a permanent -but by no means equal -segment of the workforce."194

The current division of labour in Israel-Palestine is rooted in the historical outplaying of capital accumulation, as thrust by colonialism. Smith notes, "The concentration and centralization of capital in the built environment proceeds according to the social logic inherent in the process of capital accumulation, and this, we saw previously, leads towards a leveling of natural differences." 195 'Natural differences' refers to a territorial division of labour rooted in the natural environment. Smith sees "The territorial division of labour increasingly emancipated from its roots in nature." ${ }^{\prime 196}$ The current spatial division of labour is more directly impacted by the development of social relations. In the case of Israel-Palestine, colonial histories have an important role to play 
in the current spatial division of labour - expressed in part in a reserve army of labour which is profoundly affected by the conditions of the built environment.

The wall has further affected social relations through playing a direct role in the destruction of the Palestinian economy. It is widely acknowledged by both academics and international organizations such as the World Bank and International Labour Organization (ILO) that the enclosure system has created economic hardship and instability for the Palestinian economy. The construction of the wall has increased unemployment by 25 percent and decreased exports by 50 percent. ${ }^{197}$ This underdevelopment has been to the benefit of the Israeli economy, demonstrating the role of the wall in processes of uneven development, intimately linked to the development of social relations. The labour force, then, becomes concentrated in specific geographies.

While Palestine harbours its own capitalist class that does indeed have access to capital, capital still remains largely concentrated in Israel. The centralization of capital relies on a concentrated control of resources, including labour resources and natural resources. Both the centralization of capital and the regulation of labour economies are integral to the process of uneven development. Geographical mobility can pose a direct threat to the economic power of different actors. Thus, "mobility and control over mobility both reflect and reinforce relations of power." 198 Yet the wall, which regulates the flow of people and labour into Israel and within Palestine, affects the Palestinian economy in ways that extend beyond this.

Political, social, and economic processes are executed spatially. Various geographers ${ }^{199}$ have examined the social production of space -how social relations are manifested spatially. At its most rudimentary level, the wall in Israel-Palestine 
demarcates space. This affects the shaping of social and economic relations: "The fact of spatial separation is often an important element in the preservation of particular, local,

conditions of production." 200 Spatial separation generates differentiation, and upholds a particular division of labour. While preserving certain conditions of production, the wall also performs economic restructuring. These processes are central to facilitating the ongoing process of uneven development.

\subsubsection{Uneven Development in the era of neoliberalism}

The colonization of Palestine must be understood within the context of capitalism. When the wall was announced in 2002 under the government of Ariel Sharon, it was during a period of neoliberal economic reforms. Deep in recession and amidst cuts to social spending, this new 'security' project would cost the Israeli treasury 3.4 billion dollars. ${ }^{201}$ Much of this money has fallen directly into the pockets of private construction firms and 'defense and security' corporations. Anita Vitullo highlights, "It has been an expensive project but lucrative for private Israeli building and materials contractors, especially for those who have close relations with the Luka government, cultivated since Sharon's earlier days as minister of housing and infrastructure and settlement czar; they are making huge profits."202

This profiteering can also be witnessed in other fencing projects underway in Israel. In 2010, it was announced that Prime Minister Netanyahu had ordered that fencing be constructed along Israel's border with Egypt, as part of an ostensive effort to restrict African migrant workers and refugees and 'terrorists' from entering the country. While Netanyahu affirmed, "This is a strategic decision to secure Israel's Jewish and democratic 
character," 203 the fencing project is reportedly projected to cost 270 million dollars, ${ }^{204}$ and thus delivers extensive revenue to private contractors, such as security firm Yehuda Fences. Haaretz reported in 2011 that 30,000 to 40,000 labour migrants, the majority claiming to be asylum seekers, entered Israel in the preceding five years. ${ }^{205}$ Like the Apartheid Wall, the Israel-Egypt barrier is a political-economic strategy to restrict mobility in an era of social instability, while adhering to a logic of accumulation within neoliberalism.

Neoliberalism, according to Harvey, involves the redistribution, rather than generation, of wealth. ${ }^{206}$ Through allocating mass public funds to private firms for the construction of security walls and fences, we see the state playing an active role in redistributing wealth to the rich. Here, we witness the redistribution of wealth expressing itself spatially through the architecture of the West Bank wall, and elsewhere.

Doreen Massey writes that "spatial form and spatial strategy can be an active element of accumulation." ${ }^{207}$ The wall should be conceived as a spatial strategy, as part of wider political and economic goals. As physical infrastructure, it has an active role to play in shaping the relations of production in Israel-Palestine through preserving segmented labour economies and obstructing economic flows. Thus, the wall's role in spatializing inequality through a process of uneven development becomes evident, amidst an era of neoliberalism. 


\subsection{Uneven Development and the US-Mexico border security wall}

\subsubsection{Spatializing neoliberalism}

While militarization has long typified the US-Mexico borderlands, the erection of the wall, as a further stage in its securitization, corresponds to the enactment of a neoliberal agenda in the US and Mexico, and by extension, an intensification in economic inequality. The practices of neoliberalism are often contradictory, yet consistently accommodate the interests of the transnational ruling class. It is this feature of neoliberalism that gave rise to the infamously exploitative Maquiladora sector in Mexico. The industry was generated through the Mexico-initiated Border Industrialization Program, and ultimately serves the interests of the American capitalist class. The enactment of neoliberal reforms in Mexico, and the Volcker Shock ${ }^{208}$ that drove Mexico to default in $1982-1984,{ }^{209}$ has undoubtedly required greater efforts to pacify resistance to deepening social inequality. As Harvey highlights, neoliberalism, in practice, has meant that borrowers (in this case, Mexico) must finance debt repayment "no matter what the consequences for the livelihood and well-being of the local population." 210

The wall, as a component of the neoliberal regime, has played a fundamental role in conditioning workers to accept heightened exploitation and deteriorating working conditions. As Dunn notes, there is a positive correlation between increased US foreign investment in Mexico during the early 1980s and 1990s, the extraction of wealth from Mexico, and the increasing militarization of the border. ${ }^{211}$ Engaging in repression is necessary to consolidate ruling class power: "The neoliberal state will resort to coercive legislation and policing tactics... to disperse or repress collective forms of opposition to 
corporate power. Forms of surveillance and policing multiply. ${ }^{, 212}$ The regulation of space itself becomes an important dimension of not only regulating and segmenting labour, which Harvey identifies as a component of neoliberalism, but also managing dissent to neoliberalism. Territorial rights, then, become an important dimension of state power. And although there is nothing inherent within the logic of capitalism that demands the preservation of the nation-state, in practice, it has overseen the consolidation of class power. The erection of the border security wall performs each of these functions: affirming the state's terrain of judicial power for the purpose of social control, and segmenting labour when necessary, given capitalism's reliance on exploitable labour reserves. The period of neoliberal reform in Mexico has produced 'risk,' - a liability of opposition - requiring methods of pacification to consolidate conditions of exploitation. We have previously examined how the wall, through increased surveillance and through filtering bodies, has led to a greater regulation of workers. The US has enacted policies that construct regulated and exploitable labour through this filtering, and this has profited elites in the United States. However, the wall also seeks to secure an exploitable labour force for Mexico's industrial sector. In the strategic relocation of industrial enterprises, the Mexican labour economy is differentiated from its Northern counterpart; this is a contradictory feature of capitalism, and a trait uneven development.

In the neoliberal remittance economy, migrants themselves born the costs of these financial transfers, paying often costly fees to financial institutions. According to Hernandez and Bibler Coutin, remittances are thus the ideal neoliberal financial currency, whereby individuals assume the financial risks involved, and value is generated within states without any necessary investments. ${ }^{213}$ While remittances are an important source of 
income for many families and communities, the costs born on migrants, and the profit they generate for Western financial institutions, suggest that they do not contribute meaningfully to a process of geographical equalizing. Remittances, nonetheless, remain a push factor for migration, and participation in temporary foreign worker programs. While capitalists operating in both the United States and Mexico would benefit from a steady supply of surplus labour concentrated in these respective territories, the wall engages in an act of attunement, ensuring that a supply of exploitable labour is present both in the US and Mexico. While US border policies have catered largely to the American elite's demand for inflows of exploitable labour, an unimpeded flow of labour would be detrimental to US elite interests in Mexico, which seek a precarious and casual labour force there. Since 1980, the US-Mexico border has seen 2,340 export processing plants established, 90 percent of which are US-owned. ${ }^{214}$ This speaks to the complex dynamic of labour regulation in the US and Mexico.

Meanwhile, the development of particular immigration policies are also the effect of an intricate political courting performed by US state officials seeking to appease nationally confined business, US-based transnational actors, and to a lesser extent, a segment of the population that perceives migration as a threat. But as we witness clearly under neoliberalism, the state mainly caters to the interests of transnational capital, most starkly illustrated in the passing of the North American Free Trade Agreement (NAFTA) in 1994. It is through an exploration of the spatial dimensions of labour in the era of transnational capital that we will come to understand how the wall is ultimately serving capitalist expansion beyond 'national interest,' while pacifying workers on both sides of the border. 
Immediately following the termination of the Bracero Program, Mexico launched the Border Industrialization Program. The program allowed American manufacturing firms to establish subsidiary factories within Mexico. While workers were being denied freedom of movement into the United States, the Mexican government was developing policies that would further shape the relations of production in its northern borderlands. US capitalists could continue to access Mexican labour as reserve labour in spaces ripe for exploitation.

It was following the 1982-1988 Mexican economic crisis that the maquiladora sector expanded, which now forms the primary industry of the borderland cities. The Salinas administration oversaw an "aggressive implementation of neoliberal economic policies,"215 further constructing an economic environment of deregulation to the appeasement of profit-seeking business. Located in export processing zones (EPZs), maquiladoras are often free form economic controls, including labour regulations, trade tariffs and duties. Manufacturing factories characterized by low wages, workplace harassment, gender exploitation, and low union density, maquiladoras assemble goods for Mexico's northern neighbours, and form one of the "largest industrial workforces in the contemporary global economy."216 While some of the smaller factories are owned by Mexican subcontractors, many of the maquiladoras are owned by transnational corporations, while much of the management is Mexican. ${ }^{217}$

The maquiladoras are an effect of an overall restructuring of the global economy, whereby production processes have been transferred to areas of the world where labour costs are lowest. This "has been instrumental in the renewal of labour control and discipline in both the United States and abroad, and has resulted in higher levels of 
corporate profits as well as class polarization." 218 While the wall has facilitated the movement of documented workers into the United States in conjunction with worker visa programs, it also has a role to play in regulating these flows. The wall keeps contained an exploitable labour economy within Mexico, which is disciplined into accepting the poor working conditions of the maquiladoras partially because the wall regulates access to economic opportunities elsewhere. According to Massey:

The fact of spatial separation is often an important element in the preservation of particular, local, conditions of production -low wages, loyalty to the company and concomitant lack of militancy may be easier for a company to ensure in an isolated area where there is a degree of local spatial monopoly over the labour force. ${ }^{219}$

So while capitalist expansion requires the increased and unregulated flow of capital across space, acquiring new markets for the generation of profit, labour must be regulated -relocated when necessary, contained to a particular location, or both.

Neil Smith describes how 'geographical space' -that which is "manifestly physical" -has a role to play in "the evolution and survival of capitalism." His description of geographical space is useful in contemplating how the wall, as physical architecture, engages with space to solidify capitalist economic relations:

It is the totality of spatial relations organized to a greater or lesser extent into identifiable patterns, which are themselves the expression of the structure and development of the mode of production. As such, geographical space is more than simply the sum of separate relations that comprise its parts. Thus the division of the world into underdeveloped and developed worlds, however inexact, can only be comprehended in terms of geographical space as a whole. It involves the expression of the relation between capital and labour. ${ }^{220}$

The physical wall, which arose amidst the liberalization of trade between the US and Mexico, as a subsequent phase in the development of capitalism, has a clear role in the production of geographical space. Smith's definition of geographical space emphasizes the significance of spatial division as an expression of capitalist social relations. However 
the wall is not merely an effect of capitalism as much as it is an instrument -fortifying existing spatial divisions that benefit capital accumulation and producing the conditions that enable exploitable labour. It is a state-sanctioned spatial control that maintains a significant wage disparity between the two economies. As Robinson notes, "A free flow of labour would exert an equalizing influence on wages across borders whereas state controls help reduce such differentials. Eliminating the wage differential between regions would cancel the advantages that capital accrues from disposing of labour pools worldwide."221 This, in essence, explains the significance of national borders, the citizenship regime, and other border controls such as the wall. And this, ultimately, has led to a global stratification of labour subject to pacification in the workplace and elsewhere as a result of regulated access to economic opportunities.

\subsubsection{The wall and the security-industrial complex}

Despite its own theoretical assertions of favouring laissez-faire economics, neoliberalism in practice has equated to massive financial support for the rich. Under the guise of 'stimulating the economy,' this reallocation of wealth to the business class has taken various forms: bank bailouts; no-strings-attached corporate subsidies; and massive state contracts awarded across industries, but particularly concentrated within the security and defense industry. The wall is both politically and economically motivated. Fulfilling the political will of policing citizens and non-citizens, the wall is also manifestly an effect of exorbitant security and defense spending, providing the visual optics necessary to appease a public appetite for machismo guised as 'protection.' These grotesque investments in militarism follow the neoliberal framework of consolidating class power. 
While we have established that the militarization of the border began long before the widespread neoliberal economic reforms in Mexico, deep investments in border security infrastructure took off during this time period; from the late 1970s onwards, a highprofile and high-intensity campaign to configure a purported sealing of the US-Mexico border took place. ${ }^{222}$ This initiative has cost the public billions of dollars. ${ }^{223}$ The budget for US border control has increased astronomically since the mid 1980s, growing from 281 billion in 1985 to 1660 billion in $2002 .{ }^{224}$

While Coleman and Ackleson, echoing many others, suggest that "these efforts constitute a tension between geopolitical security measures and a 'debording' geoeconomic strategy that seeks market neoliberalization,"225 this assertion obscures the ways in which securitization has led to the growth of trade and commerce. Foucault writes, "Basically, the fundamental question is economics and the economic relation between the cost of repression and the cost of delinquency." While repression has massive public costs, it has major payoffs for the private sector. The border's security infrastructure in fact facilitates economic flows, with public resources fluidly travelling into the pockets of defense and security firms as well as the financial sector. Thus, applications of the term 'neoliberalism' should move beyond narrowly-defined ideological parameters and instead take into account its practical application -in particular, the nature of wealth distribution under neoliberalism. If we are to understand economic globalization as the intensification of capitalist relations of production, then these policies that privilege the private sector are most certainly complimentary to the process of neoliberalism. 
The wall and the border's high-tech security apparatus is an exploding market for private security and technology firms. This year, Phoenix, Arizona hosted the $6^{\text {th }}$ annual Border Security Expo, featuring over 60 speakers, including a keynote address from Arizona Governor Jan Brewer. Hundreds of salespeople representing hundreds of firms attended, including General Dynamics, FLIR Thermal Imaging, Raytheon, Texas Homeland Security Alliance, and StrongWatch, seeking to promote their products and gather information on trends within the border security market. Perhaps the most extravagant private contract to date is the one awarded to Boeing for a projecting beginning in 2006 aimed at constructing an invisible fence along the US-Mexico border, equipped with high-tech cameras and radar systems. The project was part of the 4.4 billion Secure Border Initiative. In 2010, after more than 1 billion had been invested in the project, and after only 53 miles of "unreliable coverage along the nearly 2,000-mile border," the project was not renewed, with the Department of Homeland Security citing inefficiencies, technological challenges, and project expectations not being attained. ${ }^{226}$ Thus, valorizing the wall is a means of transferring public funds to the private sector. This furthers a process of uneven development through redistributing resources to the rich, in an era of neoliberalism in which ruling class power is consolidated.

\subsection{Conclusion}

In an era of globalization supposedly characterized by unimpeded flows, we witness capitalism plagued with apparent contradictions. Capital is becoming increasingly concentrated while permeating new places, and there lies an inherent tendency to differentiate and equalize space. Border security walls exemplify how spatial strategy is 
utilized to situate people within the relations of production. Economic inequalities are exacerbated by shameless state investments in the private sector, and coming full circle, security infrastructure has pacifying effects, mediating rejections to inequality and its particular spatial configurations. Migrants are pursuing new localities. Whether Mexican migrants hoping to access better jobs or Sudanese refugees seeking asylum in Israel, states are executing walling projects to spatially contain certain forms of social instability.

The walls have fortified broader efforts to segment labour economies and secure exploitable labour forces. While the movement of labour is facilitated when necessary, as witnessed in the development of temporary foreign worker programs, maintaining spatial divisions can facilitate capital accumulation through regulating and containing supplies of labour; constructing wage differentials -as a technique in suppressing wages - deliver advantageous climates for capital accumulation.

In Palestine, we witness how historically, Palestinian workers have been designated as second class citizens, and this has articulated itself in spatial configurations of isolation and enclosure. The wall is the architecture of this initiative: it is part of a spatial strategy to achieve particular political-economic gains intimately related to a project of colonialism to which territory -its occupation and theft-remains central.

In Mexico, the Maquiladora sector represents the enactment of neoliberal policies, whereby 'freedom to expand' is delegated only to capital and its possessors. It becomes evident that neoliberal development is uneven development, and geography remains central to just how effective neoliberal measures outplay themselves. Border security walls, as particularly racy security technologies for governments, represent emerging 
avenues for public wealth to be transferred to private actors, and this will have definitive outcomes in the exacerbation of inequality under neoliberalism. Thus, Border security walls facilitate uneven development and further spatialize inequalities rooted in the historic development of social relations. 


\section{Chapter: Repressing Resistance through Ideological and Coercive Mechanisms}

\subsection{Introduction}

The United States, as a settler state, is founded on the domination of other peoples. The state itself facilitated colonial expansion through both coercive and ideological measures. It provided moral leadership to its citizens during this process. Gramsci sees a general transition to the war of position from the war of maneuver with the colonial expansion of Europe. Hegemony becomes grounded in the institutions of civil society, including schools and religious and cultural organizations. The state becomes educative and formative, extending beyond its coercive and instrumental functions. ${ }^{227}$ The masses must adopt a particular ethical code that subscribes to the needs of capital. In the case of colonialism, state institutions played a fundamental role, alongside the church, in shaping moral-ideological discourses pertinent to the domination of Indigenous peoples. These discourses were rooted in notions of white superiority.

Race was again a fundamental tool in legitimizing the appropriation of land from Mexicans throughout the $19^{\text {th }}$ century. Racial constructions of Mexicans and other foreign workers that are today employed in the United States are rooted in a long history of colonial relations and long-held ideological convictions of white superiority. Racism, as an ideological weapon and an economic tool, is engrained in the fabric of the nationstate. Again appealing to Gramsci's theory of hegemony, we are able to dissect how racism interplays with nationalist discourses in order to generate consent for harmful immigration laws and a violent security regime. Exuberant pubic spending for the USMexico wall is ultimately legitimized through racist state doctrine that defines a national 
community in accordance with principles of inclusion and exclusion. Mexicans, including those whose families have resided on what is now US land long before Anglo settlers, are constructed as outsiders for the purpose of upholding a geopolitical order necessary for accumulation.

Bogard's theory of 'smoothing machines' offers an interesting lens with which to view border security walls, particularly as objects in processes of assimilation. Assimilation is one of many strategies to generate a cohesive social order, and in the United States, it's been carried out with racist overtones. In this chapter, I examine how the wall engages with assimilation to develop a 'social assemblage' compatible with the capitalist mode of production.

In the case of Palestine, the wall manifests complex dynamics of social struggle that are outplayed spatially as well as ideologically. In this section, I discuss how prosecurity discourse has sought to rationalize the border walls. The logic of security purports that self-preservation is deeply connected to 'preserving the nation.' The United States and Israel have appealed to nationalism to garner support for repressive mechanisms within the security apparatus. In this sense, state-building remains a crucial component of projects of security.

The enforcement of capitalist colonialism in Palestine has been a violent process. This violence has taken the form of war, mass displacement, the bulldozing of homes and fields, and the ongoing militarization of Palestinian spaces. These overt forms of violence have been accompanied by continued economic violence: deliberate, structural efforts designed to marginalize the Palestinian economy and its workers for the purpose of 
'superexploitation.' Inevitably, resistance has formed in response to the violence of capitalist colonialism and apartheid.

The Second Intifada marked escalated hostilities between the Israeli Defense Forces, Palestinian combatants, and civilians. It catalyzed on September 29, 2000, when riots broke out in and around Jerusalem, which were suppressed by Israeli police

ammunition. The wall, which was erected following the Second Intifada, ${ }^{228}$ marks a reactionary effort to curb social unrest, and keep Palestinians contained to the West Bank and Gaza. However, fencing initiatives emerged prior to September's escalating hostilities, and the political developments that gave rise to the erection of the West Bank wall, particularly the Oslo negotiations, need to be considered.

I explore the writings of Gramsci on hegemony to examine just how coercive and ideological mechanisms of control interact within projects of pacification. I look at internal policing measures in Palestine as part of a pacification project, and I discuss how a criminal construct of the 'other,' reified by the wall, shapes these efforts. I establish that the reproduction of hegemony, and engagement in ideological and coercive mechanisms of repression, characterize a major process of border security walls.

\subsection{Coercion, consent, and the Apartheid Wall}

It was in the mid 1990s that the concept of a separation barrier arose. In 1995, Yitzhak Rabin pursued the construction of a security fence along the West Bank Green Line. He commissioned the then energy minister Moshe Shahal to oversee its design. In 1996, Shimon Peres facilitated the construction of a 2-kilometre-wide, militarized, and highly- 
secured buffer zone along the line, consisting of fences, soldiers, and electronic surveillance. Prime Minister Binyamin Netanyahu discarded the project. ${ }^{229}$

These plans need to be understood within the context of Oslo: the establishment of the PA also brought a greater securitization of Palestinian land. As a structure of governance, The PA has sought to police and discipline Palestinians. While power functions to repress, Foucault highlights that it also should be conceived as "a productive network that runs through the whole social body."230 Israel helped to facilitate the creation of the Palestinian Authority. Often out of economic necessity, Palestinians participate in Palestine's security industry and are a component of this productive network. Hence, "For the Palestinians, schooled in the imposed realities of the settlements, the closure regime and 'autonomy,' the wall was less the abandonment of Oslo than its logical, if terrifying, outcome."231

While there had been meager attempts prior to 2000 to construct some form of separation barrier, it wasn't until the Second Intifada that the wall finally came to fruition. While the wall performs many functions, its role in repressing resistance becomes the most palpable when historically contextualized. Immediately following the outbreak of the Second Intifada, Israeli Prime Minister Ehud Barak authorized the building of a barrier in the north of the West Bank. ${ }^{232}$ In 2001 , "under a domestic clamour to end suicide bombings," 233 Ariel Sharon sought to devise a strategy that would keep Palestinians out of Israel. In July 2001, Israel's cabinet endorsed the wall, and the plan materialized.

Supporters of the Apartheid Wall defend it on the basis of security. In the post911 world, 'terrorism' has been sensationalized and state violence has been normalized 
under the guise of 'anti-terrorism.' The defense of 'security,' particularly 'national security,' has infiltrated public discourse and legitimized public policies that violate human rights and constitutional protections. While Israel has been in a 'state of emergency' since 1948, it has nonetheless gained politically from dominant discourses of the post-911 era. While martial law has given Israel the authority to circumvent many of its own laws, the ongoing exacerbation of public panic around security concerns have valorized the wall and discounted its oppressive effects.

The wall is a spatial manifestation of social struggle. In its physicality it is an instrument in the proletarianization of Palestinians and the colonization of historic Palestine. It is an act of aggression against Palestinians -it is a reaction to their resistance movement. It reflects materially and symbolically current power relations between peoples and classes. Social struggle is played out on the terrain of the spatial; social relations are shaped within a space, and space is an instrument to shape them. According to Massey, "what is at issue is a geography of power relations in which spatial form is an important element in the constitution of power itself."234

Yet the battle for power does not strictly occur in the spatial domain; it is also fought out on the terrain of ideological production. While coercion is often exercised over the body through physical means, the generation of consent occurs in the realm of the social through appealing to particular political tools, such as nationalism, racism, misinformation, and fear. The prevailing discourse on security appeals to ideas, not material reality, to generate the consent of the masses. But this must be understood as part of a wider system of dominance that relies also on violence. As Gramsci highlights, "Force can be employed against enemies, but not against a part of one's own side which 
one wishes rapidly to assimilate, and whose 'good will' and enthusiasm one needs."235 Hegemonic rule is characterized by this "dual perspective," colourfully described by Gramsci as "Machiavelli's Centaur -half-animal and half-human. They are the levels of force and of consent, authority and hegemony, violence and civilization...of agitation and of propaganda, of tactics and of strategy, etc."236 So while the bourgeois logic of 'security' reproduces structures of dominance, the wall also seeks to pacify -to repress resistance to Israel's colonial agenda. Meanwhile, the root cause of the Second Intifadathe colonization of Palestine -is erased from public memory.

Although arguably all empires and systems of rule have resorted to strategies of repression, neoliberal institutions seek to normalize repressive tendencies through nationalist discourse. Nationalism, which plays on the egoism of personal identity, attempts to magnify the integrity of a homogenous national culture as a means to build uncritical unity around the system of governance perceivably stemming from it. The inevitable outcome has been the production of a mode of thought that predicates that an assault on the nation is an assault on the self, and the ways of the state becomes engrained in the cultural fabric of the nation; it is normalized and morally right.

Yiftachel and Yacobi suggest that Israel's conquest of the West Bank and Gaza "strengthened Jewish national identity." ${ }^{, 237}$ It is this sense of nationalism that enables Israel to carry out its goals of state-building, capital accumulation, and the economic control of Palestinians. Branded as the "only democracy in the Middle East," this carefully crafted image has provided a moral stamina to the Israeli occupation, and has effectively generated international support for Israel's position within the conflict. Paradoxically, this imaging has further empowered Israel to pursue anti-democratic 
practices: the violation of human rights, inequality before the law, and illegal military occupation.

As Sari Hanafi highlights, Israel's colonial project is not interested in assimilation. ${ }^{238}$ The wall clearly demonstrates this, which divides Palestinians and Israelis based on their ethno-religious identities, and seeks to render Palestinians invisible. The Oslo Accords, which provided for the establishment of the Palestinian National Authority in the West Bank and the Gaza strip, and the entrance of the PLO into the occupied territories, demonstrate Israel's position against the assimilation of Palestinians into Israel's national political community. This would require recognizing Palestinian social and political rights, which impedes its capacity exploit Palestinians economically.

In order to provoke security concerns among Israelis to justify the wall's atrocities, an ideological program of Palestinian criminalization, reinforced by the wall, must also occur:

\begin{abstract}
While the Israeli authorities insist that the separation barrier is to stop possible attacks by Palestinians entering Israel from the West Bank, much of construction is taking place inside the West Bank - encircling cities and villages, and curtailing movement of Palestinians, separating them from their places of work and from basic services (including education and health). The mission members often heard the word "prison" used to refer to the encircled West Bank cities and portions of territories.
\end{abstract}

The wall emblematizes the walls of a prison, and seeks to punish Palestinians. While the wall works symbolically to reproduce the 'criminal' Palestinian, it also does so materially through separating Palestinians from Israelis, deterring cross-solidarity.

The criminalization of Palestinians simultaneously occurs through a system of internal policing. A massive security industry has developed within the Palestinian territories. The international community has poured conditional aid into the OPTs for the 
development of the security industry. In April 2007, the U.S. Congress approved 59.8 million dollars in security assistance for the Palestinian Authority. ${ }^{240}$ This funding is intended to support a program of internal policing. From 2007-2008, 59,000 people were

employed by the Palestinian Authority Security Forces (PASF). ${ }^{241}$ So while the security industry in Palestine provides jobs, these jobs are part of broader project of policing. Oftentimes through economic coercion, Palestinian workers are placed at the centre of Palestinian policing institutions.

Security and defense discourse has thoroughly penetrated the communications of the State of Israel, obscuring the unequal power relations embedded within the conflict. This narrative has been necessary to continue its declared ongoing 'state of emergency,' and it's been an important component in rationalizing its policy of military conscription. Given Israel's exuberant military budget, Israel is well-positioned to develop infrastructures of repression, however ideological tools will become progressively important amidst an increasingly critical international opinion of the conflict. The wall itself has brought attention to the plight facing Palestinians.

\subsection{Racism, hegemony and the US-Mexico Wall}

Spatial-material infrastructure works in tangent with particular social configurations. In the United States, politicians and business have used racism as a tool in consolidating capitalist economic relations. While the global division of labour is geographically stratified, social divisions, whether race-based, gender-based, communalist, or otherwise, hinder the formation of a united resistance to the current economic order. In the US, racism has been essential to producing consent to the exploitation of migrant workers and 
the security regime that advances this exploitation. While the border security wall is very much an effect of racism, it also reproduces it through serving as a symbol against 'threat' and 'cultural invasion.' In its very aesthetics, it obscures the identities of racialized peoples, and contributes to hegemonic constructions of 'the other.'

According to Hall et al., Gramsci understands the capitalist state as "the instrument for conforming civil society to the economic structure." ${ }^{242}$ States rely on both methods of coercion and the consent of the masses to accomplish this. With the emergence of modern democracy in the West, hegemonic discourses have evolved to present state institutions as legitimate expressions of the popular will. Accordingly, 'democratic' institutions are accountable to the public at large and work to mediate conflicting interests in the name of the public good. The legal apparatus contains a judicial fiction, "that all judges impartially embody and represent 'the Law' as an abstract and impartial force." ${ }^{243}$ These and other distortions are necessary for the state to conceal its activities performed in the interest of capital. Like the legal apparatus, the border security regime is presented as serving the interests of the national community. But in order to provide 'security,' threat must likewise be constructed. Thus, threat is projected onto the Mexican identity. These hegemonic ideas, infused with racism, mobilized militias against Mexican uprisings along the borderline in the $19^{\text {th }}$ century, and today mobilize public consent to militarized border infrastructure. The border security wall, as part of a neocolonial project, reflects and reproduces hegemony. 


\subsubsection{Assimilation as Pacification}

Assimilation is the process of bringing into conformity. It can entail bringing one into conformity with a society's laws, practices, and cultural attitudes, and can encompass the suppression of difference. Assimilation, while not synonymous with the generation of consent, remains part of a process of hegemony when it endorses the adoption of hegemonic ideas, including patriotism and acceptance of the rule of law. Assimilation is thus an ideological process that can suppress resistance to capitalism and the security apparatus.

To study 'smoothing machines' is to explore how social relations, particularly relations of power, become 'smooth. ${ }^{244}$ Thus, Bogard's writing on 'smoothing machines' can assist in the dissection of architectures of pacification. From a Foucauldian perspective, smoothing machines "include architectural strategies that optimize the coordination of multiple bodies, which assign limits to their connection and differentiation." ${ }^{245}$ Participating in a contradictory process of exclusion and assimilation, the security fences prescribe racial codifications onto the migrant, and through these codifications generate difference while simultaneously defining the parameters of a homogenous body politic. Through the wall, "we observe the construction of a "social assemblage,' a plane of consistency composed of the most diverse and jumbled materials - bodies and body parts, bits of information, signs, resources, equipment - that 'operationalizes' according to principles of smoothing." 246 The national community is one such 'social assemblage,' whereby contestations and disruptions to the social order are 'smoothed.' Assimilation is essential to this 'smoothing,' and the wall -through its social, psychological and architectural functions - works as a part of this process. 
Bogard poses the question: "What exactly does it mean to "become smooth?," to which he writes, referencing Canetti, that "power, in its most basic form, is incorporation." ${ }^{247}$ Given that the full exclusion of migrants from the nation is not spatially feasible let alone economically desirable, incorporation into the social order is a political goal. Yet assimilation is fundamentally an oppressive process -it presupposes a degree of cultural superiority that denies respect to the individual. Efforts to assimilate and pacify - immigrants in the United States have had racist underpinnings that, in a seemingly contradictory manner, emphasize difference and construct the migrant as an 'other' in addition to facilitating incorporation.

Marie-Theresa Hernandez examines how American right-wing forces used the Banlieue riots in France ${ }^{248}$ to generate fear of the immigrant other. She argues that "what resulted was a major societal shift that deeply affected America, bringing ethnic and class tensions to the fore, creating fear and ultimately displacing hundreds of thousands of people who had been living in the United States for decades." ${ }^{249}$ Her analysis of American public discourse highlights just how racism can be produced transnationally. It also offers insight into how much of the racism generated in the United States stems, firstly, from fear, and secondly, from a desire to protect white privilege. After the riots, right-wing think tanks released statistics sensationalizing Mexican migration, and political commentators positioned immigrants as very real threats to (white) American culture, promoting both nativism and assimilation.

These racist attitudes have intersected with classism, whereby assimilation is driven by a fear of the economically oppressed. The 'American Dream' remains a lived reality 
only for some, emblematic of the economic inequality that plagues the United States and much of the Western world. As Hernandez argues:

The French riots provoked an already panicked American populace that was still worried about another 9-11 attack. Middle class American citizens saw millions of immigrants settling in their communities and when they heard the news from Paris, they easily envisioned the children of these 12 million workers growing up angry and isolated from the American Dream. ${ }^{250}$

Here, we see Mexican immigrants perceivably posing a threat to the established socioeconomic order. Assimilation, then, does not entail incorporating immigrants into a sphere of economic privilege. To the contrary, assimilation is understood as a tactic of pacification -addressing social discontent not with measures that equalize wealth, but with strategies of discipline and social control. Assimilation, in practice, means adopting so-called American values: patriotism, self-sacrifice, abidance to the law, and an ethic of hard work. When immigrant labour is required to serve business, including the business of war, a strategy of assimilation is employed. A January 2004 speech by President Bush, which proposes the creation of a new temporary foreign workers program, celebrates and promotes assimilation in this light:

Every generation of immigrants has reaffirmed our ability to assimilate newcomers -which is one of the defining strengths of our country... As a Texan, I have known many immigrant families, mainly from Mexico, and I have seen what they add to our country. They bring to America the values of faith in God, love of family, hard work and self reliance -the values that made us a great nation to begin with. We've all seen those values in action, through the service and sacrifice of more than 35,000 foreign-born men and women currently on active duty in the United States military. Second, new immigration laws should serve the economic needs of our country. If an American employer is offering a job that American citizens are not willing to take, we ought to welcome into our country a person who will fill that job... The temporary worker program I am proposing today represents the best tradition of our society, a society that honors the law, and welcomes the newcomer. ${ }^{251}$

When assimilation is not possible or desired, building the security apparatus is necessary, and a culture of racism empowers the government to engage in this and other methods of coercion. In Bush's speech, we witness a pro-assimilation discourse coupled with the promotion of policies of exclusion (or provisional inclusion), regulation, and security: 
This month, we have begun using advanced technology to better record and track aliens who enter our country -and to make sure they leave as scheduled...We have significantly expanded the Border Patrol -with more than a thousand new agents on the borders, and 40 percent greater funding over the last two years. ${ }^{252}$

When assimilation is not effective, exclusion becomes necessary. Privilege is protected through limiting access to national spaces. The fences appeal to popular anxieties surrounding 'unchecked immigration' and the penetration and leveling out of privileged spaces. As a 'smoothing machine,' the fences exclude and simultaneous assimilate, operating ideologically and coercively to pacify resistance to capitalism.

\subsubsection{Racism in the US today}

The wall is, in part, a political response to civil society's call to 'protect' America -a vision also incited by state actors. Officials quite deliberately conflate migrants with drug traffickers and terrorists. The concept of the 'illegal alien' has been thoroughly sensationalized in public policy, and numerous federal and state bills have amalgamated 'security' concerns with immigration issues. For example, the 1996 IIRIRA implemented wide-sweeping reforms that further criminalized undocumented migrants while concurrently legislating increased border fencing. These and similar measures have been hailed by racist anti-migrant politicians and organizations. This follows a long history in the United States of institutionalized exclusion based on race; the Immigration Act of 1924 "reflected the tradition of racial nationalism and defined the US as a "white nation.",253

Today's immigration policies continue this legacy of exclusion, while also pursuing an agenda of criminalization. In 2005, Arizona passed Proposition 200, which 
denies undocumented migrants access to publicly-funded social services and public education. $^{254}$ In 2006 , Georgia passed the Georgia Security and Immigration Compliance Act, enlisting state and local police in the enforcement of federal immigration laws. ${ }^{255}$ In effect, the act mandates escalated policing and surveillance of perceived immigrants. In 2010, exhibiting authoritarian tendencies, Arizona became the first US state to require its populace to carry identity papers. The Support Our Law Enforcement and Safe Neighborhoods Act also gives citizens the legal right to sue agencies that may not be enforcing immigration laws. Furthermore, the act gives police the power to arrest and detain suspected undocumented people without a warrant. ${ }^{256}$

These policies have ideological as well as material affects. Materially, migrants are excluded from social, economic, and political life. On the ideological terrain, political institutions are being used to impose a criminal identity onto the migrant other. And racist discourses that justify these measures, as spewed by political actors and their intellectual "deputies," are injected into the public sphere. In the production of hegemony, civil society reproduces these ideas, in what echoes "the spontaneous consent given by the great masses of the population to the general direction imposed on social life by the dominant fundamental group."257

While there is substantial public opposition to nativist and white supremacist organizations, these groups still have a role to play in the production of culture, and are symptoms of institutionalized racism that has shaped the United States throughout history. These groups have successfully lobbied for anti-immigrant legislation, and enthusiastically support the border security fences, morally identifying with the violence that the infrastructure embodies. While a recent report published by the Southern Poverty 
Law Centre (SPLC) suggested that the nativist extremist movement in the United States is collapsing, this has been attributed to the mainstreaming of their politics, with parties such as the Tea Party taking up anti-immigrant concerns. Many of the movement's demands have been successfully legislated, following a resurgence of white supremacist organizing in the United States since the late 1990s. The movement's more extremist contingent has moderated the image of other racist organizations that may not be openly white supremacist, such as the xenophobic Georgia Coalition for Immigration Reduction, which claims that it does not accommodate "persons who believe their race to be superior to others." ${ }^{258}$ Yet collectively, their political clout has expedited the construction of the wall, with the security fences 'smoothing' over the angst of far-right ideologues.

The Minuteman Project, a neo-fascist paramilitary organization and "modern day Latino-hating version of the Ku Klux Klan"259 has expanded from its roots in the Arizona borderlands to other parts of the country. The movement's growth hit an all-time high in 2010 with 319 groups active throughout the United States, yet this number plummeted to 184 in $2011 .{ }^{260}$ According to SPLC, many of the surviving groups are part of a single large coalition, the Federal Immigration Reform and Enforcement Coalition (FIRE), while the Minuteman Civil Defense Corps and the Minuteman Project have crumbled. ${ }^{261}$ Yet these figures are nonetheless disconcerting in an era where chapters of the Klu Klux Klan are still operational, and openly neo-fascist groups, such as the National Socialist Movement, are legally permitted to stage protests and spew hate speech. These organizations advocate and practice racial violence. Robinson writes, "Some [Minutemen] have even been filmed sporting T-shirts with the emblem 'Kill a Mexican Today?' and other have organized for-profit 'human safaris' in the dessert."262 The wall, 
as an expression of society's powerful and privileged political forces, promotes as well as responds to racism. It is a shield that defends white American culture and privilege, whereby whiteness is consolidated through repressive mechanisms.

\subsubsection{Nationalism and the economic order}

The construction of a national community not only buoys the formation of a homogenous and conforming social body, but also establishes the parameters for uneven development, which are reaffirmed by socially constructed national borders. The concept of the 'nation' conveniently normalizes geographically-based economic stratification, while obscuring internal inequalities. The nation is reproduced through hegemonic geopolitical discourse. According to John Agnew and Stuart Corbridge, 'geopolitical discourse' refers to the deployment of certain representations of space that guide the spatial practices central to a geopolitical order. ${ }^{263}$ Agnew argues that "State-defined space or territoriality has tended to monopolize understandings of economic development." 264 As the unrestricted flow of capital and commercial goods becomes increasingly institutionalized in state policy, adjacent regimes of accumulation are set firmly apart by wage, environmental, and labour regulations. $^{265}$ The reification - and fortification - of national boundaries, validated by the dissemination, consumption, and reproduction of sensationalized and exclusionary nationalist ideas, maintains the current geographical division of labour and fosters the conditions for the assimilation and exploitation of internalized others. Racism is one tool in generating consent for not only uneven development, but a racially-stratified division of labour within the United States, implicitly accepted under the coat of the citizenship regime. 


\subsection{Conclusion}

Officials have frequently cited anti-terrorism and the curbing of migration as motivations for the numerous border walls and fences erected across the world in the past few decades. This rhetoric is usually spewed in tandem, conflating migrants with threats to public security. Politicians rely on racist conceptualizations of so-called outsiders to generate popular consent for these infrastructures, and they appeal to nativist attitudes to garner political support for the expansion of security infrastructure. While violence has in some instances been a tactic of resistance within the Palestinian liberation movement, the wall, as it is presented in the public arena, seeks to frame ongoing violence as unidirectional, obscuring the weight of Israel's economic and military strength. As a state that boasts of being 'the only democracy in the Middle East,' Israel has appealed to common sentiments of Islamophobia in the West to project itself as morally superior, despite the institutionalized racism that streams through its political system, and despite a system of racial segregation that contains many Palestinians to the West Bank and Gaza.

The walls function as repressive apparatuses that engage in exclusions. Their coercive mechanisms are evident, for example, in their disciplinary, surveillance, militaristic and regulatory functions. Furthermore, the walls engage with racism to shape cultural assumptions about migrants, while expressing longstanding racial divides that can be traced to colonialism. Exclusion becomes necessary when integration is undesired.

Given Israel and America's favouring of flexible and disposable labour, the full integration of 'outsiders' is not pursued. Instead, we witness a contradictory process of exclusion and assimilation. The fences inscribe racialized (and class-based) codifications onto those that reside both inside and outside state territory, in order to generate 
difference and simultaneously define the breadth of inclusion one can expect to receive within the body politic.

The construction of the border security walls would not likely be possible without the exercising of hegemony: the state has provided moral-political leadership on the crafted questions of immigration control and border security. This does not presume homogenous viewpoints within governing bodies of the state apparatus, but it does point to the role of political actors in using public discourse to create consensus to its policies and practices that may not be in the public interest. Excessive spending on security infrastructure is one such example. And the state reproduces harmful cultural ideas racism, nativism, and nationalism -to support policies that help solidify the capitalist mode of production. 


\section{Chapter: Walls and Resistance}

\subsection{Introduction}

Identifying the wall as a site of pacification presupposes the existence of agents that challenge the power of the ruling class and the security apparatus. Throughout the world, people are confronting structures of violence and architectures of marginalization. In September 2005, when Spain announced that a new border fence would be placed around the exterior of existing ones, some 700 migrants in Morocco participated in a coordinated action in the cities of Melilla and Ceuta to mount the fences. ${ }^{266}$ The actions took place over four weeks until sufficient Spanish defenses were rallied. In Palestine, regular demonstrations are held in protest of Israeli encroachment onto Palestinian land. The aesthetics of the wall are reclaimed with political graffiti that decries the occupation. And on May 1, 2006, Mexicans shut down the San Diego-Tijuana border crossing, in an action of solidarity with the 1-day American general strike and boycott, in support of immigrant rights in the United States. Countless examples of resistance -at the border and elsewhere -demonstrate that many are not easily pacified. This chapter discusses how resistance movements are emerging in the US, Mexico, and Palestine in the face of repression, emphasizing the importance of collective agency in the struggle against injustice.

\section{2 'To exist is to resist': the Israel-Palestine wall and the dialectics of resistance} Yiftachel and Yacobi argue that the construction of the wall and Israel's small expressions of territorial 'disengagement,' such as the partial settlement withdrawal from Gaza, "constitute attempts to manage the growing contradictions of the state's 
'ethnocratic' regime." ${ }^{\text {,67 }}$ Resistance is an inevitable effect of Israel's actions, which the state has sought to tame through employing different tactics that 'smooth out' the effects of colonialism. As the violence of the regime faces increasing criticism internationally and locally, Israel must foster a perception of legitimacy. Yiftachel and Yacobi see the building of the wall and the withdrawal from Gaza as "intimately linked." 268 One is a tool of coercion and the latter appears to express a method of 'negotiation.' Together they illustrate the "half animal and half-human" tactic of governance, demonstrating the dialectical nature of power.

The wall itself becomes a manifestation of dialectical relations. While it seeks to pacify and homogenize Palestinians - maintaining a cohesive social demographic based on the separation of Israelis and Palestinians-it simultaneously produces a multiplicity of subjectivities each engaging in individual as well as collective expressions of agency. Bogard writes that the 'smoothing machine,' in this case the wall, "is the affectual dynamic of a multiplicity of heterogeneous bodies, which produces subjectivity and the collective subject." ${ }^{\text {,69 }}$ Israel's goal to codify and sort Palestinians from Israelis and keep them contained in its open-air prison will only further budding resistance.

Various authors have identified the wall as both a site of repression and one of resistance. Samer Alatout explains that while the wall has effectively criminalized the movement of Palestinians, it has also shaped these once daily practices into forms of resistance. ${ }^{270}$ Tawil-Souri shares this view, arguing that "movement becomes central in the resistance against the spatial manifestation of Israeli domination."271 While the wall seeks to restrict the movement of Palestinians, successfully passing through it expresses a refusal to be separated and constrained. 
The wall is a clear target of graffiti: political art that not only draws attention to the occupation but also inspires resistance. With tags such as "no to the ghetto," "free Palestine," and "to exist is to resist," the wall's aesthetics are not only that of criminality and intimidation, but also empowerment. Far-reaching images of the concrete slabs and barbed wire have attracted negative attention from the international community, bringing with it awareness to the plight of Palestinians, and in particular, bringing clarity to the conditions of apartheid.

Tawil-Souri conceptualizes checkpoint economies as spaces where merchants provide goods and services to the many people waiting to filter through checkpoints. She establishes that checkpoint economies are, in themselves, a form of resistance for Palestinians because merchants have reappropriated spaces of repression in order to survive economically under military occupation. Checkpoint economies feature merchants that provide goods and services to the many people waiting to filter through checkpoints. One of the most bustling is the Qalandia checkpoint: a choke point in the wall that wraps around the West Bank. While the Israeli system of closures has profoundly contributed to Palestinian economic hardship, Palestinians have found ways to adapt. While the wall and its checkpoints have dramatically disrupted the flow of Palestinians across the border, its concentration of Palestinians into one space has simultaneously produced economic opportunities for merchants and taxi drivers. Palestinians have "renegotiated checkpoints as spaces of social and economic existence." 272 While this form of resistance is limited in its own right - the development of checkpoint economies do not mark a powerful confrontation with Israeli forces, and it prescribes to a code of consumption within the capitalist economic framework. Yet in the 
face of colonialism, checkpoint economies are tools for survival. The continued existence of the Palestinian people is a form of resistance, however humble.

\subsection{Building a movement of resistance at the border and beyond}

As a technique of pacification, the wall is a response to growing opposition to the capitalist regime of accumulation. The militarization of the borderlands began in order to quell uprisings that challenged the violence accompanying capitalism. The security regime today is expanding to control currents of resistance within the population. According to Bogard, 'smoothing machines' operate "neither perfectly nor smoothly."273 They are objects of contestation. Resistance to the wall itself, and the exploitation that accompanies it, continues to bud in a plethora of ways. While the border has been a site of contestation, resistance has also developed within workplaces. Workers are organizing together across borderlines to increase workplace protections. Groups have organized mass actions that challenge racist laws and demand that migrant workers be respected. In spite of the wall, which seeks to divide Mexicans from Americans, meaningful expressions of transnational solidarity are taking place, whereby workers in the United States and Mexico are uniting. The wall expresses these relations of power. While seeking to repress, the fences dialectically stimulate the conditions under which resistance ripens - the steel and wire quite starkly bringing to the fore long-standing societal exclusions. And while the wall intensifies the regulatory mechanisms of the state, it cannot spatially contain local pockets of resistance.

The Border Protection, Anti-terrorism, and Illegal Immigration Control Act (HR4427) was passed by Congress in December, 2005, calling for the construction of 900 miles of fencing along the border. It sought the mass arrest and deportation of 11 
million immigrants. The bill would make undocumented migration a felony and would criminalize those that provided services to undocumented migrants. Immigrants responded with vigour. The country would witness some of the most massive mobilizations in its history.

On March 10, 2006, 500,000 people took the streets in Chicago in opposition to the anti-immigrant agenda. ${ }^{274}$ Fifteen days later, millions marched in dozens of cities across the US, including New York, Atlanta, Washington DC, Phoenix, Dallas, Houston, Tuscon, Denver, and Chicago, in a coordinated National Day of Action for immigrant justice. On April 10, again during wide-scale marches, hundreds of thousands of high school students staged walk outs. ${ }^{275}$ Then, on International Workers' Day, millions of people from over 200 cities participated in a one-day general boycott of businesses, school, and work, in an action that's been termed 'The Great American Boycott.',276 Agribusinesses in the south, almost entirely dependent on immigrant labour, "came to a standstill, leaving supermarket produce shelves empty for the next several days."277 Other industries, including landscaping, construction, caregiving, gaming, and transportation, saw major disruptions.

Yet perhaps the most resoundingly symbolic action was the forced closure of several US-Mexico border crossings, signaling a major act of resistance against the international trade regime. In a heartfelt action of solidarity, Mexicans, some Maquiladora workers, formed a human blockade and shut down the Tijuana-San Diego border crossing. The same occurred at crossings elsewhere. While the border is a site of repression, it is also one of resistance. The proposed fencing measure, as part of a supposed effort to 'seal' the border, was met with unpredicted blockages from those the 
legislation targets. This speaks to the "contradictory dynamic guiding the production of space, ${ }^{, 278}$ whereby the exertion of spatial dominance is met with a loss of spatial control. The actions succeeded in defeating HR4427. While it was passed by Congress, it was never approved by the Senate. Significantly, the actions demonstrated to society the great economic leverage, when properly channeled, of America's large immigrant population. The actions displayed the courage of a vulnerable and targeted group that dissented in spite of potential recourse from authorities. And with unions, churches, and other allies joining the chorus for change, the actions highlighted the strength of solidarity.

In the United States, labour unions have historically scapegoated migrant workers for a myriad of labour issues. While the United Farm Workers achieved several important gains for many racialized agricultural workers, and organized many foreign-born workers, ${ }^{279}$ the union campaigned in favour of restrictive immigration policies. ${ }^{280}$ Yet there have since been crucial developments in the US labour movement that express a more inclusive approach to building working class struggle. Beginning in the late 1980s, several predominate unions began organizing Latino immigrants in low-wage sectors. ${ }^{281}$ And in 2000 , "the AFL-CIO ${ }^{282}$ reversed its longstanding support for immigration restriction and embraced a new policy favoring immigrant rights and a path to legalization for the undocumented.",283

Meaningful resistance will require dispelling the myths surrounding the root causes of unemployment and wage suppression in the United States. As Robinson highlights, a positive correlation between rates of immigration and unemployment rates for US citizens has yet to be established. However, the downward mobility of the worker can more aptly be attributed to declining unionization rates and a neoliberal restructuring 
of the economy that has systemically attacked workers' rights, including collective bargaining rights and the right to strike. ${ }^{284}$ Government policies that construct a 'superexploitable' segment of the labour economy - including guest worker programs that deny workers the right to collective bargaining -pose fundamental challenges to the clout of America's working class. The fight for economic justice, including migrant justice, must entail the use of creative actions that challenge the workings of the capitalist system. The successful 2008 Chicago factory occupation of Republic Windows and Doors - carried out largely by documented and undocumented Latino immigrants alongside many black workers - is one such example, as are ongoing migrant 'freedom rides' and the 2006 immigrant justice mobilizations.

While walls are being put up to divide populations from each other, workers are forming cross-border alliances. In the borderlands, workers are rejecting alienating projections of difference. In Mexico, "Border labour organizing has been an example of the possibility for combining difference and unity in cross-border work, by regarding differences and conflict as part of an open democratic process."285 "Community-based labour support organizations," such as the CJM, Grupo Factor X, and CAFOR, are working to build transnational solidarity campaigns through educational initiatives and consciousness-raising. ${ }^{286}$ Given the decrepit conditions of the maquiladoras, these organizations have been effective at challenging workplace abuses and supporting union building initiatives. For example, the Tijuana women's group, Grupo Factor X, organizes programs and workshops that deal with issues such as workplace harassment, union organizing, and reproductive and workplace health. International labour networks are developing with the expansion of global union federations. And while North American 
unions have a lot of progress to make in developing internal infrastructure and coordinating grassroots actions under the framework of internationalism, local democratic forms of resistance harbor much potential to fight off corporate and state attacks. The fronterizo movements are working to redefine the borderlands -challenging economic violence and confronting the neoliberal regime through local and cross-border cooperation. The fences may be projecting particularly debasing subjectivities onto Mexican migrants, but currents of resistance highlight how identities characterized by agency are developing in spaces that transcend the border and form part of an oppositional culture to Western hegemony, contesting state constructions of the migrant other.

\subsection{Conclusion}

I have provided examples to how walls are not merely sites of repression, but also sites of resistance. Under a regime of colonialism, continued survival on the land -a refusal to be displaced -presents opposition to a spatial strategy of colonialism that seeks to dispossess. Tawil-Souri's exploration of checkpoint economies provides an interesting case of sites of repression being reclaimed for the purpose of economic survival. This contestation, however, is limited in scope, particularly given its confinement to capitalist consumption. Resistance to the security regime should encompass anti-capitalist politics in order to correctly identify and problematize the root causes of repression.

I describe the massive mobilizations that took place following passing of HR4427. These mobilizations exposed some of the injustices inherent in the immigration system, and demonstrated the economic leverage working class people have when 
properly channeled. Transnational solidarity, as expressed in the fronterizo movements form a part of this collective power, and directly confront the divisions that border fences attempt to enforce. 


\section{Chapter: Conclusions}

\subsection{Project Overview}

This thesis identifies and explains the major political-economic processes of contemporary border security walls. I have identified four major theoretical tenants, which I arrived at through adopting a materialist approach to the study of walls. Through identifying how exploitation and inequality are inherent to capitalist social relations, the Marxist tradition problematizes the capitalist economic system. Accordingly, I approached my subject with a concern for how people are materially affected by state policies and practices. This entails identifying how border security walls, in conjunction with broader mechanisms of exploitation, construct the conditions necessary to facilitate capital accumulation. Given that border security walls are spatial-material structures, Marxist economic geography has offered useful theoretical tools to deconstruct how the production of space constructs the conditions necessary for the consolidation of class power. This entails an interrogation of colonial histories and racialization, precisely because colonial violence and racism have, in practice, formed the bedrock of the nation state and lie at the foundation of capitalist economic relations. The ideological underpinnings of racist colonial thought are still present in culture today, and this impacts how border security walls facilitate exploitation. Thus, the Gramscian tradition, which has its foundations in Marxism, offers valuable tools to conceptualizing how culture affects state policies, particularly the legitimization of border security walls. Additionally, the concept of pacification has shaped the development of this thesis. Marxist thought emphasizes the role of struggle in the development of the mode of production, and the significance of violence as a means to enforce particular relations of 
exploitation. Thus, conceptualizing border security walls as techniques of pacification has informed the development of these theoretical principles.

The identification and exploration of these four social processes offer a valuable contribution to studies in border security. Border security walls are being erected worldwide at rapid rates, and theorists across disciplines have struggled to identify the reasons behind this phenomenon. While emphasis has been given to increasing needs for security in light of social strife, these explanations do not suffice. Border security walls must be conceptualized as part of the capitalist project, so that their role in perpetuating inequality can be exposed and challenged. Furthermore, these principles reflect an unearthing of histories of violence. This is necessary in order to expose the impacts of colonialism's ongoing legacy. Connecting border security walls to the colonial project is necessary to challenge current manifestations of economic violence to which border security walls contribute. I have sought to deliver a comprehensive materialist analysis of border security walls, which has led me to identify four social processes that they facilitate:

1) Constructing exploitation and the stratification of labour through regulation

2) Facilitating (neo)colonial practices; continuing a history of accumulation by dispossession, and facilitating the institutionalization of private property

3) Spatializing inequalities through a process of uneven development, as it occurs in an era of neoliberalism

4) (Re)producing hegemony; engaging in ideological and coercive mechanisms to repress resistance and produce consent to capitalism and its security apparatus 
In this thesis, I argue that border security fences employ these processes for the purpose of generating capital and consolidating the power of the ruling class, as part of a historical process of colonialism. I affirm that pacification is central to this. I conclude with a discussion on actions of resistance against repression, marginalization, and exploitation, in order to capture inspirations embedded in these actions, and to deliver an alternative presentation of survivors of economic and state violence. While economic and political elites may have substantial material resources at their disposal, power itself is not unidirectional, and the agency of actors at the grassroots manifests itself in meaningful and significant ways.

\subsection{Summary of Additional Findings}

Mass displacement and migration accompany war, occupation, and underdevelopment. While advancements in technology has removed barriers to accessing information and sharing culture, other manifestations of a supposedly 'borderless world' should be called into question. Border security infrastructure has dramatically increased worldwide along the borders of the Western world. This marks attempts to, firstly, regulate labour, and secondly, manage resistance to ongoing violence under capitalism. The case of Palestine exemplifies how the West is seeking to contain active opposition to colonialism and other associated risks.

Inequalities under capitalism are concentrated spatially -as a method of containment and as a result of the uneven nature of industrial development, which has been affected profoundly by colonialism's targeting of particular resources, geographies, and populations. Thus, physical architecture can maintain spatial divisions and regulate 
access to space. The wall in Palestine performs these primary processes in the interests of Israeli business. Across the West, including Israel and the US, legal structures and military-policing infrastructure have been established to enforce particular economic conditions. In conjunction with Israel's checkpoint system and other features of it military-security apparatus, the wall has coercively sought to fortify an ongoing effort by Israel to further capitalist colonialism, having violent implications for Palestinians across the West Bank. Israel's decision to construct the wall demonstrates the significance of space in economic-political projects. This has been evident throughout the colonial era, whereby territory -the conquering of territory and the establishment of territorial boundaries -lay at the foundations of the modern state.

Thus, when theorizing the social processes of the capitalist wall, its role in dividing populations can more accurately be conceptualized as stratifying populations. To keep Palestinians and Israelis demarcated -the most rudimentary focus of the wall -is to produce (economic) stratification through differentiation, codification, alienation, criminalization, and most significantly, pacification. In the case of Palestine, the economy has been proactively destabilized. This has helped to generate a reserve of 'superexploitable' labour for the Israeli economy.

The wall also marks a clear political strategy rooted in Zionism. But the political sphere cannot be examined in isolation from the economic sphere. Historically, racism has played a central role in the expansion of capitalism and colonialism. Consistently, resistance to repression has been demonized through a racist lens. And in the post-911 world, Islamophobia has been an important tool in justifying atrocities committed largely by white people, whether it be in Afghanistan, Iraq, Palestine, or domestically towards 
our internal 'others.' While resistance is, in part, a spatial strategy, the battle against violence and oppression at home and internationally must also be a counter-hegemonic battle. The 'half-human' element of Machiavelli's centaur -the public face of oppression softened through Zionism, nationalism, racism, sensationalism, and fear-mongering need to be confronted head-on.

US Customs and Border Protection form the largest law enforcement organization in the United States. ${ }^{287}$ Employing a variety of techniques and technologies, surveillance at the border is expanding for the purpose of increasing the coercive mechanisms of the state, in order to respond to risks that arise from the entrenchment of economic inequality. Mass expenditures being poured into private security and defense firms ultimately a program of socialism for the rich -overshadows public need, and blurs the public and private spheres. Here we see an enactment of the neoliberal agenda. While the security industry is sponsored by the state, the US-based manufacturing sector has gained access to an exploitable labour force, remaining largely in tact because the global citizenship regime effectively regulates the movement of workers. The fences fortify these spatializations.

With immense resources being poured into a broad securitization effort, the state is hoping to legitimize hysteria surrounding undocumented immigration in order to perpetuate societal divisions, and regulate inflows for the purpose of social control. The US-Mexico wall serves to remind migrants of the barriers to penetrating the body politic, and the challenges for re-entry should one fail to obediently assimilate. Yet immigrants across the United States are refusing to be invisible, despite the consequences, and are finding creative avenues for opposing exploitation. 
The inflated border security regime is purported by deeply engrained racisms, ultimately rooted in a sweeping desire to protect white privilege and the benefits bestowed on those at the top of the citizenship regime's hierarchy. Racism develops consent for temporary foreign worker programs, the Israeli pass and permit system, and a multi-tiered system of labour characterized by unequal rights. This political manufacturing of a stratified labour economy is supported by a hegemonic narration of the white nation. The wall embodies these relations of power. Yet 'smoothing machines' do not operate flawlessly, nor are they permanent. Eventually, all walls come down.

\subsection{Implications of Research}

Although researchers have investigated the marginalizing impacts of walls -and the economic impacts, to a lesser extent -through particular cases studies, there have been limited attempts to understand the role of walls as part of a larger economic project under capitalism. Although the socio-historical climate of each wall varies from case to case, and although they been erected under diverse political regimes, I suggest that particular economic trends can be established among them due to their placement in the global economic structure. Situating security walls within a larger economic project hence marks a worthwhile theoretical contribution to studies in political economy.

This project has sought to identify the oppressive effects of border security walls and problematize government projects that seek to divide us. I do this within an anticapitalist politic. Conceptualizing the wall as a tool to manage risk highlights the destructive, unpredictable, and uneven nature of capitalism. Identifying the colonialist roots of capitalist security projects highlights the violence embedded in the foundations 
of the capitalist mode of production, and emphasizes the colonialist dimension of security today. Conceiving border security walls in this light directs attention towards the current (neo)colonial projects underway in the occupied Palestinian territories and elsewhere.

Exploring the political-economic processes of walls problematize explanations that emphasize walls as security measures. A critical analysis of walls presents historical facts that are often obscured by the pro-security analysis of border security walls. Understanding walls as techniques of pacification enables important histories to be deconstructed and understood.

I have highlighted how the production of space can be used to exploit people and repress resistance. This point has been identified elsewhere by theorists, from the development of the city (and the removal of cobblestone from city streets, for example) to the active ghettoization of populations. The racial component of this process decisively marks the wall in Palestine as an apartheid wall. Characterizing it as such is useful for garnering political support for sanctions against Israel, in accordance with the International Boycott, Divestment, Sanctions (BDS) movement, modeled after the successful boycott of South African apartheid.

Understanding the wall as a technique of pacification frames it as both a tool and an expression of power. Highlighting the power imbalances in the Israel-Palestine conflict challenges 'solutions' that emphasize dialogue and equal responsibility among Israelis and Palestinians. These 'solutions' conceal the realities of the military occupation, the expansion of illegal settlements, and the discriminatory policies of the Israeli government. 
Throughout this project I have aimed to shed light on the violence inherent to temporary foreign worker programs. These programs do not just exist in the US; Canada and other Western nations have adopted similar models. The relations of dependency constructed between employers and foreign workers have led to conditions that, some theorists argue, approach indentured servitude. These programs must not merely be problematized and reformed; they must be completely overhauled in accordance with the demands of the migrant justice movement.

Finally, the analysis presented highlights the 'divide and conquer' nature of capitalism and its security project. Walls, which divide working class people from working class people, construct racial, national, and cultural antagonisms that dilute class solidarity. This, in effect, contributes to the pacification of workers in order to generate capital and further solidify capitalist economic relations. Re-focusing capitalism as the source of exploitation, and exploring responses of resistance, provides insight into how oppressed peoples can move forward in the struggle for justice. 


\section{References and Notes}

${ }^{1}$ CBC News. "Olympic Security Estimated to Cost 900 Million," February 19, 2009. Accessed: $<$ http://www.cbc.ca/news/canada/british-columbia/story/2009/02/19/bc-olympics-cost-colin-hansen.html>. ${ }^{2}$ Davis, Mike (2005). "The Great Wall of Capital," in Against the Wall, ed. Michael Sorkin. New York: The New Press, p. 89.

3 "What we are interested in is not the place which economic relations occupy in the historical succession of different forms of society. Still less are we interested in the order of their succession 'in the idea' (Proudhon), which is but a hazy conception of the course of history. We are interested in their organic connection within modern bourgeois society." Marx, Karl (2000). "Grundrisse," in Karl Marx: Selected Writings, ed. David McLellan. New York: Oxford University Press, p. 392.

${ }^{4}$ Ibid

${ }^{5}$ Marx, Karl (1994). "Preface to A Contribution to the Critique of Political Economy," in Karl Marx: Selected Writings. Ed. Lawrence H. Simon, Cambridge: Hackett Publishing Company Inc., p. 211. ${ }^{6}$ Smith, Neil (2008). Uneven Development: Nature, capital, and the production of space. Athens: University of Georgia Press, p. 3.

${ }^{7}$ Ibid, p.2.

${ }^{8}$ O Tuathail, Gearoid, Simon Dalby and Paul Routledge (1997). The Geopolitics Reader. New York: Routledge, p.3.

9 Dalby Simon, (1991). "Critical geopolitics: discourse, difference, and dissent," Environment and Planning D: Society and Space, 9(3), p. 261.

${ }^{10}$ O Tuathail, Gearoid, Simon Dalby and Paul Routledge (1997). The Geopolitics Reader. New York: Routledge, p.3.

11 Ibid

${ }^{12}$ Rigakos, George S. (2011). "To extend the scope of productive labour': Pacificationas police project," in Anti-Security, ed. Mark Neocleous and George S. Rigakos. Ottawa: Red Quill Books Ltd, p. 58.

${ }_{13}$ Miles, Robert and Malcolm Brown (2003). Racism: Second Edition. London: Routledge, p. 17.

${ }^{14}$ Ibid, p. 9.

${ }^{15}$ Ibid, p. 8.

${ }^{16}$ Ibid, p. 9.

${ }^{17}$ Ibid, p. 10.

${ }^{18}$ Section 2(a) states, "Every oleh under the Law of Return, 5710-1950, shall become an Israel national." An oleh is translated as, "respectively a Jew immigrating, and the immigration of a Jew, into the Land of Israel." Accessed: <http://www.israellawresourcecenter.org/israellaws/fulltext/nationalitylaw.htm>.

${ }^{19}$ Miles, Robert and Malcolm Brown (2003). Racism: Second Edition. London: Routledge, p. 68.

20 Ibid

${ }^{21}$ Ibid, p. 67.

${ }^{22}$ Mykkanen, Juri (1994). "To methodize and regulate them: Petty's governmental science of statistics," History of the Human Sciences, 7(3), p. 75.

${ }^{23}$ Ibid

${ }^{24}$ Petty, Sir William. "The Petty Papers," In A General Police System: Political Economy and Security in the Age of Enlightenment. Ed. Rigakos, G.S., McMullan, J.L., Johnson, J., and Ozcan G. Ottawa: Red Quill Books Ltd, 2009, p. 42.

25 Ibid

${ }^{26}$ Rigakos, George (2005). "Beyond Public-Private: Towards a New Typology in Policing." In Re-imaging Policing in Canada. Ed. Dennis Cooley. Toronto: University of Toronto Press Incorporated, p. 284.

${ }^{27}$ Foucault, Michel (2007). Security, Territory, Population. New York: Palgrave Macmillan, p. 69.

${ }^{28}$ Petty, Sir William. "The Petty Papers," In A General Police System: Political Economy and Security in the Age of Enlightenment. Ed. Rigakos, G.S., McMullan, J.L., Johnson, J., and Ozcan G. Ottawa: Red Quill Books Ltd, 2009, p. 44. 
${ }^{29}$ Brown, Wendy (2010). Walled States, Waning Sovereignty, New York: Zone Books, p. 22.

${ }^{30}$ Rigakos, George (2011). "“To extend the scope of productive labour': pacification as a police project," in Anti-Security, ed. Neocleous, M. and Rigakos, G.S., Ottawa: Red Quill Books Ltd, p. 64.

${ }^{31}$ Gramsci, Antonio (1971). Selections from the Prison Notebooks, ed. Quintin, H. and Nowell Smith, G. New York: International Publishers, p. 12.

${ }^{32} \mathrm{Ibid}$

${ }^{33}$ Hall, Stuart (1986). "Gramsci's Relevance for the Study of Race and Ethnicity," Journal of Communication Inquiry, 10, pp. 5-27.

${ }^{34}$ Neocleous, Mark (2011). "Security as Pacification," in Anti-Security, ed. Neocleous, M. and Rigakos, G.S. Ottawa: Red Quill Books Ltd, p. 24.

${ }^{35}$ Rose, William (2002). "Crimes of Color: Risk, Profiling, and the Contemporary Racialization of Social Control," Journal of Politics, Culture and Society, 16(2), p. 199.

${ }^{36}$ Miles, Robert and Malcolm Brown (2003). Racism: Second Edition. London: Routledge, p. 144.

${ }^{37}$ Neocleous, Mark (2010). "Security as Pacification," in Anti-Security, ed. Neocleous, M. and Rigakos, G.S., Ottawa: Red Quill Books Ltd, p. 39.

${ }^{38}$ Foucault, Michel (2007). Security, Territory, Population. New York: Palgrave Macmillan, p. 1.

${ }^{39}$ Ibid, pp. 44-45.

${ }^{40}$ Rigakos, George (2011). "To extend the scope of productive labour': pacification as a police project," in Anti-Security, ed. Neocleous, M. and Rigakos, G.S., Ottawa: Red Quill Books Ltd, p. 41.

${ }^{41}$ Ibid, pp. 40-41.

${ }^{42}$ Foucault, Michel (1979). Discipline and Punish: The Birth of the Prison. New York: Vintage Books, p. 61 .

${ }^{43}$ Ibid, p. 272.

${ }^{44}$ Foucault, Michel (1997). "Society Must be Defended." New York: Picador, p. 254.

${ }^{45}$ Massey, Doreen (1984). Spatial Divisions of Labour: Social structures and the geography of production. London: MacMillan Education Ltd, p. 11.

${ }^{46}$ Smith, Neil (1984). Uneven Development: nature, capital, and the production of space. Oxford: Basil Blackwell Publisher Ltd, p. 90.

${ }^{47}$ Smith, Neil (2008). Uneven Development: nature, capital, and the production of space. Athens: University of Georgia Press, p. 134.

${ }^{48}$ Ibid, p. 133.

${ }^{49}$ Bogard, William (2000). "Smoothing Machines and the Constitution of Society," Cultural Studies, 14(2), p. 269.

${ }^{50}$ Ibid, p. 271.

${ }^{51}$ Marx, Karl and Fredrich Engels (1994). "The Communist Manifesto," in Karl Marx: Selected Writings, ed. Lawrence H. Simon. Cambridge: Hackett Publishing Company Inc., p. 160.

${ }^{52}$ Ibid, pp. 162-163.

${ }^{53}$ Bogard, William (2000). "Smoothing Machines and the Constitution of Society," Cultural Studies, 14(2), p. 272.

${ }^{54}$ Weizman, Eyal (2007). Hallow Land: Israel's Architecture of Occupation. New York: Verso, p. 168.

${ }^{55}$ Miles, Robert and Malcolm Brown (2003). Racism: Second Edition. London: Routledge, p. 144.

${ }^{56}$ Harvey, David. A Brief History of Neoliberalism. New York: Oxford University Press, 2005, p. 19.

${ }^{57}$ Ibid, p. 159.

${ }^{58}$ Garcia, Michael John and Blas Nunez-Neto (2007). "Border Security: The San Diego Fence." Library of Congress Washington DC Congressional Research Service, p. 2. Accessed June 21, 2012:

<http://handle.dtic.mil/100.2/ADA469083>.

${ }^{59}$ Dunn, Timothy and Joseph Nevins (2008). "Barricading the Border," NACLA Report on the Americas, 41(6), n.p.

${ }^{60}$ Ibid

${ }^{61}$ Ibid 
${ }^{62}$ Brunet-Jailly, Emmanuel (2007). Borderlands: Comparing Border Security in North America and Europe, Ottawa: University of Ottawa Press, 198.

${ }^{63}$ Correia, David (2009). "Making destiny manifest: United States territorial expansion and the dispossession of two Mexican property claims in New Mexico, 1824-1899," Journal of Historical Geography, (35)1, p. 87-88.

${ }^{64}$ Foucault, Michel (1980). Power/Knowledge: Selected Interviews and Other Writings 1972-1977. New York: Pantheon Books, p. 130.

${ }^{65}$ Calavita, Kitty (1995). "Mexican Immigration to the USA: the contradictions of border control," in The Cambridge Survey of World Migration, ed. Robin Cohen. Cambridge: Press Syndicate of the University of Cambridge, p. 252.

${ }^{66}$ Alatout, Samer (2009). "Walls as Technologies of Government: The Double Construction of Geographies of Peace and Conflict in Israeli Politics, 2002-Present," Annals of the Association of American Geographers, 99(5): 956.

${ }^{67}$ The Gaza Strip fencing barrier runs along its entire land border, and features many of the same technologies of the West Bank wall.

${ }_{68}^{68}$ Tawil-Souri, Helga (2009). "New Palestinian centers: An ethnography of the "checkpoint economy."” International Journal of Cultural Studies. Vol. 12 (3), p. 219.

${ }^{69}$ United Nations Office for the Coordination of Humanitarian Affairs, occupied Palestinian territory (2010). "West Bank Movement and Access," p. 2. Accessed: http://www.ochaopt.org/documents/ocha_opt_movement_access_2010_06_16_english.pdf.

${ }^{70}$ Tawil-Souri, Helga (2009). "New Palestinian centers: An ethnography of the 'checkpoint economy."” International Journal of Cultural Studies. Vol. 12 (3), p. 222.

${ }^{71}$ United Nations Office for the Coordination of Humanitarian Affairs, occupied Palestinian territory (2010). "West Bank Movement and Access," p. 2. Accessed: http://www.ochaopt.org/documents/ocha_opt_movement_access_2010_06_16_english.pdf.

${ }^{72}$ Tejanos refers to Mexican Texans.

${ }^{73}$ Bornstein, Avram S. (2002) "Borders and the Utility of Violence: State Effects on the 'Superexploitation' of West Bank Palestinians," Critique of Anthropology, 22(2), p. 206.

${ }^{74}$ Ibid

${ }^{75}$ Usher, Graham (2006). "The wall and the dismemberment of Palestine," Race and Class, 47(3), p. 11.

${ }^{76}$ Yiftachel, Oren and Haim Yacobi (2005). "Barriers, Walls and Dialectics: The Shaping of "Creeping Apartheid" in Israel/Palestine," in Against the Wall: Israel's Barrier to Peace, ed. Michael Sorkin. New York: The New Press, p. 142.

${ }^{77}$ Alatout, Samer (2009). "Walls as Technologies of Government: The Double Construction of Geographies of Peace and Conflict in Israeli Politics, 2002-Present," Annals of the Association of American Geographers, 99(5), p. 959.

${ }^{78}$ Rosenhek, Zeev (2003). "The Political Dynamics of a Segmented Labour Market: Palestinian Citizens, Palestinians from the Occupied Territories and Migrant Workers in Israel," Acta Sociologica, 46(3), p. 239.

${ }^{79}$ Usher, Graham (2006). "The wall and the dismemberment of Palestine," Race and Class, 47(3), p. 14.

${ }^{80}$ Bornstein, Avram S. (2002) "Borders and the Utility of Violence: State Effects on the 'Superexploitation' of West Bank Palestinians," Critique of Anthropology, 22(2), p. 208.

${ }^{81}$ Hanafi, Sari (2005). "Spacio-cide and Biopolitics: The Israel Colonial Project from 1947 to the Wall," in Israel/Palestine," in Against the Wall: Israel's Barrier to Peace, ed. Michael Sorkin. New York: The New Press, p. 159.

${ }^{82}$ Hanafi, Sari (2005). "Spacio-cide and Biopolitics: The Israel Colonial Project from 1947 to the Wall," in Israel/Palestine," in Against the Wall: Israel's Barrier to Peace, ed. Michael Sorkin. New York: The New Press, p. 159.

${ }^{83}$ Harvey, David. A Brief History of Neoliberalism. New York: Oxford University Press, 2005, p. 159.

${ }^{84}$ Ibid

${ }^{85}$ Alatout, Samer (2009). "Walls as Technologies of Government: The Double Construction of Geographies of Peace and Conflict in Israeli Politics, 2002-Present," Annals of the Association of American Geographers, 99(5), p. 956.

${ }^{86}$ Ibid 
${ }^{87}$ Yiftachel, Oren and Haim Yacobi (2005). "Barriers, Walls and Dialectics: The Shaping of "Creeping Apartheid" in Israel/Palestine," in Against the Wall: Israel's Barrier to Peace, ed. Michael Sorkin. New York: The New Press, p. 154.

${ }^{88}$ Weizman, Eyal (2007). Hallow Land: Israel's Architecture of Occupation. New York: Verso, p. 168. ${ }^{89}$ Shapiro, Michael, J (1997). "Narrating the Nation, Unwelcoming the Stranger: Anti-Immigration Policy in Contemporary "America." Alternatives, 22(1), p. 16.

${ }^{90}$ Gomez, Laura E. (2007). Manifest Destinies: the making of the Mexican American Race. New York: New York University Press, p 16.

${ }^{91}$ Limerick, Patricia Nelson (1987). The Legacy of Conquest. New York: Norton, p. 27.

${ }^{92}$ Smith, Neil (1984). Uneven Development: Nature, Capital and the Production of Space. Oxford: Basil Blackwell, 77.

${ }_{93}$ Dunn, Timothy J (1996). The Militarization of the U.S.-Mexico Border, 1978-1992: Low-intensity conflict doctrine comes home. Austin: CMAS Books, p. 7.

${ }^{94}$ Griswold del Castillo, Richard. (1990). The Treaty of Guadalupe Hidalgo: A Legacy of Conflict. London: University of Oklahoma Press, p. 62.

${ }^{95}$ While the application of the term varies, Mestiza/o can refer to those of mixed Spanish and Indian descent. Raza can refer to those who are Indigenous to Mexico or espouse Mexican identity.

${ }_{96}^{96}$ Enslaved people during New World slavery also used flight as a mode of resistance to domination.

${ }^{97}$ Article VIII of the Treaty of Guadalupe Hidalgo, as Ratified by the United States and Mexican Governments, 1928: Mexicans now established in territories previously belonging to Mexico, and which remain for the future within the limits of the United States, as defined by the present Treaty, shall by free to continue where they now reside, or to remove at any time to the Mexican Republic, retaining the property which they possess in the said territories... without their being subjected, on this account, to any contribution, tax or charge whatever.

${ }^{98}$ Euro-American settlers, backed by some of the Mexican elite, declared independence in 1836 from the Mexican Republic. Settlers resented the Mexican government's efforts to curtail slavery, as many of them came from the southern United States accompanied by slaves. Mexico abolished slavery in 1829. Texas would later become annexed by the United States.

${ }^{99}$ Anzaldua, Gloria (2007). Borderlands: La Frontera. San Francisco: Aunt Lute Books, pp. 29-30.

${ }^{100}$ Griswold del Castillo, Richard. (1990). The Treaty of Guadalupe Hidalgo: A Legacy of Conflict.

London: University of Oklahoma Press, p. 74.

${ }^{101}$ Dunn, Timothy J (1996). The Militarization of the U.S.-Mexico Border, 1978-1992: low-intensity conflict doctrine comes home. Austin: CMAS Books, p. 8.

${ }^{102}$ The ejido would become enshrined as a constitutional right as a result of the Mexican Revolution (19101920). The North American Free Trade Agreement of 1994 eroded this right.

${ }^{103}$ Hernandez, Sonia (2001). "The Legacy of the Treaty of Guadalupe Hidalgo on Tejanos' Land," Journal of Popular Culture, 35 (2), p. 105.

${ }^{104}$ Dunn, Timothy J (1996). The Militarization of the U.S.-Mexico Border, 1978-1992: low-intensity

conflict doctrine comes home. Austin: CMAS Books, p. 7.

${ }^{105}$ Ibid

${ }^{106}$ The Plan de San Diego was a radical proclamation that called for rebellion against the United States and the creation of an independent republic in the lands confiscated from Mexico through the Treaty of Guadalupe Hidalgo. It called for the killing of every Anglo male over the age of 16.

${ }^{107}$ Johnson, Benjamin (2004). "The Plan de San Diego Uprising and the Making of the Texas-Mexican

Borderlands," in Continental Crossroads: Remapping US-Mexico Borderlands History, eds. Samuel Truett and Elliott Young. London: Duke University Press, p. 274.

${ }^{108}$ Ibid

${ }^{109}$ Dunn, Timothy J (1996). The Militarization of the U.S.-Mexico Border, 1978-1992: low-intensity conflict doctrine comes home. Austin: CMAS Books, p. 9.

${ }_{110}$ Article IX of the Treaty of Guadalupe Hidalgo, as Ratified by the United States and Mexican Governments, 1928, in The Treaty of Guadalupe Hidalgo: A Legacy of Conflict, ed. Richard Griswold del Castillo (1990), London: University of Oklahoma Press, p. 179.

${ }^{111}$ David Kazanjian, 2003; María Josefina Saldaña-Portillo, 2004. 
${ }^{112}$ Saldaña-Portillo, María Josefina (2004). "'Wavering on the Horizon of Social Being': The Treaty of Guadalupe-Hidalg and The Legacy of its Racial Character in Americo Paredes's George Washington Gomez," Radical History Review, (89) Spring, p. 140.

${ }^{113}$ Ibid, p. 152.

${ }^{114}$ Foucault, Michel. (2004). Security, Territory, Population: Lectures at the Collège de France 1977-1978. New York: Palgrave Macmillan, p. 45.

${ }^{115}$ Heyman, J. (1998). "State effects on labour exploitation: the INS and undocumented immigrants at the Mexico-United States border." Critique of Anthropology, 18 (157), pp. 157-158.

${ }^{116}$ Marx, Karl (2000). "Economic and Philosophical Manuscripts," in Karl Marx: Selected Writings, ed. by David McLellan. New York: Oxford University Press, p. 86.

${ }^{117}$ Cohen, Yinon. (2009). "Israel: the demographic and economic dimension of migration," in CARIM Mediterranean Migration Report 2008-2009, ed. Philippe Fargue, Robert Schuman Centre for Advanced Studies, San Domenico di Fiesole, European University Institute, p. 101.

${ }^{118}$ Ibid

${ }^{119}$ Central Bureau of Statistics (2011). Israel in Figures: 2011. State of Israel, p. 17. Accessed: <http://www1.cbs.gov.il/www/publications/isr_in_n1le.pdf>.

${ }^{120}$ Ibid

${ }^{121}$ Sa'di, Ahmad H. (1995). "Incorporation without Integration: Palestinian citizens in Israel's labour market," Sociology, 29 (3), 440.

${ }^{122}$ Ibid, p. 431.

${ }^{123}$ Ibid, p. 444

${ }^{124}$ Exceptions include ultra-orthodox Jews and some persons with disabilities.

${ }^{125}$ Sa'di, Ahmad H. (1995). "Incorporation without Integration: Palestinian citizens in Israel's labour market," Sociology, 29 (3), p. 444.

${ }^{126}$ Entitled, Employment in the Public Service (Appointments)(Amendment-Affirmative Action) Bill 2009

${ }^{127}$ Lis, Jonathan. "Bill giving priority to ex-soldiers ruled unconstitutional: proposed law pits Attorney general vs. Yisrael Beiteinu party." Haaretz. June 17, 2011. Accessed: <http://www.haaretz.com/printedition/news/bill-giving-priority-to-ex-soldiers-ruled-unconstitutional-1.368129>.

${ }^{128}$ It's important to note that other migrant workers in Israel, particularly those from Africa, have faced increasing hostility from the State of Israel. In June, 2012, Haaretz reported that Prime Minister Benjamin Netanyahu has demanded that efforts to deport undocumented migrants from South Sudan, the Ivory Coast, Ghana and Ethiopia be accelerated, and that holding facilities be rapidly constructed to house those unable to return to their home countries. See:

Ravid, Barak. "Netanyahu orders swift deportation of 25,000 illegal African migrants," in Haaretz. June 4, 2012. Accessed: <http://www.haaretz.com/news/diplomacy-defense/netanyahu-orders-swift-deportationof-25-000-illegal-african-migrants-1.434190>.

${ }^{129}$ Farsakh, Lelia (2005). Palestinian Labour Migration to Israel: Labour, land, and occupation. New York: Routledge, p. 106.

${ }^{130}$ Cohen, Yinon. (2009). "Israel: the demographic and economic dimension of migration," in CARIM Mediterranean Migration Report 2008-2009, ed. Philippe Fargue, Robert Schuman Centre for Advanced Studies, San Domenico di Fiesole, European University Institute, pp. 101-102.

${ }^{131}$ Beginning in the late 1990 s, West Bank Palestinians needed an Israeli employer to submit a request to the labour office in order to get a work permit for Israel, which further required the approval of the IDF.

See: Bornstein, Avram S. (2002) "Borders and the Utility of Violence: State Effects on the 'Superexploitation' of West Bank Palestinians," Critique of Anthropology, 22(2), p. 208-209.

${ }^{132}$ Cohen, Yinon. (2009). "Israel: the demographic and economic dimension of migration," in CARIM Mediterranean Migration Report 2008-2009, ed. Philippe Fargue, Robert Schuman Centre for Advanced Studies, San Domenico di Fiesole, European University Institute, p. 101.

${ }^{133}$ Bornstein, Avram S. (2002) "Borders and the Utility of Violence: State Effects on the 'Superexploitation' of West Bank Palestinians," Critique of Anthropology, 22(2), p. 203.

${ }^{134}$ Vitullo, Anita (2005). "The Long Economic Shadow of the Wall," in Against the Wall: Israel's Barrier to Peace, ed. Michael Sorkin. New York: The New Press, p. 106. 
${ }^{135}$ Ibid

${ }^{136}$ Ibid, p. 104.

${ }^{137}$ Alatout, Samer (2009). "Walls as Technologies of Government: The Double Construction of Geographies of Peace and Conflict in Israeli Politics, 2002-Present," Annals of the Association of American Geographers, 99(5), p. 956.

${ }^{138}$ Vitullo, Anita (2005). "The Long Economic Shadow of the Wall," in Against the Wall: Israel's Barrier to Peace, ed. Michael Sorkin. New York: The New Press, p. 103.

${ }^{139}$ Bormstein, Avram S. (2002) "Borders and the Utility of Violence: State Effects on the 'Superexploitation' of West Bank Palestinians," Critique of Anthropology, 22(2), p. 203.

140 Alatout, Samer (2009). "Walls as Technologies of Government: The Double Construction of Geographies of Peace and Conflict in Israeli Politics, 2002-Present," Annals of the Association of American Geographers, 99(5), p. 962.

${ }^{141}$ Ibid

${ }^{142}$ Ibid

${ }^{143}$ Bornstein, Avram S. (2002) "Borders and the Utility of Violence: State Effects on the 'Superexploitation' of West Bank Palestinians," Critique of Anthropology, 22(2), p. 203.

144 The PA was formed in 1994 following negotiations between Israel and the Palestine Liberation Organization (PLO), which culminated in the signing of the Oslo Accords. It combines the West Bank and Gaza under a single political unit (As a result of the January 2006 elections, the West Bank is currently represented by the political party Fatah, and Gaza by Hamas. Hamas holds the majority of seats in the Palestinian parliament, the Palestinian Legislative Council). It has, in theory, civil and military control of Area A, and civil control of Area B. Israel governs Palestinians living in Area C, which includes the majority of the West Bank.

In practice, the PA has limited autonomy, particularly given the nature of the Israeli occupation. It primarily performs administrative responsibilities, such as the provisioning of social services, and the hiring of police and teachers.

${ }^{145}$ Calavita, Kitty (1995). "Mexican Immigration to the USA: the contradictions of border control," in The Cambridge Survey of World Migration, ed. Robin Cohen. Cambridge: Press Syndicate of the University of Cambridge, p. 238.

${ }^{146}$ Dunn, Timothy J (1996). The Militarization of the U.S.-Mexico Border, 1978-1992: low-intensity conflict doctrine comes home. Austin: CMAS Books, p. 1.

${ }_{147}$ Ibid, p. 11.

${ }^{148}$ Ibid, p. 12.

${ }^{149}$ Taylor, Edward J (2010). "Agricultural Labour and Migration Policy," The Annual Review of Resource Economics, issue 2, p. 379.

${ }^{150}$ lbid, p. 13.

${ }^{151}$ Taylor, Edward J (2010). "Agricultural Labour and Migration Policy." The Annual Review of Resource Economics, issue 2, p. 380.

${ }^{152}$ Ibid

${ }^{153}$ Dunn, Timothy J (1996). The Militarization of the U.S.-Mexico Border, 1978-1992: low-intensity conflict doctrine comes home. Austin: CMAS Books, p. 14.

${ }^{154}$ Ibid

${ }_{156}^{155}$ Ibid, p. 12.

${ }^{156}$ Heyman, Josiah McC (1998). "State Effects on Labour Exploitation: The INS and undocumented immigrants at the Mexico-United States border," Critique of Anthropology, 18(2), p. 160.

${ }^{157}$ Dunn, Timothy J (1996). The Militarization of the U.S.-Mexico Border, 1978-1992: low-intensity conflict doctrine comes home. Austin: CMAS Books, p. 16.

${ }^{158}$ Foucault, Michel (1980). Power/Knowledge: Selected Interviews and Other Writings 1972-1977. New York: Pantheon Books, p. 55.

${ }^{159}$ Trigueros-Legarreta, Paz (2012). "The Vulnerability of Mexican Temporary Foreign Workers in the United States with H-2 Visas," in Migration and Remittances From Mexico: Trends, Impacts, and New Challenges, ed. Alfredo Cuechecha and Carla Pederzini. Plymouth: Lexington Books, p. 143. 
${ }^{160}$ Marchand, Marianne H (2008). "The Violence of Development and the Migration/Insecurities Nexus: labour migration in a North American context," Third World Quarterly, 29(7), p. 1377.

${ }^{161}$ Calavita, Kitty (1995). "Mexican Immigration to the USA: the contradictions of border control," in The Cambridge Survey of World Migration, ed. Robin Cohen. Cambridge: Press Syndicate of the University of Cambridge, p. 238.

${ }^{162}$ Trigueros-Legarreta, Paz (2012). "The Vulnerability of Mexican Temporary Foreign Workers in the United States with H-2 Visas," in Migration and Remittances From Mexico: Trends, Impacts, and New Challenges, ed. Alfredo Cuechecha and Carla Pederzini. Plymouth: Lexington Books, p. 145.

${ }^{163}$ Public Papers of the Presidents of the United States: George W. Bush (2006, Book I). United States Government Printing Office. Accessed June 10, 2012: < http://www.gpo.gov/fdsys/pkg/PPP-2006book1/html/PPP-2006-book1-doc-pg559.htm>.

${ }^{164}$ Ibid

${ }^{165}$ Calavita, Kitty (1995). "Mexican Immigration to the USA: the contradictions of border control," in The Cambridge Survey of World Migration, ed. Robin Cohen. Cambridge: Press Syndicate of the University of Cambridge, p. 238.

${ }^{166}$ Consulate General of the United States. "H2 Visas: temporary laborers." The U.S. Department of State. Accessed May 29, 2012: <http://monterrey.usconsulate.gov/h2_visa.html>.

${ }^{167}$ Trigueros-Legarreta, $\mathrm{Paz}$ (2012). "The Vulnerability of Mexican Temporary Foreign Workers in the United States with H-2 Visas," in Migration and Remittances From Mexico: Trends, Impacts, and New Challenges, ed. Alfredo Cuechecha and Carla Pederzini. Plymouth: Lexington Books, p. 151.

${ }^{168}$ Ibid

${ }^{169}$ Ibid, pp. 152-153.

${ }^{170}$ Ibid, p. 151.

${ }^{171}$ Ibid, p. 154.

${ }^{172}$ Ibid, p. 155.

${ }^{173}$ Goldring, Luin; Berinstein, Carolina; and Bernhard, Judith (2007). "Institutionalizing Precarious Immigration Status in Canada," Early Childhood Education Publications and Research. Paper 4, p. 6. Accessed: <http://digitalcommons.ryerson.ca/ece/4>.

${ }^{174}$ Ibid

${ }^{175}$ Heyman, Josiah McC (1998). "State Effects on Labour Exploitation: The INS and undocumented immigrants at the Mexico-United States border," Critique of Anthropology, 18(2), p. 158.

${ }^{176}$ Akleson, Jason (2005). "Constructing security on the U.S.-Mexico Border," Political Geography, 24 (2), p. 172 .

${ }^{77}$ Heyman, Josiah McC (1998). "State Effects on Labour Exploitation: The INS and undocumented immigrants at the Mexico-United States border," Critique of Anthropology, 18(2), p. 165.

${ }^{178}$ Marchand, Marianne H (2008). "The Violence of Development and the Migration/Insecurities Nexus: labour migration in a North American context," Third World Quarterly, 29(7), p. 1385-1386.

${ }^{179}$ Coutin, Susan Bibler (2010). "Confined within: National territories as zones of confinement," Political Geography, 29(4), p. 201.

${ }^{180}$ Neocleous, Mark (2011). "Security as Pacification," in Anti-Security, Ed. Mark Neocleous and George S. Rigakos. Ottawa: Red Quill Books Ltd, p. 42.

${ }^{181}$ Gardner II, Trevor and Aarti Kohli (2009). "The CAP Effect: Racial Profiling in the ICE Criminal Alien Program," The Chief Justice Earl Warren Institute on Race, Ethnicity and Diversity, University of

California Berkley Law School, p. 3. Accessed:

<http://www.law.berkeley.edu/files/policybrief_irving_0909_v9.pdfs.

${ }^{182}$ Ibid

${ }^{183}$ Foucault, Michel. (2004). Security, Territory, Population: Lectures at the Collège de France 1977-1978. New York: Palgrave Macmillan, pp. 44-45.

${ }^{184}$ Heyman, Josiah McC (1998). "State Effects on Labour Exploitation: The INS and undocumented immigrants at the Mexico-United States border," Critique of Anthropology, 18(2), p. 161.

${ }^{185}$ Ibid 
186،'Snapshot: A summary of CBP facts and figures." US Customs and Border Protection, February 2012. Accessed May 28, 2012:

<http://www.cbp.gov/linkhandler/cgov/about/accomplish/cbp_snapshot.ct//snapshot.pdf>.

${ }^{187}$ Heyman, Josiah McC (1998). "State Effects on Labour Exploitation: The INS and undocumented immigrants at the Mexico-United States border," Critique of Anthropology, 18(2), p. 165.

${ }^{188}$ Smith, Neil (1984). Uneven Development: Nature, Capital and the Production of Space. Oxford: Basil Blackwell, 84.

${ }^{189}$ Harvey, David (2005). A Brief History of Neoliberalism. New York: Oxford University Press, p. 168.

${ }^{190} \mathrm{Sa}$ 'di, Ahmad H. (1995). "Incorporation without Integration: Palestinian citizens in Israel's labour market," Sociology, 29 (3), p. 432.

${ }^{191}$ Ibid

192 "If surplus labouring population is a necessary product of accumulation or of the development of wealth on a capitalist basis, this surplus population becomes, conversely, the lever of capitalist accumulation, nay, a condition of existence of the capitalist mode of production. It forms a disposable industrial reserve army...it creates, for the changing needs of the self-expansion of capital, a mass of human material always ready for exploitation." Marx, Karl (2000). "Capital Volume 1," in Karl Marx: Selected Writings, ed. by David McLellan. New York: Oxford University Press, p. 517.

${ }^{193}$ Massey, Doreen (1984). Spatial Divisions of Labour: Social structures and the geography of production. London: MacMillan Education Ltd, p. 56.

${ }^{194} \mathrm{Sa}$ 'di, Ahmad H. (1995). "Incorporation without Integration: Palestinian citizens in Israel's labour market," Sociology, 29 (3), p. 433-434.

${ }^{195}$ Smith, Neil (2008). Uneven Development: nature, capital, and the production of space. Athens: University of Georgia Press, p. 141.

${ }^{196}$ Ibid

${ }^{197}$ Salter, Mark B. and Parsons, Nigel. "Israeli Biopolitics: Closure, Territorialization and Governmentality in the Occupied Palestinian Territories." Geopolitics, 2008, 13, p. 706.

${ }^{198}$ Tawil-Souri, Helga (2011). "Qalandia Checkpoint as Space and Nonplace," Space and Culture, 14(1), p. 21.

${ }^{199}$ Massey, 1984; Smith, 1984; Harvey, 1996; Lefebvre, 1992.

${ }^{200}$ Massey, Doreen (1984). Spatial Divisions of Labour: Social structures and the geography of production. London: MacMillan Education Ltd, p. 54.

${ }^{201}$ Vitullo, Anita (2005). "The Long Economic Shadow of the Wall," in Against the Wall: Israel's Barrier to Peace, ed. Michael Sorkin. New York: The New Press, p. 104.

${ }^{202}$ Ibid

203 "Israel to construct barrier along Egyptian border," BBC News, January 11, 2010. Accessed: <http://news.bbc.co.uk/2/hi/middle_east/8451085.stm>.

${ }^{204} \mathrm{Ibid}$

${ }^{205}$ Sadeh, Shuki. "A fence but not a solution on the Israel-Egypt border," Haaretz, Novemeber 25, 2011. Accessed: <http://www.haaretz.com/weekend/week-s-end/a-fence-but-not-a-solution-on-the-israel-egyptborder-1.397627>.

${ }^{206}$ Harvey, David. A Brief History of Neoliberalism. New York: Oxford University Press, 2005, p. 159.

${ }^{207}$ Massey, Doreen (1984). Spatial Divisions of Labour: Social structures and the geography of production. London: MacMillan Education Ltd, p. 68.

${ }^{208}$ US Federal Reserve Chairman Paul Volcker oversaw an increase in interest rates by 21 percent on all US loans, enforcing global economic recession, and coercing various countries, including Mexico, to implement neoliberal reforms.

${ }^{209}$ Harvey, David. A Brief History of Neoliberalism. New York: Oxford University Press, 2005, p. 29. ${ }^{210}$ Ibid

${ }^{211}$ Dunn, Timothy J (1996). The Militarization of the U.S.-Mexico Border, 1978-1992: low-intensity conflict doctrine comes home. Austin: CMAS Books, p. 158.

${ }_{212}^{21}$ Harvey, David. A Brief History of Neoliberalism. New York: Oxford University Press, 2005, p. 77.

${ }^{213}$ Hernandez, Ester and Susan Bibler Coutin (2006). "Remitting subjects: migrants, money and states," Economy and Society, 5(2), p. 201. 
${ }^{214}$ Bandy, Joe (2000). "Bordering the Future: Resisting Neoliberalism in the Borderlands," Critical Sociology, 26(3), p. 232.

${ }^{215}$ Dunn, Timothy J (1996). The Militarization of the U.S.-Mexico Border, 1978-1992: low-intensity conflict doctrine comes home. Austin: CMAS Books, p. 158.

${ }^{216}$ Heyman, Josiah (2010). "US-Mexico border cultures and the challenge of asymmetrical interpenetration," in Ethnographic Approaches to Security, Power, and Identity, ed. Hastings Donnan and Thomas M. Wilson. Lanham: University Press of America, p 27.

${ }^{217}$ Ibid

${ }^{218}$ Dunn, Timothy J (1996). The Militarization of the U.S.-Mexico Border, 1978-1992: low-intensity conflict doctrine comes home. Austin: CMAS Books, p. 157.

${ }^{219}$ Massey, Doreen (1984). Spatial Divisions of Labour: Social structures and the geography of production. London: MacMillan Education Ltd, p. 54.

${ }^{220}$ Smith, Neil (1984). Uneven Development: Nature, Capital and the Production of Space. Oxford: Basil Blackwell, p. 83.

${ }^{221}$ Robinson, William I. (2006). "'Aqui estamos y nos vamos! Global capital and immigrant rights," Race and Class, $48(2)$, p. 83.

${ }^{222}$ Ackleson, Jason (2005). "Constructing Security on the US-Mexico Border," Political Geography, 24(2), p. 171.

${ }^{223}$ Ibid

${ }^{224}$ Tholen, Berry (2010). "The changing border: developments and risks in border control management of Western countries," International Review of Administrative Sciences, 76(2), p 265.

${ }^{225}$ Ackleson, Jason (2005). "Constructing Security on the US-Mexico Border," Political Geography, 24(2), p. 171.

${ }^{226}$ Bennett, Brian. October 22, 2010. "Costly virtual border fence in tatters," Los Angeles Times. Accessed June 12, 2012: <http://articles.latimes.com/2010/oct/22/nation/la-na-invisible-fence-20101022>.

${ }^{227}$ Hall, Stuart (1986). "Gramsci's Relevance for the Study of Race and Ethnicity," Joumal of Communication Inquiry, 10(2), p.18.

${ }^{228}$ Popularly translated as uprising

${ }^{229}$ Usher, Graham (2006). "The wall and the dismemberment of Palestine," Race and Class, 47(3), p. 17.

${ }^{230}$ Foucault, Michel (1979). Discipline and Punish: The Birth of the Prison. New York: Vintage Books, p. 119 .

${ }^{231}$ Usher, Graham (2006). “The wall and the dismemberment of Palestine," Race and Class, 47(3), p. 18.

${ }^{232}$ Ibid

${ }^{233}$ Ibid

${ }^{234}$ Massey, Doreen (1994). Space, Place, and Gender. Minneapolis: University of Minnesota Press, p. 22.

${ }^{235}$ Gramsci, Antonio (1971). Selections from the Prison Notebooks, ed. Quintin, H. and Nowell Smith, G. New York: International Publishers, p. 168.

${ }^{236}$ Ibid, p. 170.

${ }^{237}$ Yiftachel, Oren and Haim Yacobi (2005). "Barriers, Walls and Dialectics: The Shaping of "Creeping Apartheid" in Israel/Palestine," in Against the Wall: Israel's Barrier to Peace, ed. Michael Sorkin. New York: The New Press, p. 142.

${ }^{238}$ Hanafi, Sari (2005). "Spacio-cide and Biopolitics: The Israel Colonial Project from 1947 to the Wall," in Israel/Palestine," in Against the Wall: Israel's Barrier to Peace, ed. Michael Sorkin. New York: The New Press, p. 158.

${ }^{239}$ International Labour Office (2005). "The situation of workers of the occupied Arab territories," International Labour Conference, $93^{\text {rd }}$ session, p.v.

${ }^{240}$ Sayigh, Yezid (2009). "Fixing Broken Windows: Security Reform in Palestine, Lebanon and Yemen. Carnegie Endowment for International Peace, no. 17, p. 5.

${ }^{241}$ Ibid, p. 3.

${ }^{242}$ Hall, Stuart, Chas Critcher, Tony Jefferson, John Clark, and Brian Roberts (1978). Policing the Crisis: Mugging, the state, and law and order. London: MacMillan Press Ltd, p. 201.

${ }^{243}$ Ibid, p. 33. 
${ }^{244}$ Bogard, William (2000). "Smoothing Machines and the Constitution of Society," Cultural Studies, 14(2), p. 273.

${ }^{245}$ Ibid, p. 278.

${ }^{246}$ Ibid, p. 273.

${ }^{247}$ Ibid, p. 274.

${ }^{248}$ A State of Emergency was declared on November 8, 2005, in response to thousands of youth, many of North African descent, rioting in response to the death of two young people at the hands of police. The riots were an expression of oppression experienced by racialized groups in the Paris suburbs.

${ }^{249}$ Hernandez, Marie-Theresa (2010). "The French Banlieue riots of 2005 and their impact on US immigration policy: A transatlantic study," Atlantic Studies, 7(1), p. 79.

${ }^{250}$ Ibid, p. 91.

${ }^{251}$ Bush, George W. January 7, 2004. "President Bush Proposes New Temporary Worker Program: Remarks by the President on Immigration Policy," Office of the Press Secretary. Accessed June 16, 2012: <http://georgewbush-whitehouse.archives.gov/news/releases/2004/01/20040107-3.html>.

${ }^{252}$ Ibid

${ }^{253}$ Odem, Mary E. "Subaltern Immigrants: Undocumented Workers and National Belonging in the United States," Interventions, 10(3), p. 361.

${ }^{254}$ Murphy Efani, Julie A. (2007). "Whose Security? Dilemmas of US Border Security in the ArizonaSenora Borderlands," in Borderlands: Comparing border security in North America and Europe, Ed. Emmanuel Brunet-Jailly. Ottawa: University of Ottawa Press, p. 45.

${ }^{255}$ Odem, Mary E. "Subaltern Immigrants: Undocumented Workers and National Belonging in the United States," Interventions, 10(3), p. 375.

${ }^{256}$ Shantz, Jeff (2010). Racism and Borders: Representation, Repression, Resistance. New York: Algora Publishing, p. 2.

${ }^{257}$ Gramsci, Antonio (1971). Selections from the Prison Notebooks, Ed. Quintin Hoare and Geoffrey Nowell Smith. New York: International Publishers, p. 12.

${ }^{258}$ Moser, Bob (2003). "900 Immigrant Workers take Freedom Ride of their own," Southern Poverty Law Centre, Intelligence Report, Issue 112. Accessed June 16, 2012: <http://www.splcenter.org/getinformed/intelligence-report/browse-all-issues/2003/winter/rough-ride>.

${ }^{259}$ Robinson, William I. (2006). “'Aqui estamos y nos vamos! Global capital and immigrant rights," Race and Class, 48(2), p. 80.

${ }^{260}$ Beirich, Heidi (2012). "Nativist Movement Collapses Amid Infighting," Southern Poverty Law Centre, Intelligence Report, Issue 145. Accessed June 16, 2012: < http://www.splcenter.org/get-

informed/intelligence-report/browse-all-issues/2012/spring/the-year-in-nativism>.

${ }^{261}$ Ibid

${ }^{262}$ Robinson, William I. (2006). “'Aqui estamos y nos vamos! Global capital and immigrant rights," Race and Class, 48(2), p. 80.

${ }^{263}$ Agnew, John and Stuart Corbridge (1995). Mastering Space: Hegemony, territory, and international political economy. New York: Routledge, p. 47.

${ }^{264}$ Agnew, John (2005). Hegemony: The new shape of global power. Philadelphia: Temple University Press, p. 159.

${ }^{265}$ Coleman, M. (2005). "US Statecraft and the US-Mexico border as security/economy nexus," Political Geography, 24(2), p.186.

${ }^{266}$ Shelley, Toby (2007). Exploited: migrant labour in the new global economy. New York: Zed Books Ltd, p. 11.

${ }^{267}$ Yiftachel, Oren and Haim Yacobi (2005). "Barriers, Walls and Dialectics: The Shaping of "Creeping Apartheid" in Israel/Palestine," in Against the Wall: Israel's Barrier to Peace, ed. Michael Sorkin. New York: The New Press, p. 139.

${ }^{268}$ Ibid, p. 141.

${ }^{269}$ Bogard, William (2000). "Smoothing Machines and the Constitution of Society," Cultural Studies, 14(2), p. 287. 
${ }^{270}$ Alatout, Samer (2009). "Walls as Technologies of Government: The Double Construction of Geographies of Peace and Conflict in Israeli Politics, 2002-Present," Annals of the Association of American Geographers, 99(5), p. 963.

${ }^{271}$ Tawil-Souri, Helga (2009). "New Palestinian centers: An ethnography of the "checkpoint economy." International Journal of Cultural Studies. Vol. 12 (3), p. 230.

${ }^{272}$ Ibid, p. 232.

${ }^{273}$ Bogard, William (2000). "Smoothing Machines and the Constitution of Society," Cultural Studies, $14(2)$, p. 275.

${ }^{274}$ Robinson, William I. (2006). “'Aqui estamos y nos vamos! Global capital and immigrant rights,” Race and Class, 48(2), p. 78.

${ }^{275}$ Ibid

${ }^{276}$ Ibid

${ }^{277}$ Ibid

${ }^{278}$ Smith, Neil (1984). Uneven Development: Nature, Capital and the Production of Space. Oxford: Basil Blackwell, p. 90.

${ }^{279}$ In 1975, California adopted the Agricultural Labour Relations Act, largely as a result of the effective organizing done by the UFW, which led to greater rights for farm workers.

${ }^{280}$ In 1981, the legislative director of the UFW, Stephanie Bower, called for fines against employers that hired undocumented migrants, echoing the position of the AFL-ClO.

${ }^{281}$ Milkman, Ruth (2011). "Immigrant Workers, Precarious Work, and the US Labour Movement," Globalizations, 8(3), p. 363.

${ }^{282}$ The American Federation of Labour and Congress of Industrial Organizations

${ }^{283}$ Milkman, Ruth (2011). "Immigrant Workers, Precarious Work, and the US Labour Movement," Globalizations, 8(3), p. 363.

${ }^{284}$ Robinson, William I. (2006). "'Aqui estamos y nos vamos! Global capital and immigrant rights," Race and Class, 48(2), p. 88.

${ }^{285}$ Bandy, Joe (2000). "Bordering the Future: Resisting Neoliberalism in the Borderlands," Critical Sociology, 26(3), p. 254.

${ }^{286}$ Ibid

${ }^{287}$ US Customs and Border Protection. "About CBP: Border Security," Department of Homeland Security. Accessed May 28, 2012. < http://www.cbp.gov/xp/cgov/about/>. 


\section{Bibliography}

Agnew, John and Stuart Corbridge (1995). Mastering Space: Hegemony, territory, and international political economy. New York: Routledge.

Agnew, John (2005). Hegemony: The new shape of global power. Philadelphia: Temple University Press.

Akleson, Jason (2005). "Constructing security on the U.S.-Mexico Border," Political Geography, 24 (2).

Alatout, Samer (2009). "Walls as Technologies of Government: The Double Construction of Geographies of Peace and Conflict in Israeli Politics, 2002-Present," Annals of the Association of American Geographers, 99(5).

Anzaldua, Gloria (2007). Borderlands: La Frontera. San Francisco: Aunt Lute Books.

BBC News. "Israel to construct barrier along Egyptian border," January 11, 2010. Accessed: <http://news.bbc.co.uk/2/hi/middle_east/8451085.stm>.

Beirich, Heidi (2012). "Nativist Movement Collapses Amid Infighting," Southern Poverty Law Centre, Intelligence Report, Issue 145. Accessed June 16, 2012: $<$ http://www.splcenter.org/get-informed/intelligence-report/browse-allissues/2012/spring/the-year-in-nativism>.

Bogard, William (2000). "Smoothing Machines and the Constitution of Society," Cultural Studies, 14(2).

Bornstein, Avram S (2002). "Borders and the Utility of Violence: State Effects on the 'Superexploitation' of West Bank Palestinians," Critique of Anthropology, 22(2).

Bandy, Joe (2000). "Bordering the Future: Resisting Neoliberalism in the Borderlands," Critical Sociology, 26(3).

Bennett, Brian. October 22, 2010. "Costly virtual border fence in tatters," Los Angeles Times. Accessed June 12, 2012: <http://articles.latimes.com/2010/oct/22/nation/lana-invisible-fence-20101022>.

Brown, Wendy (2010). Walled States, Waning Sovereignty, New York: Zone Books.

Brunet-Jailly, Emmanuel (2007). Borderlands: Comparing Border Security in North America and Europe. Ottawa: University of Ottawa Press.

Bush, George W. "President Bush Proposes New Temporary Worker Program: Remarks by the President on Immigration Policy," Office of the Press Secretary, January 7, 
2004. Accessed: <http://georgewbush-

whitehouse.archives.gov/news/releases/2004/01/20040107-3.html>.

Calavita, Kitty (1995). "Mexican Immigration to the USA: the contradictions of border control," in The Cambridge Survey of World Migration, ed. Robin Cohen. Cambridge: Press Syndicate of the University of Cambridge.

CBC News. "Olympic Security Estimated to Cost 900 Million," February 19, 2009. Accessed: <http://www.cbc.ca/news/canada/british-columbia/story/2009/02/19/bcolympics-cost-colin-hansen.html>.

Central Bureau of Statistics (2011). "Israel in Figures: 2011," State of Israel, p. 17. Accessed: <http://www1.cbs.gov.il/www/publications/isr_in_n1le.pdf>.

Cohen, Yinon (2009). "Israel: the demographic and economic dimension of migration," in CARIM Mediterranean Migration Report 2008-2009, ed. Philippe Fargue, Robert Schuman Centre for Advanced Studies, San Domenico di Fiesole, European University Institute.

Coleman, Matthew (2005). "US Statecraft and the US-Mexico border as security/economy nexus," Political Geography, 24(2).

Consulate General of the United States. "H2 Visas: temporary laborers." The U.S. Department of State. Accessed May 29, 2012:

$<$ http://monterrey.usconsulate.gov/h2_visa.html>.

Correia, David (2009). "Making destiny manifest: United States territorial expansion and the dispossession of two Mexican property claims in New Mexico, 1824-1899," Journal of Historical Geography, (35)1.

Coutin, Susan Bibler (2010). "Confined within: National territories as zones of confinement,” Political Geography, 29(4).

Dalby Simon, (1991). "Critical geopolitics: discourse, difference, and dissent," Environment and Planning D: Society and Space, 9(3).

Davis, Mike (2005). "The Great Wall of Capital," in Against the Wall, ed. Michael Sorkin. New York: The New Press.

Dunn, Timothy J (1996). The Militarization of the U.S.-Mexico Border, 1978-1992: lowintensity conflict doctrine comes home. Austin: CMAS Books.

Dunn, Timothy and Joseph Nevins (2008). "Barricading the Border," NACLA Report on the Americas, 41(6). 
Farsakh, Lelia (2005). Palestinian Labour Migration to Israel: Labour, land, and occupation. New York: Routledge.

Foucault, Michel (1979). Discipline and Punish: The Birth of the Prison. New York: Vintage Books.

Foucault, Michel (1980). Power/Knowledge: Selected Interviews and Other Writings 1972-1977. New York: Pantheon Books.

Foucault, Michel (1997). "Society Must be Defended." New York: Picador.

Foucault, Michel (2007). Security, Territory, Population. New York: Palgrave Macmillan.

Garcia, Michael John and Blas Nunez-Neto (2007). "Border Security: The San Diego Fence." Library of Congress Washington DC Congressional Research Service, p. 2. Accessed June 21, 2012: <http://handle.dtic.mil/100.2/ADA469083>.

Gardner II, Trevor and Aarti Kohli (2009). "The CAP Effect: Racial Profiling in the ICE Criminal Alien Program," The Chief Justice Earl Warren Institute on Race, Ethnicity and Diversity, University of California Berkley Law School, p. 3. Accessed: <http://www.law.berkeley.edu/files/policybrief_irving_0909_v9.pdf > .

Goldring, Luin; Berinstein, Carolina; and Bernhard, Judith (2007). "Institutionalizing Precarious Immigration Status in Canada," Early Childhood Education Publications and Research. Paper 4, p. 6. Accessed: $<$ http://digitalcommons.ryerson.ca/ece/4>.

Gomez, Laura E. (2007). Manifest Destinies: the making of the Mexican American Race. New York: New York University Press.

Gramsci, Antonio (1971). Selections from the Prison Notebooks, ed. Quintin Hoare and Geoffrey Nowell Smith. New York: International Publishers.

Griswold del Castillo, Richard (1990). The Treaty of Guadalupe Hidalgo: A Legacy of Conflict. London: University of Oklahoma Press.

Hall, Stuart, Chas Critcher, Tony Jefferson, John Clark, and Brian Roberts (1978). Policing the Crisis: Mugging, the state, and law and order. London: MacMillan Press Ltd.

Hall, Stuart (1986). "Gramsci's Relevance for the Study of Race and Ethnicity," Journal of Communication Inquiry, 10(2). 
Hanafi, Sari (2005). "Spacio-cide and Biopolitics: The Israel Colonial Project from 1947 to the Wall," in Israel/Palestine," in Against the Wall: Israel's Barrier to Peace, ed. Michael Sorkin. New York: The New Press.

Harvey, David. A Brief History of Neoliberalism. New York: Oxford University Press, 2005.

Hernandez, Ester and Susan Bibler Coutin (2006). "Remitting subjects: migrants, money and states," Economy and Society, 5(2).

Hernandez, Marie-Theresa (2010). "The French Banlieue riots of 2005 and their impact on US immigration policy: A transatlantic study," Atlantic Studies, 7(1).

Hernandez, Sonia (2001). "The Legacy of the Treaty of Guadalupe Hidalgo on Tejanos' Land," Journal of Popular Culture, 35(2).

Heyman, Josiah (1998). "State effects on labour exploitation: the INS and undocumented immigrants at the Mexico-United States border." Critique of Anthropology, 18(2).

Heyman, Josiah McC. (2010). "US-Mexico border cultures and the challenge of asymmetrical interpenetration," in Ethnographic Approaches to Security, Power, and Identity, Ed. Hastings Donnan and Thomas M. Wilson. Lanham: University Press of America.

International Labour Office (2005). "The situation of workers of the occupied Arab territories," International Labour Conference, $93^{\text {rd }}$ session, p. v.

Israel Law Resource Centre (2007). Nationality Law of 1952, Section 2(a). State of Israel. Accessed:

$<$ http://www.israellawresourcecenter.org/israellaws/fulltext/nationalitylaw.htm>.

Johnson, Benjamin (2004). "The Plan de San Diego Uprising and the Making of the Texas-Mexican Borderlands," in Continental Crossroads: Remapping US-Mexico Borderlands History, eds. Samuel Truett and Elliott Young. London: Duke University Press.

Limerick, Patricia Nelson (1987). The Legacy of Conquest. New York: Norton.

Lis, Jonathan. "Bill giving priority to ex-soldiers ruled unconstitutional: proposed law pits Attorney general vs. Yisrael Beiteinu party." Haaretz. June 17, 2011. Accessed: <http://www.haaretz.com/print-edition/news/bill-giving-priority-to-exsoldiers-ruled-unconstitutional-1.368129>.

Marchand, Marianne H (2008). "The Violence of Development and the Migration/Insecurities Nexus: labour migration in a North American context," Third World Quarterly, 29(7). 
Marx, Karl and Fredrich Engels (1994). "The Communist Manifesto," in Karl Marx: Selected Writings, ed. Lawrence H. Simon. Cambridge: Hackett Publishing Company Inc.

Marx, Karl (1994). "Preface to A Contribution to the Critique of Political Economy," in Karl Marx: Selected Writings. Ed. Lawrence H. Simon. Cambridge: Hackett Publishing Company Inc.

Marx, Karl (2000). "Capital Volume 1," in Karl Marx: Selected Writings, ed. by David McLellan. New York: Oxford University Press.

Marx, Karl (2000). "Grundrisse," in Karl Marx: Selected Writings, ed. David McLellan. New York: Oxford University Press.

Marx, Karl (2000). "Economic and Philosophical Manuscripts," in Karl Marx: Selected Writings, ed. by David McLellan. New York: Oxford University Press.

Massey, Doreen (1984). Spatial Divisions of Labour: Social structures and the geography of production. London: MacMillan Education Ltd.

Massey, Doreen (1994). Space, Place, and Gender. Minneapolis: University of Minnesota Press.

Miles, Robert and Malcolm Brown (2003). Racism: Second Edition. London: Routledge.

Milkman, Ruth (2011). "Immigrant Workers, Precarious Work, and the US Labour Movement," Globalizations, 8(3).

Moser, Bob (2003). "900 Immigrant Workers take Freedom Ride of their own," Southern Poverty Law Centre, Intelligence Report, Issue 112. Accessed: $<$ http://www.splcenter.org/get-informed/intelligence-report/browse-allissues/2003/winter/rough-ride>.

Murphy Efani, Julie A. (2007). "Whose Security? Dilemmas of US Border Security in the Arizona-Senora Borderlands," in Borderlands: Comparing border security in North America and Europe, Ed. Emmanuel Brunet-Jailly. Ottawa: University of Ottawa Press.

Mykkanen, Juri (1994). “To methodize and regulate them: Petty's governmental science of statistics," History of the Human Sciences, 7(3).

Neocleous, Mark (2011). "Security as Pacification," in Anti-Security, eds. Mark Neocleous and George S. Rigakos. Ottawa: Red Quill Books Ltd. 
Odem, Mary E. "Subaltern Immigrants: Undocumented Workers and National Belonging in the United States," Interventions, 10(3).

O Tuathail, Gearoid, Dalby, Simon and Paul Routledge (1997). The Geopolitics Reader. New York: Routledge.

Petty, William. "The Petty Papers," In A General Police System: Political Economy and Security in the Age of Enlightenment, ed. George S. Rigakos, John L. McMullan, Joshua Johnson, and Gulden Ozcan. Ottawa: Red Quill Books Ltd, 2009.

Public Papers of the Presidents of the United States: George W. Bush (2006, Book I). United States Government Printing Office. Accessed June 10, 2012: $<$ http://www.gpo.gov/fdsys/pkg/PPP-2006-book1/html/PPP-2006-book1-docpg559.htm>.

Ravid, Barak. "Netanyahu orders swift deportation of 25,000 illegal African migrants," in Hareetz. June 4, 2012. Accessed: <http://www.haaretz.com/news/diplomacydefense/netanyahu-orders-swift-deportation-of-25-000-illegal-african-migrants$1.434190>$.

Rigakos, George (2005). "Beyond Public-Private: Towards a New Typology in Policing," in Re-imaging Policing in Canada, ed. Dennis Cooley. Toronto: University of Toronto Press.

Rigakos, George S. (2011). "To extend the scope of productive labour”: Pacification as police project," in Anti-Security, ed. Mark Neocleous and George S. Rigakos. Ottawa: Red Quill Books Ltd.

Robinson, William I. (2006). “'Aqui estamos y nos vamos! Global capital and immigrant rights," Race and Class, 48(2).

Rose, William (2002). "Crimes of Color: Risk, Profiling, and the Contemporary Racialization of Social Control," Journal of Politics, Culture and Society, 16(2).

Rosenhek, Zeev (2003). "The Political Dynamics of a Segmented Labour Market: Palestinian Citizens, Palestinians from the Occupied Territories and Migrant Workers in Israel," Acta Sociologica, 46(3).

Sadeh, Shuki. "A fence but not a solution on the Israel-Egypt border," Haaretz, Novemeber 25, 2011. Accessed: <http://www.haaretz.com/weekend/week-s-end/afence-but-not-a-solution-on-the-israel-egypt-border-1.397627>.

Sa'di, Ahmad H. (1995). "Incorporation without Integration: Palestinian citizens in Israel's labour market," Sociology, 29 (3). 
Saldaña-Portillo, María Josefina (2004). "“Wavering on the Horizon of Social Being': The Treaty of Guadalupe-Hidalg and The Legacy of its Racial Character in Americo Paredes's George Washington Gomez," Radical History Review, (89) Spring.

Salter, Mark B. and Parsons, Nigel (2008). "Israeli Biopolitics: Closure, Territorialization and Governmentality in the Occupied Palestinian Territories." Geopolitics, 13(4).

Sayigh, Yezid (2009). "Fixing Broken Windows: Security Reform in Palestine, Lebanon and Yemen," Carnegie Endowment for International Peace, no. 17.

Shantz, Jeff (2010). Racism and Borders: Representation, Repression, Resistance. New York: Algora Publishing.

Shapiro, Michael, J (1997). "Narrating the Nation, Unwelcoming the Stranger: AntiImmigration Policy in Contemporary "America." Alternatives, 22(1).

Shelley, Toby (2007). Exploited: migrant labour in the new global economy. New York: Zed Books Ltd.

Smith, Neil (2008). Uneven Development: Nature, capital, and the production of space. Athens: University of Georgia Press.

"Snapshot: A summary of CBP facts and figures." US Customs and Border Protection, February 2012. Accessed May 28, 2012:

<http://www.cbp.gov/linkhandler/cgov/about/accomplish/cbp_snapshot.ctt/snapsho t.pdf $>$

Tawil-Souri, Helga (2009). "New Palestinian centers: An ethnography of the 'checkpoint economy." International Journal of Cultural Studies, 12(3).

Tawil-Souri, Helga (2011). "Qalandia Checkpoint as Space and Nonplace," Space and Culture, 14(1).

Taylor, Edward J (2010). "Agricultural Labour and Migration Policy," The Annual Review of Resource Economics, Vol. 2.

Tholen, Berry (2010). "The changing border: developments and risks in border control management of Western countries," International Review of Administrative Sciences, 76(2).

Trigueros-Legarreta, Paz (2012). "The Vulnerability of Mexican Temporary Foreign Workers in the United States with H-2 Visas," in Migration and Remittances From Mexico: Trends, Impacts, and New Challenges, ed. Alfredo Cuechecha and Carla Pederzini. Plymouth: Lexington Books. 
United Nations Office for the Coordination of Humanitarian Affairs, occupied Palestinian territory (2010). "West Bank Movement and Access," p. 2. Accessed:

<http://www.ochaopt.org/documents/ocha_opt_movement_access_2010_06_16_en glish.pdf>.

US Customs and Border Protection. "About CBP: Border Security,". Department of Homeland Security. Accessed May 28, 2012:

$<$ http://www.cbp.gov/xp/cgov/about/>.

Usher, Graham (2006). "The wall and the dismemberment of Palestine," Race and Class, 47(3).

Vitullo, Anita (2005). "The Long Economic Shadow of the Wall," in Against the Wall: Israel's Barrier to Peace, ed. Michael Sorkin. New York: The New Press.

Weizman, Eyal (2007). Hallow Land: Israel's Architecture of Occupation. New York: Verso.

Yiftachel, Oren and Haim Yacobi (2005). "Barriers, Walls and Dialectics: The Shaping of "Creeping Apartheid" in Israel/Palestine," in Against the Wall: Israel's Barrier to Peace, ed. Michael Sorkin. New York: The New Press. 